

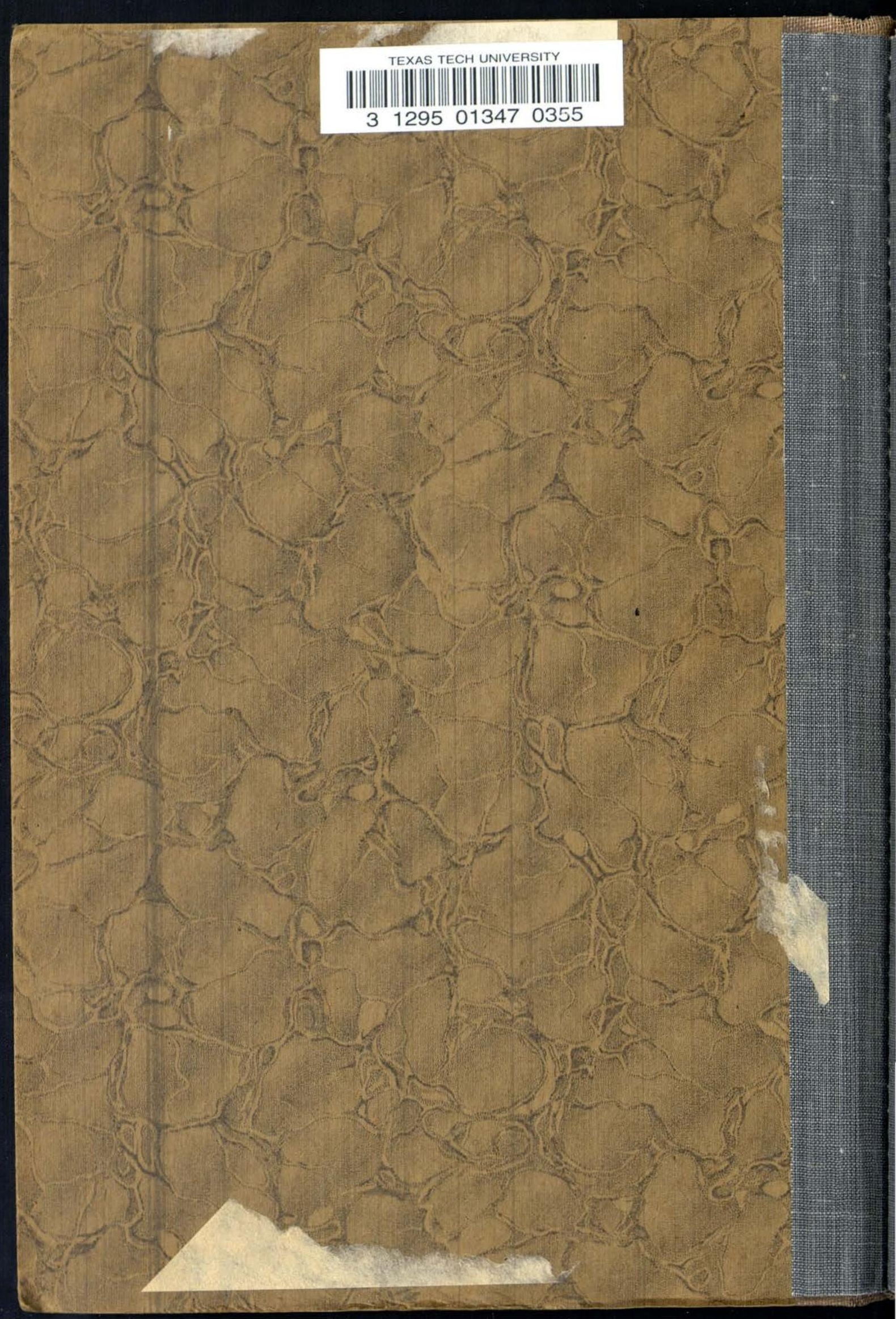




\section{$A D D-98544_{0}^{\circ}$}

DEPARTMENT OF THE INTERIOR

UNITED STATES GEOLOGICAL SURVE்Y

GEORGE OTIS SMITH, DIRECTOR

BULLETIN 439

THE

\section{FAUNA OF THE MOOREFIELD SHALE \\ OF ARKANSAS}

BY

GEORGE H. GIRTY

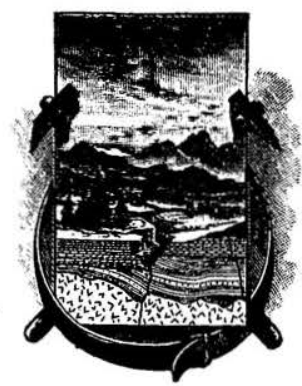

WASHINGTON

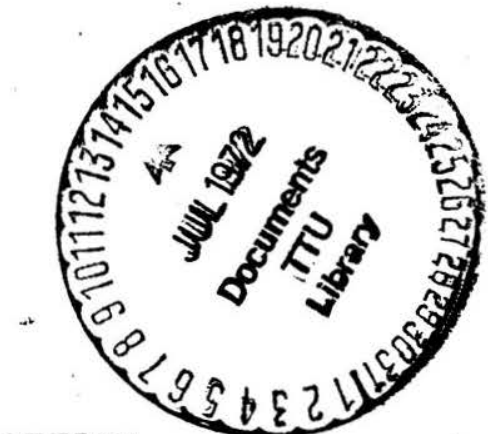

GOVERNMENT PRINTING OFFIOE 



\section{CONTENTS.}

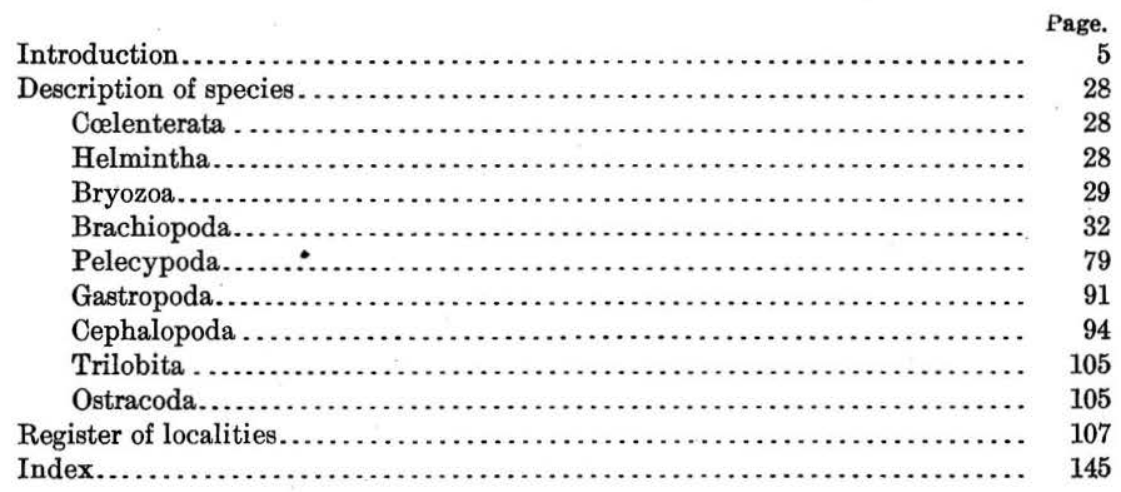

\section{ILLUSTRATIONS.}

Pages.

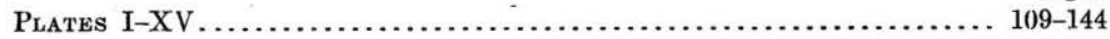





\title{
THE FAUNA OF THE MOOREFIELD SHALE OF ARKANSAS.
}

\author{
By George H. Girty.
}

\section{INTRODUCTION.}

The section of Mississippian rocks in northern Arkansas includes a bed of black shale which is of considerable interest, both for the fauna it contains and the vicissitudes of nomenclature it has undergone. It is inclosed between two limestone formations known as the Boone and the Pitkin. The sections involving these formations have been especially studied at opposite ends of the line of outcrop-at Batesville, in northeastern Arkansas, and at Fayetteville, in northwestern Arkansas-and it is owing to this circumstance, coupled with imperfect knowledge of the geology of the intervening area, that most of the intricacy of nomenclature has arisen.

In the Fayetteville region, between the black shale and the Boone formation, a thin and discontinuous sandstone occurs. Toward the upper limit of the shale, just below the Pitkin limestone or separated from it by shaly beds measuring up to 60 feet, there is another rather thick sandstone, which also is not persistent. Simonds, ${ }^{a}$ who named the formations in the Fayetteville region, called the lower sandstone the Wyman sandstone, the lower shale the Fayetteville shale, and the upper sandstone and shale the Batesville sandstone and Marshall shale, respectively, these names having been imported from the Batesville region.

In the vicinity of Batesville the black shale is divided about midway by a massive quartz sandstone from 30 to nearly 200 feet in thickness. The formations in this region were called by Penrose in $1891,{ }^{b}$ in ascending order, the Fayetteville shale, the Batesville sandstone, and the Marshall shale. Of these names the first was, of course, taken from the Fayetteville region, the second from Batesville itself, and the third from Marshall, a village intermediate between Batesville and Fayetteville.

Although the Arkansas geologists evidently recognized the general equivalence of these beds, they were apparently at fault in correlating

$a$ Simonds, F. W., Ann. Rept. Geol. Survey Arkansas for 1888, vol. 4, 1891, pp. xili et seq.

b Penrose, R. A. F., jr., Ann. Rept. Geol. Survey Arkansas for 1890, vol. 1, 1891, pp. 138 et seq. 
them in detail, for, according to Adams and Ulrich, ${ }^{a}$ the Batesville sandstone is not equivalent to the upper sandstone of the Fayetteville region, as Simonds supposed, but to the lower.

The equivalence of the formations in the two sections is now readily determined from the literature, but the proper nomenclature to be used is a more difficult question. It is complicated by the fact that Simonds's report, which, as already recounted, carries over into the Fayetteville region some of the formations of the Batesville section and correlates them wrongly there, was published before Penrose's account of the Batesville section itself. Now there may readily be opposing views as to whether the two formations, Batesville sandstone and Marshall shale, which Simonds describes in an alien section and under a misapprehension as to their geologic relations, can be considered as properly established in his report. I am rather inclined to the view that they should not be considered established at all until the publication by Penrose in 1891 of the report from which the names were evidently taken. It is clear, however, that these two names must be regarded as established or not established in Simonds's report. If the term Batesville sandstone was not established until Penrose's report was published, then it is evident that the names Wyman and Fayetteville have priority over Batesville and Fayetteville, which Adams and Ulrich adopted for the same formations. If the two terms are regarded as having been established in Simonds's report, the question immediately presents itself, Shall they be held to apply to the formations at Batesville and Marshall, for which the names we know were really intended, or to the formations in the Fayetteville region, with which, in their borrowed usage, they were first associated? According to the latter opinion, with which I do not agree, the terms Marshall and Batesville would apply to the formations which Adams and Ulrich called Fayetteville (in part) and Wedington, the latter being considered a member of the Fayetteville formation. If, however, the names were regarded as fixed to the formations at the locality from which they were derived, the two terms would supersede the names Batesville and Fayetteville employed by Adams and Ulrich. In other words, by priority, if Batesville supersedes Wyman, then Marshall should supersede Fayetteville, while if Fayetteville supersedes Marshall, then Wyman should be employed instead of Batesville. It must be that Fayetteville and Batesville were adopted by these authors, in spite of the inconsistency involved, because of the currency which the terms had received over Wyman and Marshall, a fact which, all things considered, probably justifies their adoption. 
Adams and Ulrich thus use Batesville for the lower sandstone in the Fayetteville section which Simonds had named Wyman, and Fayetteville for the rest of the series up to the Pitkin (Simonds's Archimedes limestone), including therein the formations which Simonds had called Fayetteville shale, Batesville sandstone, and Marshall shale. His Batesville sandstone, left anonymous by correlating the true Batesville with the lower sandstone at Fayetteville rather than with the upper, they named the Wedington, considering it a member of the Fayetteville formation. In the Batesville region the name Batesville is, of course, retained, and since by the correlation of these authors the black shale above rather than that below the Batesville sandstone is equivalent to the Fayetteville shale, the latter term is substituted for the term Marshall. The black shale underlying the Batesville, therefore, which Penrose had called Fayetteville shale, by this correlation became nameless, and the authors mentioned proposed the name Moorefield shale, from a village near Batesville where the beds are well exposed. Since fossils were (erroneously) stated to be rare in the typical Fayetteville shale while they were abundant in the Moorefield, Prof. H. S. Williams suspected that the latter was not the same as the Fayetteville, and, wishing to give it a distinctive name on account of the interesting fauna it contained, had meanwhile introduced the name "Spring Creek limestone" for part of the beds which were later called Moorefield. But the name Spring Creek had already been preoccupied for a formation in Texas. The Arkansas beds, however, had received such prominence through the writings of Williams and others that in this case, as in that of the Batesville sandstone, the law of priority might, it seems to me, have advantageously been disregarded. The accompanying table will help to elucidate the nomenclature involved.

Correlation of formations in northern Arkansas.

\begin{tabular}{|c|c|c|c|}
\hline $\begin{array}{l}\text { W. Simonds, } 1891 \\
\text { (Ann. Rept. Arkansas } \\
\text { Geol. Survey for 1888, } \\
\text { vol. 4, p. xlii), Wash- } \\
\text { ington County (Fay- } \\
\text { etteville). }\end{array}$ & $\begin{array}{l}\text { R. A. F. Penrose, } 1891 \\
\text { (Ann. Rept. Arkansas } \\
\text { Geol. Survey for 1890, } \\
\text { vol. 1, p. 113), Bates- } \\
\text { ville region. }\end{array}$ & $\begin{array}{l}\text { H. S. Williams, } 1895 \\
\text { (Am. Jour. Sci., 3d } \\
\text { ser., vol.49, pp. 94-96), } \\
\text { Batesville district. }\end{array}$ & $\begin{array}{l}\text { S. Weller, } 1897 \text { (Trans. } \\
\text { New York Acad. Sci., } \\
\text { vol. 16, pp. 278-282), } \\
\text { Batesville region. }\end{array}$ \\
\hline $\begin{array}{l}\text { Archimedes limestone..... } \\
\text { Marshall shale } \ldots . . . . . . . . \\
\text { Batesville sandstone...... } \\
\text { Fayetteville shale......... } \\
\text { Wyman sandstone....... }\end{array}$ & $\begin{array}{l}\text { Marshall shale } \ldots . . . . . . \\
\text { Batesville sandstone.... } \\
\text { Fayetteville shale...... } \\
\text { Boone chert............... }\end{array}$ & $\begin{array}{l}\text { Batesville sandstone..... } \\
\text { Spring Creek limestone= } \\
\text { Fayetteville shales to } \\
\text { the west. } \\
\text { Boone chert.............. }\end{array}$ & $\begin{array}{l}\text { Batesville sandstone. } \\
\text { Spring Creek limestone } \\
\text { and } \mathrm{sh} \text { al } \mathrm{e}=\text { Fayette- } \\
\text { ville shales of Arkansas } \\
\text { geologists. } \\
\text { Boone chert. }\end{array}$ \\
\hline
\end{tabular}


Correlation of formations in northern Arkansas-Continued.

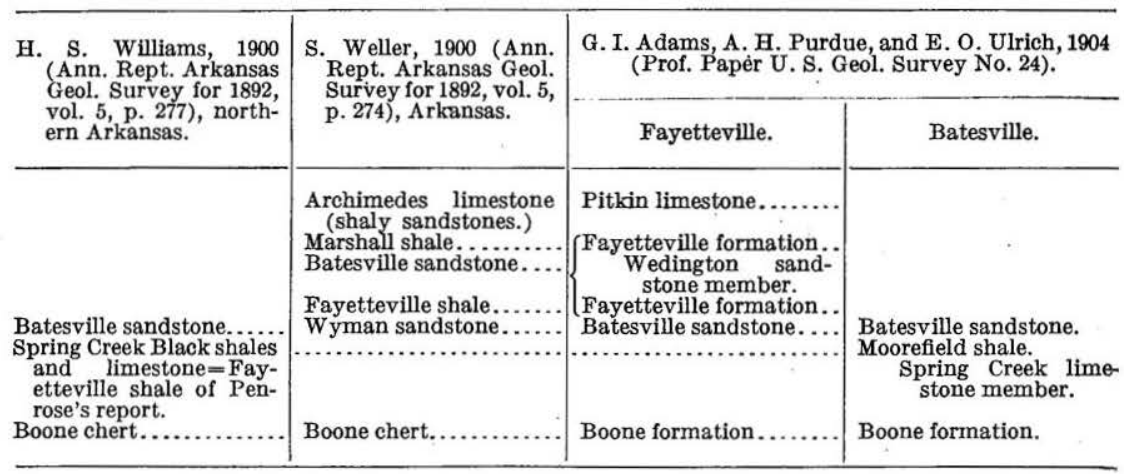

According to Adams and Ulrich, therefore, the Moorefield shale, with the fauna of which this paper is concerned, comprises the beds in the Batesville region that lie between the Boone and the Batesville sandstone. It thins out. to the west so that at Fayetteville the Batesville rests directly upon the Boone without any Moorefield intervening between them at all. The Batesville and underlying Moorefield can be identified with some certainty at Marshall, a locality which has already been mentioned, but I do not know that the Moorefield has been recognized in sections farther west, though we must presume that it extends in that direction beyond Marshall. At all events the collections which I have studied are restricted to the two localities mentioned, Batesville and Marshall, though the Batesville collections themselves comprise three distinct stations-Spring Creek, west of Batesville; Moorefield, east of Batesville; and Howards Wells, northeast of Batesville and Moorefield.

Although the Moorefield shale received its name from Moorefield, and although it there contains the interesting goniatites which Prof. J.P. Smith ${ }^{a}$ has described, thereby bringing the locality into more or less prominence, the outcrops along Spring Creek, which gave name to the "Spring Creek limestone," will probably always be the classic locality for the formation, at least from a paleontologist's standpoint, for there the peculiar and characteristic fauna of the formation was first found and is best developed. For this reason I shall often, in the present paper, have occasion to refer to this calcareous phase of the basal portion of the Moorefield shale outcropping along Spring Creek, or to the fauna which occurs in it, and for the sake of brevity and precision I shall use Williams's term "Spring Creek limestone". to designate it. At the same time it is doubtful whether this group of rocks, geologically unimportant and possibly of no great areal extent, deserves a distinguishing name, or, on the other 
hand, whether "Spring Creek" could advantageously be retained for it.

The main track of the White River branch of the St. Louis, Iron Mountain and Southern Railway now goes through Batesville and up White River into Missouri. About 2 miles west of Batesville it sends off a branch which passes to the northwest up Spring Creek, a tributary of White River, to Cushman. The point of division, represented merely by a switch, is known as White River Junction. The typical outcrop of the "Spring Creek limestone" seems to be about half a mile northwest of White River Junction, where some outcrops and cuttings on the bank of Spring Creek expose the beds along the railroad. This point is a few rods south of the intersection of the railroad and wagon road, as represented on the map of the Batesville quadrangle, the rails passing over the road on a short trestle. At this point, also, on Spring Creek, is Ruddell's mill.

The detailed section at Spring Creek made by Weller was published by Williams in 1900 . It is as follows: ${ }^{a}$

Section (locality 1248A) in the railroad cut east of the trestle over the wagon road, near White River Junction, Ark.

A13. A fine-grained grit runs down into A12 in several places and is decomposed. (This may be the upper termination of the limestone where it underlies the Batesville sandstone, which is said by Doctor Penrose to overlie the Fayetteville shale.) $b$

A12. Black limestone, generally solid, heavy bedded, in some places quite shaly, varies greatly. The lower 3 inches contain fossils, and fossils also occur higher up in bands and pockets .................... 8

A11. Brown shale, few fossils...................................

A10. Black limestone, hard, no fossils.......................... 2

A9. Brown shale, no fossils................................... 4

A8. Black limestone, hard, no fossils............................. 6

A7. Black shale, becoming brown at top, no fossils.................. 10

A6. Black limestone, hard, fossils abundant, weathers like A5 ........... 1

A5. Brown gritty shale, many fossils............................. 6

A4. Soft yellow shale, almost decomposed to clay, no fossils ............ $6-24$

A3. Black limestone, hard, no fossils .......................... 12-18

A2. Brown gritty shale, many fossils........................... 6

A1. Black shaly limestone, many fossils.

This section aggregates less than 18 feet, exclusive of two beds whose thickness is not given. It is suggested that the upper portion of this series grades into the Batesville sandstone. This I believe to be a mistake. ${ }^{c}$ It has been stated by Williams that the outcrop at Spring Creek is complicated by faulting. I did not examine the Spring Creek outcrops at all points and am not prepared to say that

a Branner, J. C., Ann. Rept. Geol. Survey Arkansas for 1892, vol. 5, 1900, p. 342.

b Ann. Rept. Geol. Survey Arkansas for 1890, vol. 1, 1891, p. 139.

$c$ In a letter to Professor Williams, Mr. Weller suggests that this sandstone is merely a weathered phase of the impure siliceous limestone, an explanation which is probably the correct one. 
faulting does not occur there. In fact, it is evident that the beds are tilted and disturbed, but I saw no evidence of faulting in the territory I examined, and I believe that a series of argillaceous beds succeeds the calcareous sediments described in detail by Weller and intervenes between them and the Batesville sandstone. Above the "Spring Creek limestone" there may be in fact as much as 150 feet of black shale of the Moorefield formation before the Batesville is reached.

My own observations on the exposures in this region may be summarized as follows. About 300 paces northwest of the trestle over the wagon road there are exposed about 20 feet of massive, fine, whitish limestone overlain by about 20 feet of cherty limestone in thin beds. These strata, which without much question belong to the Boone formation, by reason of their dip gradually pass below the level of the track in going toward White River Junction. This occurs about 140 paces from the trestle. From this point onward for a considerable distance there are few and poor exposures, thin cherty bands, and a few ledges of limestone. Just northwest of the trestle 5 feet of limestone interstratified with thin cherty sheets was noticed. About 140 paces southeast of the trestle the outcrops of the "Spring Creek limestone" come in, extending in low, poor exposures for about 117 paces.

The beds were not so well shown at the time of my visit as when Weller examined them sixteen years previously, and it was not possible to give so accurate an account of them. I estimated the thickness of the "Spring Creek limestone" at 12 feet, as follows:

$$
\text { Section of the "Spring Creek limestone," Arkansas. }
$$

The upper limestone, fine-grained, and light to dark gray in color, and containing no fossils but lingulas ................................ 8

Separated probably by thin shales from an earthy limestone about.......... 1 Below which the rocks are mostly concealed but appear to consist of thin black shale and fine black limestone, about.......................... 3

It is evident by comparing Mr. Weller's section with these notes that when his observations were made there was exposed to view about 6 feet of the lower part of the "Spring Creek beds" which was concealed at the time of my visit.

From the end of this outcrop, nearly 257 paces southeast of the trestle, no exposures were noted for a long distance (580 paces), ${ }^{a}$ but at that point one may observe in going up the hillside from the track level 60 feet of greenish and black shales in alternating bands, sandy below but finer and more fissile above. For 80 feet above these

a It is doubtless in this interval that the reported fault occurs. As already noted, I saw no evidences of a fault from the railroad track and did not go back on the hill to search for it. 
shales the rocks are largely concealed to the top of the bill, where 3 feet of Batesville sandstone is exposed in place. A poor outcrop of greenish shale occurs near the top of the interval not far below the sandstone.

I am disposed to believe that these outcrops from the Boone up imperfectly represent a single, simple, continuous series. The last exposures are in a continuous section and can not be complicated by faulting. They-represent the Batesville sandstone and underlying beds rather than a shale and second sandstone above the Batesville (which, according to Williams's suggestion, would come in immediately over the "Spring Creek limestone"), because the black shales above the Batesville are elsewhere succeeded by a heavy limestone series without any sandstone for a long distance; because the sandstone here carries the Batesville fauna; and because this sequence is found in sections in which no one has thought to suggest displacements. If the Batesville rests upon the "Spring Creek limestone" at Ruddell's mill, as suggested by Williams, and in this section is separated by 140 feet of shales or more, the sedimentation has changed very rapidly indeed in so short a distance.

No evidence of faulting was seen by me along this course, and if the sequence of beds is continuous it is probably safe to add 50 feet, or possibly more, to the 140 feet of shale exposed in the hillside to represent the long interval southeast of the Spring Creek outcrops in which no exposure was seen. The interval by which the Batesville sandstone is separated from the Boone formation at this point I would estimate as about 225 feet.

The hillside exposure just described is only about 200 paces from White River Junction. The Batesville dips steeply to the south and east from the top of the hill, but within a short distance the dip flattens, so that this formation is at or near the surface most of the way to Batesville and beyond.

The Boone limestone is quarried extensively to the north and northeast of Batesville, where it appears as a massive, uniform, rather fine grained limestone of light-gray or brownish color. It is known in the trade as an oolite, but I have not seen evidence of oolitic structure in any of it.

A sequence similar to that which I have described as occurring along Spring Creek is also observed when White River Junction is approached from the west instead of from the north. My observations extend from a point about $2 \frac{1}{2}$ miles west of White River Junction. The first outcrop seen is the Batesville, which can be followed and recognized from the train as it appears at different levels in cuts and on the hillsides. At the locality mentioned it has a westerly dip of about $4^{\circ}$ and probably is on the western limb of a gentle fold. It is underlain by the usual grayish and greenish shales. 
Some distance to the east, the Boone is finely exposed in a long bluff. Here were seen 65 feet of fine-grained limestone and chert, for the most part light gray in color. The cherty limestone is heavily bedded and abruptly gives place laterally to purely calcareous strata. These beds where weathered seem to be thin bedded; where blasted, massive; and they are usually not noticeably cherty when freshly exposed. Toward the top the limestone becomes earthy and full of little holes resembling worm borings. Fragments of similar limestone were found up the hillside to the level of 50 feet above the highest exposure in place. The beds in this bluff, which affords outcrops for 562 paces, have a distinct though not high dip. to the east. In another cut 230 paces farther east is exposed 20 feet of nearly pure, finely crystalline light-gray to dark-gray limestone, overlain . by thin black sandy shale, black calcareous sandstone looking like black chert, black calcareous shale in thin sheets, and black limestone. This outcrop continues for 370 paces, the beds still having a gentle eastward dip. An interval of 170 paces separates this from the next cut, which gives 10 feet of fine, fissile greenish and black shale followed by 2 feet of calcareous black sandy shale and coarse calcareous sandstone, and this by 2 feet of thin, black shale. The dip is still toward the east. White River Junction is only 815 paces beyond, the interval showing no outcrops.

These cuts are so close together and so long and the beds descend at so low an angle that the exposures may be regarded as practically continuous. Though differing considerably in detail from the formation as exposed over the hill on Spring Creek, these beds of black shale and black earthy limestone resting on the Boone are clearly the same as the "Spring Creek limestone"; moreover, about half a mile to the east and a little north, at the point already described, is the hillside section completing the sequence up to the Batesville sandstone.

The fauna of the "Spring Creek limestone" has been listed by H. S. Williams, his collections forming part of those on which the present report is based. My own determinations do not in all cases agree with those of Professor Williams, but they probably differ no more than his final determinations would have differed from these preliminary ones if he had brought the fauna to a detailed study.

From 1248A1 (see Weller's section on p. 9) we have the following species:

Lingulidiscina newberryi var. ovata?

Productella hirsutiformis.

Productus subsulcatus?

Liorhynchus carboniferum.

liorhynchus carboniferum var. polypleurum.

Moorefieldella eurekensis.
Spirifer arkansanus.

Ambocœlia lævicula?

Nucula rectangula.

Bembexia nodimarginata?

Bactrites? smithianus?

Goniatites choctawensis? 
No. $1248 \mathrm{~A} 2$ has furnished us these:

Lingulidiscina newberryi var. caneyana.

Productella hirsutiformis.

Productus subsulcatus.

Liorhynchus carboniferum.

Liorhynchus carboniferum var. polypleurum.

Moorefieldella eurekensis.

Spirifer arkansanus.
Martinia sp.

Ambocœlia lævicula?

Composita aff. humilis.

Leda nasuta?

Bembexia nodimarginata?

Orthoceras aff. crebriliratum.

Goniatites choctawensis?

1248A3 and A4 seem to be without fossils.

In 1248A5 I have identified the following:

Lingula albapinensis.

Productella hirsutiformis.

Productus subsulcatus.

Productus subsulcatus var. janus.

Liorhynchus carboniferum.
Liorhynchus carboniferum var. polypleurum.

Moorefieldella eurekensis.

Ambocœlia lævicula?

No. 1248A6 furnishes:

Productella hirsutiformis.

Productus moorefieldanus var. pusillus? Moorefieldella eurekensis.

1248A7, 8, 9, 10 and 11 have as yet furnished no fauna, and 1248A12 but three species, as follows:

Lingulidiscina newberryi var. moorefield- | Productus moorefieldanus. ana?

Camarotœchia purduei var. agrestis.

The foregoing collections were made by Mr. Weller. Professor Williams made the following section at Spring Creek:

Section (1248R 1-5) at Spring Creek.

5. Lingula layer.

4. Black limestone.

3. Top of cherty layers.

2. Limestone.

1. Cushman chert.

I have identified the following species in bed 4 of Professor Williams's section:

Stenopora sp.

Lingula batesvillæ.

Productella hirsutiformis.

Productus pileiformis.

Productus moorefieldanus var. pusillus.

Productus biseriatus.

Diaphragmus elegans.

Liorhynchus carboniferum.

Camarotœchia purduei var. agrestis.

Moorefieldella eurekensis.

Harttina brevilobata.

Harttina brevilobata var. marginalis.
Spirifer arkansanus.

Spirifer moorefieldanus.

Spirifer increbescens.

Martinia glabra?

Spiriferina subelliptica var. fayettevillensis?

Composita subquadrata var. lateralis.

Eumetria marcyi.

Solenopsis nitida?

Deltopecten batesvillensis.

Bellerophon sp.

Strophostylus aff. carleyanus. 
Bed 5 furnished the following:

Productella hirsutiformis?

Productus moorefieldanus?

Liorhynchus carboniferum.

Liorhynchus carboniferum var. poly-
Moorefieldella eurekensis.

Moorefieldella eurekensis var. subcuboides?

Martinia sp.

Bembexia nodimarginata.

There is also a small lot numbered $1248 \mathrm{Rx}$. It has no corresponding entry in the Survey catalogue and it probably represents loose or float material. The four species which I have identified in the lot designated in this way are as follows:

Productus pileiformis.

Liorhynchus carboniferum?

Spirifer arkansanus.

Martinia glabra?

We have furthermore a lot numbered merely $1248 \mathrm{R}$. The specimens so labeled may possibly have been collected by Branner and Penrose in 1889 (Williams's collection was made the year following), or they may merely bear labels on which the distinguishing numerals have been accidentally omitted. The following species have been identified in 1248R:

Lingulidiscina newberryi var. caneyana.

Productus pileiformis.

Liorhynchus carboniferum.

Camarotœchia purduei var. agrestis.

Moorefieldella eurekensis.
Spirifer arkansanus.

Martinia glabra?

Composita subquadrata var. lateralis.

Parallelodon multiliratus.

Station 1248T of Professor Williams's catalogue consists of material found loose on the railroad embankment. It has furnished the following species:

Batostomella dubia.

Batostomella parvula.

Lingula batesvillæ.

Liorhynchus carboniferum.

Camarotœchia purduei var. agrestis.
Moorefieldella eurekensis.

Martinia glabra??

Solenomya? sp.

Edmondia crassa.

Cypricardinia moorefieldana.

$1248 \mathrm{~V}$ is a collection similarly made. I find a memorandum which says " $1248 \mathrm{~V}=\mathrm{Rx}$ of collection," and a list of species from $1248 \mathrm{~V}$ seems to comprise the faúnas of both of my lists. Among the specimens now labeled " $1248 \mathrm{~V}$," I have identified the three following species:

Productella hirsutiformis.

Martinia glabra?

Composita subquadrata var. lateralis?

Another group of float specimens is included in 1248Y. Among these I have identified the following:

Productus pileiformis.

Productus arkansanus var. multiliratus.

Liorhynchus carboniferum.

Liorhynchus carboniferum var. polypleurum.
Moorefieldella eurekensis.

:Moorefieldella eurekensisvar. subcuboides.

Productella hirsutiformis.

Productus inflatus var. coloradoensis? 
1248Z, also float, has supplied only Lingula batesvillæ.

Lot $1237 \mathrm{R}$ appears to be also from Spring Creek locality and contains the following:

Lingula batesvillæ.

Liorhynchus carboniferum.

Moorefieldella eurekensis.

Deltopecten batesvillensis.

Messrs. Adams and Ulrich collected at Spring Creek in 1902, but they did not discriminate the horizons in detail as did Mr. Weller. In their collection (2048) I have identified the following species:

Batostomella dubia.

Batostomella parvula.

Fenestella aff. rudis?

Fenestella aff. multispinosa?

Lingula batesvillæ.

Lingula albapinensis.

Lingulidiscina newberryi var. moorefieldana.

Lingulidiscina newberryi var. marshallensis?

Lingulidiscina newberryi var. caneyana.

Chonetes sp.

Productella hirsutiformis.

Productus inflatus var. coloradoensis?

Productus pileiformis.

Productus subsulcatus var. janus?

Productus moorefieldanus var. pusillus.

Productus biseriatus.

Rhipidomella arkansana.

Liorhynchus carboniferum.

Liorhynchus carboniferum var. polypleurum.
Camarotœchia purduei var. agrestis.

Moorefieldella eurekensis.

Spirifer arkansanus.

Reticularia setigera.

Martinia glabra?

Martinia sp.

Composita subquadrata var. lateralis?

Composita aff. humilis.

Sphenotus? sp.

Edmondia crassa.

Schizodus batesvillensis.

Deltopecten batesvillensis.

Allerisma walkeri var. abbreviatum.

Bembexia nodimarginata.

Bellerophon sp.

Strophostylus aff. carleyanus.

Paraparchites nicklesi.

Primitia moorefieldana.

Bairdia attenuata.

My own collecting at this point was done in 1907. But little of my material was obtained from rock in place; most of it was collected from large blocks evidently taken from the cutting near by and piled up to reinforce the bank at the trestle that has been mentioned as carrying the tracks over the sunken wagon road. The material from each block was kept separate and many of the horizons can be determined lithologically and faunally by comparing them with the collections of the series'1248. The thickness of rock through which these collections range, however, is so slight and the faunas themselves are so alike that, so far as I can see, no object is gained by keeping them separate. From a ledge of earthy limestone in place, along the railroad, crowded with Liorhynchus and Moorefieldella, I obtained the following (2049):

Productella hirsutiformis.

Productus subsulcatus. .

Productus moorefieldanus.

Productus moorefieldanus var. pusillus.

Liorhynchus carboniferum.
Liorhynchus carboniferum var. polypleurum.

Moorefieldella eurekensis.

Bembexia nodimarginata. 
One of the loose blocks mentioned above furnished these species (2049a):

Menophyllum sp.

Lingulidiscina newberryi var. moorefieldana?

Productella hirsutiformis var. batesvillensis.

Productus pileiformis.

Productus moorefieldanus var. pusillus.

Productus biseriatus.

Rhipidomella arkansana.

Liorhynchus carboniferum?

Spirifer arkansanus.

Spirifer moorefieldanus.

Reticularia setigera.

Martinia glabra?

Spiriferina subelliptica var. fayettevillensis?

Composita subquadrata var. lateralis.

Eumetria marcyi?

Parallelodon multiliratus.

Cypricardinia moorefieldana.

Deltopecten batesvillensis?

Deltopecten? sp.

Bucanopsis cancellata?

Orthoceras aff. crebriliratum.

Griffithides? sp.

Another loose block gave the following (2049b):

Batostomella parvula.

Fenestella aff. rudis?

Lingulidiscina newberryi var. moorefieldana.

Productus moorefieldanus?

Camarotœchia purduei.

Camarotœchia purduei var. agrestis.

Moorefieldella eurekensis.

Reticularia setigera.

Another (2049c) gives:

Lingula batesvillæ?

Lingulidiscina newberryi var. moorefieldana?

Lingulidiscina newberryi var. caneyana.

- Chonetes sp.

Productella hirsutiformis.

Productus inflatus var. coloradoensis?

Productus moorefieldanus var. pusillus.

From the ballast (2049d) near the southeast end of the outerop (evidently Professor Williams's Lingula layer) I obtained two species-Lingula batesvillæ and Deltopecten batesvillensis.

From another loose block from the trestle (2049f) the following forms were collected and identified:

Productella hirsutiformis?

Productus inflatus var. coloradoensis?

Productus pileiformis.

Liorhynchus carboniferum.

Spirifer arkansanus.

Composita subquadrata var. lateralis.

Fossils are rare in the black and greenish shales which compiise the upper and larger part of the Moorefield, and, indeed, most sediments of this character seem to be scantily fossiliferous. Nevertheless a few forms were obtained in a hillside exposure described on page 10 as about one-half mile northwest of White River Junction. From some concretions in the greenish sandy shale in the base of the outcrop (2052) I collected Caneyella percostata and Gastrioceras caney- 
anum; and from the black fissile shale about 20 feet above (2052a), Caneyella nasuta and Orthoceras sp. $b$.

I also made a collection (2053) in the black earthy limestone just above the Boone along the railroad west of White River Junction (see p. 12) in which the following species occurred:

Enchostoma bicarinatum.

Lingula albapinensis.

Lingulidiscina newberryi var. ovata.

Lingulidiscina newberryi var. caneyana.

Productella hirsutiformis.

\author{
Productus pileiformis. \\ Liorhynchus carboniferum. \\ Martinia glabra. \\ Parallelodon multiliratus. \\ Bembexia nodimarginata.
}

This is evidently the Spring Creek fauna, but the fossiliferous ledges are less numerous at this locality. Particularly noticeable for its absence is that in which Liorhynchus carboniferum and Moorefieldella eurekensis are so abundant. It will be observed that the latter species was not obtained at this locality.

With this the Survey collections at Spring Creek and vicinity come to an end. In the table on page 22 will be found the complete fauna of the "Spring Creek limestone" as contained in the collections and identified by me. In addition, however, I should mention that J. P. Smith has cited Goniatites newsomi from the "Fayetteville" (= Moorefield) shale at Batesville and also G. striatus and G. subcircularis, all three of which are included in the table on his authority. McChesney also described three species from a locality near Batesville-Nuculites [Leda] vaseyana, Nucula rectangula, and Pleurotomaria [Bembexia] nodimarginata - the horizon being given as "dark-colored shales of the age of the Hamilton rocks of New York." There can be no reasonable doubt that the horizon is really the Moorefield shale, and the locality is very probably that at Spring Creek.

Smith, who described an interesting goniatite fauna from Moorefield, states that his fossils (at least those of Bactrites carbonarius) were collected on the farm of O. P. Goodwin, near Moorefield, Ark. My own hurried visit to Moorefield was planned especially with a view to obtaining collections from the same horizons. I learned that a few of the early collections were indeed made from a well on the farm of O. P. Goodwin (now owned by Mr. McClure), but most of them were obtained on G. A. Godfrey's place, not far away, half a mile south and half a mile west of Moorefield. My informant was Mr. Godfrey himself, who told me that Doctor Branner stopped with him several days and who kindly accompanied me to several of the old localities. Just back of Mr. Godfrey's house black shales and black limestones are exposed in a little run. From the black limy shales I collected the Spring Creek fauna as follows (2051a):

Productella hirsutiformis.

Liorhynchus carboniferum.

46447ㅇ-Bull. $439-11-2$
Liorhynchus carboniferum var. polypleurum. Martinia sp. 
Just above (the whole included within the dimensions of a few feet) were rounded segregations of earthy limestone that were said to have furnished some of the goniatites of the earlier collections, and weathered sections, apparently through goniatites, corroborated this statement. These lenses were so large, rounded, and massive that they could not be broken with the ordinary geologic hammer, so that it was impossible to make a collection from this horizon. It seems evident at all events that some of the characteristic goniatites of the Moorefield shale occur in association with the Spring Creek fauna. Similar though poorer outcrops were seen in this run southward for about a quarter of a mile, where to the west there rises a hill on the top of which are abundant plates of thin-bedded, fine-grained sandstone (originally somewhat calcareous), containing many fossils of a few species, Deltopecten batesvillensis being very abundant. The fauna obtained here (2051b) comprised Liorhynchus carboniferum, Caneyella vaughani, and Deltopecten batesvillensis.

I am fairly satisfied that this is not the Batesville sandstone, for neither the fauna nor the lithology is that of the Batesville, the rock being far too thin, sheety, and fine grained for that formation. The top of the hill with its fossiliferous sandstone was at 440 feet (barometric). Four feet of black limestone and stiff black shale in the branch at the foot of the hill stood at 340 feet; the bed of the branch near Godfrey's house, where the collection was made, at 325 feet. The total thickness comprised in these observations is therefore 115 feet. I may mention that the 4 feet of black limestone and shalc at the foot of the hill was pointed out to me as being one of the localities at which the first collections were obtained, but I saw no evidence of this rock being fossiliferous.

Another locality at which some of the early collections were made was on top of the hill opposite Godfrey's house, east or somewhat southeast of it. In little runs and on the bare hillsides a nearly complete exposure of the Moorefield is obtained to the top, the rocks consisting of fissile, somewhat sheety black shale with very little limestone. The shales are scantily fossiliferous, though specimens of Liorhynchus were noted. At the top occur fragments of limestone holding (2051) Lingulidiscina newberryi var. caneyana, Strophostylus aff. carleyanus?, Orthoceras sp. b, Bactrites? carbonarius, and Goniatites choctawensis.

This limestone is collected by.local people and it was impossible to obtain more than a few small fragments with fossils. Using the outcrop back of Godfrey's again as a reference point, I found the top of this hill (station 2051) to be 100 feet above it, and consequently lower by 15 feet than the adjacent eminence on the top of which the sandstone with Deltopecten was so abundant. Of the latter no trace was seen. At this locality, then, there is about.115 feet in the middle 
of the Moorefield shale, which was estimated to be about 225 feet thick along Spring Creek, neither the Boone below nor the Batesville above being exposed in the immediate vicinity. If the fossiliferous limestone back of Mr. Godfrey's house, however, is to be considered as representing the horizon of the "Spring Creek limestone," the base of the formation can hardly be far below. Some distance west of Moorefield similar black shales crop out and underlie the typical Batesville, which can be traced onward to the town itself and the outcrops around it.

Other outcrops of the sandstone can be seen by one approaching Moorefield from the north. The sandstone is descending in that direction, the barometer reading 380 on one of two outcrops especially noted and 300 on the other. The latter was not far from the town of Moorefield. On the assumption that the barometer was correct, which may not be the case, as the atmospheric conditions were disturbed, the Batesville at that point is lower than any of the outcrops of Moorefield shale which I have described and the dip would carry the formation still lower. My observations were insufficient to determine whether this relation of the outcrops is due to faulting or to a reversal of the dips (the rocks on top of the hill opposite to Godfrey's appeared, however, to have a general dip southward) or to misleading barometric readings. If none of these is true, the Moorefield must overlie instead of underlie the Batesville sandstone. I do not believe, however, that this is the case. At all events the fauna at Moorefield is closely related to that of the "Spring Creek limestone." To the lists already given from the vicinity of Moorefield I must also add Pleurotomaria? sp., Orthoceras sp. a, Endolobus ornatus, and Goniatites choctawensis, which were collected by Mr. Siebenthal (2051C) in the early work that was done in this region; and a few ammonoid species, (Bactrites carbonarius, Glyphioceras calyx, ${ }^{a}$ and Goniatites crenistria), cited by Professor Smith in his monograph, some of which have been noted in our own collections.

The third and last locality from which Moorefield fossils have been obtained in the Batesville region is Howards Wells, near Sharps Crossroads, northeast of Batesville and of Moorefield. Howards Wells are natural mineral springs which have been excavated to some extent, furnishing for the local market a mineral water which is either condensed and bottled or reduced to a crystalline salt by evaporation. The locality is about $1 \frac{1}{4}$ miles east and half a mile north from Sharps Crossroads. There are no outcrops worth mentioning in this vicinity. The fossils were thrown out in excavating the wells a good many years ago and were donated by Mr. Howard himself. My barometer gave a reading of 395 feet at the wells, and the fossils were obtained from 10 to 20 feet below the surface. About half a mile west of Sharps 
Crossroads the Batesville, which can be traced with reasonable success from Batesville itself, crops out at 415 feet, and if we may assume that Howards Wells is about on the strike, as seems to be the case, the horizon from which the fossils were obtained would appear to be 30 feet below the top of the Moorefield. At all events it seems wellnigh certain that the horizon is below the Batesville and probably in the upper rather than in the lower half of the Moorefield shale. The earlier fossils (1245A) obtained at this point were Goniatites choctawensis, Gastrioceras caneyanum, Eumorphoceras bisulcatum, and Adelphoceras mesterianum. Mr. Howard álso gave me a single specimen which I have figured as Gastrioceras caneyanum (1245B). The collection 1248X, which seems to have been made from this vicinity, contains a single species, Deltopecten batesvillensis.

In this case, as in the others, the species. which are known from the Moorefield shale at Howards Wells and vicinity are shown in a separate column of the table on page 22 .

The only locality near Marshall at which I found the shales between the Batesville and the Boone satisfactorily shown is in a little ravine on the northeast edge of the town. The Moorefield here has a thickness of less than 40 feet. The constituent beds are as follows:

Section in ravine near Marshall, Ark.

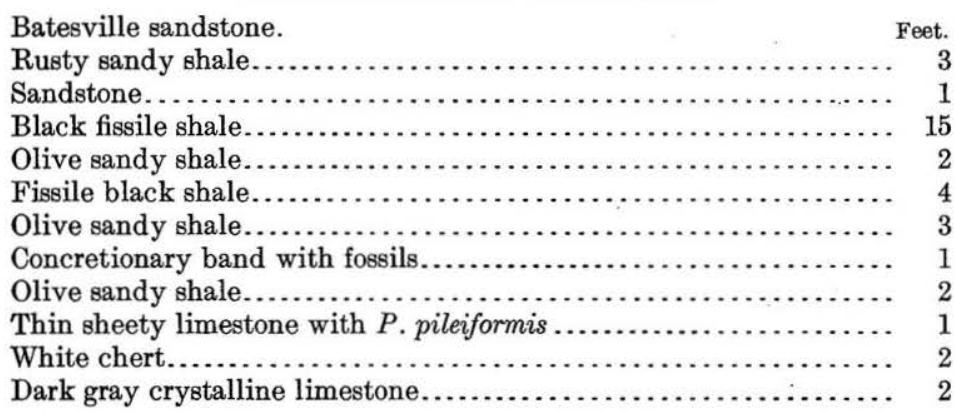

For the present I am regarding the thin limestone with Productus as the base of the Moorefield, the underiying beds being referred to the Boone, while the upper limit of the formation may best be taken at the top of the black shale, the first layer of sandstone initiating the Batesville.

In the way of fossils these outcrops have not proved very fruitful, although a few species, Lingula, Liorhynchus, and Camarotæchia, are abundant. The lower bed, resting directly upon the Boone, and perhaps belonging to it, has yielded only Productus pileiformis (7038a). Two feet above occur some large, slightly calcareous concretions, from which the following species were collected (7038):

Lingulidiscina newberryi var. marshallensis.

Lingulidiscina newberryi var. moorefieldana?

Liorhynchus carboniferum.

Liorhynchus carboniferum var. polypleurum. 
From a thin, calcareous, sandy band about 8 feet above the Boone, I obtained, in 1908, the following species (7038c):

Lingulidiscina newberryi var. marshallensis.

Liorhynchus carboniferum.

Liorhynchus carboniferum var. polypleurum.

Leda vaseyana?

Schizodus batesvillensis?

From the concretions in a thin, earthy limestone in the black shale, about 20 feet above the Boone, I collected (7039)-

Lingulidiscina newberryi var. marshallensis.

Chonetes sericeus.

Camarotœchia purduei var. laxa.
Solenopsis nitida?

Nucula rectangula.

Caneyella wapanuckensis?

Pleurotomaria? sp.

If the formations are the same at Batesville and at Marshall, as seems probable, certain important changes must be noted. The most striking is probably the diminution in the thickness of the Moorefield shale, which measures about 225 feet on Spring Creek and less than 40 feet at Marshall. The general character of the formation remains the same, however, although naturally the detail of the calcareous beds in its lower part varies from place to place. The faunas at Marshall (see table on p. 22) also present many differences from those of the "Spring Creek limestone," partly in being less varied and partly in containing different as well as fewer species. The most noteworthy of the absentees is probably Moorefieldella eurekensis, which, though abundant on Spring Creek, is known at no other place in the Moorefield shale. Productella hirsutiformis is also absent, as are also the other productoid types, and also Spirifer arkansanus, etc. Liorhynchus, another characteristic species, occurs in a smaller, generally narrower, mutation, which, though in some measure discriminable, I have cited as the same species. I may note at this point that a larger, more characteristic form occurs at a much higher horizon at Marshall near the top of the black shale above the Batesville sandstone.

The accompanying table shows the fauna of the Moorefield shale and its distribution at the four localities from which fossils are known-from near Batesville on Spring Creek and near by on White River; from near Moorefield; from Howards Wells near Sharps Crossroads, in the Batesville quadrangle; and from near Marshall in the Marshall quadrangle. It will be observed that nearly all the species known come from the Spring Creek locality, the others having furnished but a scattering representation. The cephalopods, one of the most interesting features of the fauna, are proportionally far better represented at Moorefield and Howards Wells. They are practically absent from the survey collections obtained at Spring Creek, but Professor Smith cites several species, probably from that locality. They appear to be especially abundant in the upper part of the forma- 
tion, while the brachiopods are largely segregated in the "Spring Creek limestone," in the lower part. The fauna from Marshall lacks many of the characteristic Moorefield types and shows some positive as well as negative peculiarities:

Table showing distribution of species of the Moorefield shale in the Batesville and Marshall quadrangles.

\begin{tabular}{|c|c|c|c|c|c|c|c|c|c|}
\hline & 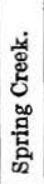 & 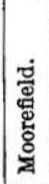 & 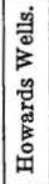 & 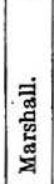 & . & 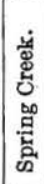 & 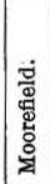 & 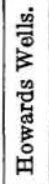 & 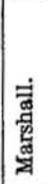 \\
\hline ten & $x$ & & & & Martinia sp..... & $x$ & $x$ & & \\
\hline & $\hat{x}$ & & & & Ambocolia lævicula & $\hat{x}$ & & & \\
\hline Batos & $\hat{x}$ & & & & Spiriferina subelliptica & & & & \\
\hline ella parvula ... & $\underset{x}{x}$ & & & & ette villensis........................... & 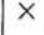 & & & \\
\hline $\begin{array}{l}\text { Stenopora sp............ } \\
\text { Fenestella aff, rudis? }\end{array}$ & $\underset{x}{x}$ & & . & & $\begin{array}{l}\text { Composita subquadrata var. } \\
\text { lateralis }\end{array}$ & & & & \\
\hline $\begin{array}{l}\text { Fenestella aff. rudis?......... } \\
\text { Fenestella aff. multispinosa? }\end{array}$ & $\stackrel{x}{x}$ & & $\cdots$ & & Composita madisonensis var. & $\mathrm{X}$ & & & |.. \\
\hline Ling & $\hat{x}$ & $\cdots$ & $\cdots$ & & 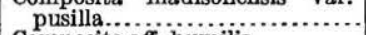 & $x$ & & & $\cdots$ \\
\hline albapine & $\hat{x}$ & ... & & & Composita aff. humil & $x$ & & & $\cdots$ \\
\hline Lingulidiscina ne & & & & & Eumetria marcyi. & $x$ & & & \\
\hline moorefieldans.. & $x$ & & & $?$ & Solenomya? sp..... & $x$ & & & $\pi$ \\
\hline Lingulidiscina newberryi & & & & & Sphenotus? mesleriar & $x$ & & & \\
\hline $\begin{array}{l}\text { marshallensis....... } \\
\text { Lingulidiscina newb }\end{array}$ & $?$ & & & $x$ & $\begin{array}{l}\text { Sphenotus? sp...... } \\
\text { Solenopsis nitida?. }\end{array}$ & $\stackrel{x}{x}$ & & & $x$ \\
\hline $\begin{array}{l}\text { Linguilascina ne } \\
\text { ovata............. }\end{array}$ & $x$ & & & & Edmondia crassa.. & $\hat{x}$ & $\cdots$ & & \\
\hline Lingulidiscina newberryi var. & & & & & Nucula rectangula. & $\hat{x}$ & & & $x$ \\
\hline 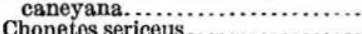 & $x$ & $x$ & & $x$ & Leda & & ? & & $\cdots$ \\
\hline sp......... & $x$ & & ... & $x$ & lodon multilir & $\stackrel{x}{x}$ & $\begin{array}{l}\cdots \\
\cdots\end{array}$ & & $\cdots$ \\
\hline hirsutiforr & $x$ & $x$ & & & Cypricardinia? & $\hat{x}$ & & & $\cdots$ \\
\hline Productella hirsu & & & & & Caneyella vaug & & $\ddot{x}$ & & \\
\hline 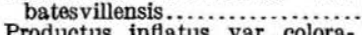 & $x$ & & & & Caneyella wapanucke & & & & $\mathrm{x}$ \\
\hline $\begin{array}{r}\text { Productus inflatus var. colora- } \\
\text { doensis? }\end{array}$ & $x$ & & & & $\begin{array}{l}\text { lla percostats. } \\
\text { lla nasuta..... }\end{array}$ & $\stackrel{x}{x}$ & {$\left[\begin{array}{ll}\cdots \\
\text { a }\end{array}\right.$} & .. & $\ddot{*}$ \\
\hline Productus arkansanus var. mul- & & & & & Schizodus batesville & & & & $?$ \\
\hline & $x$ & & & & batesvill & $x$ & $x$ & $x$ & $\cdots$ \\
\hline Prod & $x$ & & & $x$ & eten? $\mathrm{s}$ & $x$ & ... & & $\cdots$ \\
\hline Prod & $x$ & & & & Allerisma walkeri va & & & & \\
\hline Proc & $x$ & & & & & $\underset{x}{x}$ & & & $\cdots$ \\
\hline janus. & $x$ & .. & ... & & Bembexia r & $x$ & & & \\
\hline Prodi & $x$ & ... & ... & $\ldots$ & Pleurotoma & & $x$ & $\cdots$ & $x$ \\
\hline tus moorefieldanus var. & & & & & cancéllat & $\stackrel{x}{x}$ & ( & .. & $\cdots$ \\
\hline s eles & $\hat{x}$ & & & & ylus afti. car & $\hat{x}$ & $\ddot{?}$ & $\ldots$ & $\cdots$ \\
\hline & $\hat{x}$ & & .. & & Orthoceras aff. crebriliratum..... & $x$ & & & \\
\hline Lior & $\hat{x}$ & $x$ & ... & $\mathrm{x}$ & Orthoceras sp. a. & & $x$ & &.. \\
\hline um var & & & & & Orth & $\times$ & $x$ & & .. \\
\hline & $x$ & $x$ & & $x$ & End & & $\mathrm{x}$ & & $\ldots$ \\
\hline Camarot & Y & & & & ites? car & & $x$ & & \\
\hline Camarotœechia purduei var. & & & & & ites? smit & $\ddot{x}$ & & & .. \\
\hline & $x$ & $\cdots$ & & & ites cho & ? & $\underset{x}{x}$ & $x$ & $\cdots \cdot$ \\
\hline Cama & & $\ldots$. & & $\mathrm{x}$ & Goni & У & $x$ & & $\cdots$ \\
\hline $\begin{array}{l}\text { Moorefieldella eurekensis............ } \\
\text { Moorefieldella eurekensis var. }\end{array}$ & & & & & $\begin{array}{l}\text { Goniatites subcircula } \\
\text { Goniatites newsomi }\end{array}$ & $\stackrel{x}{?}$ & & & \\
\hline $\mathrm{s}$ & $x$ & & & & Gastrioceras richardsonianum?.. & & $\ddot{?}$ & & ... \\
\hline brevilobat & $x$ & .. & .. & .... & Gastrioceras caneyanum. & $x$ & $\cdots$ & $\underset{x}{x}$ & $\cdots$ \\
\hline reviloba & & & & & & & & 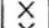 & \\
\hline & & & & & Ade & & $\ldots$ & $\mathrm{x}$ & \\
\hline & $\underset{x}{x}$ & … & $\cdots$ & … & Griffithides? sp & $\stackrel{x}{x}$ & $\cdots$ & $\cdots$ & $\cdots$ \\
\hline & $\underset{x}{x}$ & $\cdots \cdot$ & $\cdots$ & … & 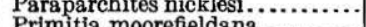 & $x$ & & $\cdots$ &.. \\
\hline & $\underset{x}{x}$ & $\cdots$ & $\cdots$ & $\cdots$ & & & $\cdots$ & & \\
\hline $\begin{array}{l}\text { Reticularia } \\
\text { Martinia gla }\end{array}$ & $\stackrel{x}{x}$ & & & & Bairdia attenu & $x$ & & & \\
\hline & & & & & & & & & \\
\hline
\end{tabular}

Some of the most striking features of the Moorefield shale have already been pointed out by $\mathrm{H}$. S. Williams, ${ }^{a}$ who noted its relationship to the early faunas of the Carboniferous section of Nevada,

a Am. Jour. Sci., 3d ser., vol. 49, 1895, pp. 94-101; Ann. Rept. Geol. Survey Arkansas for 1892, vol. 5, 1900, pp. 341-354. 
especially vested in such species as Liorhynchus carboniferum, Productella hirsutiformis, and Moorefieldella eurekensis. The Moorefield fauna has generally been regarded by paleontologists as correlating with the Méramec ("St. Louis") group. The stratigraphic position of the Moorefield immediately above the Boone is very suggestive of such an alignment, and it seems probable that it is correct, but at the same time, there are very few species which can be definitely identified in both faunas. ${ }^{a}$ On the other hand, some of the Moorefield forms are definitely suggestive of a higher horizon than the Meramec. Those which might be taken as indicating a Kaskaskia rather than a Meramec age are Diaphragmus elegans, which has not, I believe, been recognized below the Kaskaskia; Harttina brevilobata, which was described from the Kaskaskia, but is very closely related to Dielasma turgidum of the Meramec (which I suspect to be a Harttina); Reticularia setigera, which may very well range down to the lower horizon and grade into $R$. pseudolineata, from which it is doubtless descended; and Martinia glabra, which, though not identical with $M$. contracta of the Kaskaskia, still presents a genus at present unknown in the Meramec ("St. Louis"). I desire to defer. a definite expression of opinion regarding the correlation of the Arkansas beds with the standard section of Illinois, Missouri, and Iowa, until all the Mississippian faunas of Arkansas have been studied; but it is doubtless safe to affirm that the Moorefield fauna and all the higher faunas of the Mississippian in Arkansas present numerous and important differences from the corresponding faunas of the standard section. Indeed, I am coming to believe that the standard section of Missouri, Illinois, Iowa, etc., represents conditions which, speaking in a broad way, were specialized and local. Over extensive areas in Mississippi, Alabama, and Oklahoma, probably also in Kentucky, Tennessee, and southern Indiana, the upper Mississippian is to a greater or less extent a black shale formation. Nevada may also probably be cited as belonging to this list, while the general absence of the upper Mississippian beds over the West may, perhaps, be a fact pointing in the same direction, for such a formation would be easily eroded down to the limestone of the lower Mississippian, which usually forms the floor upon which the Pennsylvanian rests. These black shales, it is true, are associated with beds of limestone, the faunas of which are much more likely to agree with those of the typical section (which consists mainly of limestone with little or no black shale) than do the faunas of the black shales and of the black limestones embedded in the shales, which contain a peculiar fauna that is perhaps more generalized and more widely spread than those of the standard section. The same is true, though to a some-

a Productus biseriatus, Bellerophon textilis, and Paraparchites nicklesi probably constitute the strongest evidence for calling this fauna Meramec ("St. Louis"). 
what less degree, of the Lower Carboniferous, for it is possible that the lower Mississippian limestones of the standard section (which extend, however, widely to the west and southwest and northwest) are represented by black shales in Tennessee, and possibly other areas, as in Alabama and Oklahoma, just as they are represented by black shales and shales of other colors, together with sandy beds in Ohio and Pennsylvania. There is certainly something significant and important in the persistence of black-shale conditions through so much of Devonian and Mississippian time, ${ }^{a}$ together with the accumulation of limestones in certain areas and of more sandy beds in others, although the exact significance is as yet imperfectly understood. At all events, the peculiar fauna of the Moorefield shale is probably to be connected with some broad system of faunal distribution as yet only vaguely conceived and depending on conditions of temperature, currents, sedimentation, and environment generally, whose workings are still more obscure.

There is one relationship of the Moorefield fauna which was not touched on by Professor Williams, because the complementary fauna was not known at the time of his writing. I mean that with the fauna of the Caney shale of Oklahoma. As at present known, this fauna ${ }^{b}$ consists of 50 species and varieties of invertebrates, besides an unusually large number of indeterminata. The general character of the fauna is shown in the following list, in which the asterisk is employed to indicate species which occur also in the Moorefield shale. The certainty of the identification differs considerably in different species. Other Caney species are found in the Batesville sandstone and Fayetteville shale.

Lingula paracletus Hall and Clarke.

*Lingula albapinensis Walcott.

*Lingulidiscina newberryi var. caneyana n. var.

*Lingulidiscina newberryi var. ovata $\mathrm{n}$. var.

Lingulidiscina batesvillensis Weller.

Chonetes planumbonus var. choctawensis n. var.

*Productella hirsutiformis Walcott.

*Productus pileiformis McChesney.

*Liorhynchus aff. mesicostale Hall=L. carboniferum.

${ }^{*}$ Liorhynchus aff. laura Billings $=\mathrm{L}$. carboniferum var. polypleurum.

*Spirifer $\mathrm{sp} .=$ Spirifer arkansanus.

*Martinia sp.
*Composita? sp. see Liorhynchus carboniferum.

Deltopecten? caneyanus n. sp.

*Caneyella wapanuckensis n. sp.

*Caneyella vaughani $\mathrm{n}$. sp.

*Caneyella nasuta $\mathrm{n}$. sp.

*Caneyella percostata n. sp.

Caneyella richardsoni n. sp.

*Parallelodon multiliratus n. sp.

Conocardium sp.

Lævidentalium venustum Meek and Worthen.

Pleurotomaria? sp.

Naticopsis sp.

Macrocheilus? micula n. sp.

Macrocheilus? sp.

Orthoceras wapanuckense n. sp.

$a$ It is hardly necessary for me to say that speculations more or less similar to these have been made by others and no claim to originality is implied in them. The whole subject is, in fact, common property.

b Girty, G. H., Fauna of the Caney shale of Oklahoma: Bull. U. S. Geol. Survey No. 377, 1909. 
Orthoceras caneyanum n. sp.

*Orthoceras crebriliratum n. sp.

Orthoceras choctawense n. sp.

Orthoceras indianum n: sp.

Orthoceras sp.

Cycloceras ballianum n. sp.

Actinoceras vaughanianum n. sp.

Cyrtorizoceras? hyattianum n. sp.

Cœlonautilus gratiosus n. sp.

Bactrites? quadrilineatus n. sp.

*Bactrites? smithianus n. sp.

${ }^{*}$ Gastrioceras richardsonianum n. sp.
${ }^{*}$ Gastrioceras caneyanum n. sp.

*Goniatites choctawensis Shumard.

*Goniatites newsomi Smith.

Goniatites sp. a.

Goniatites sp. b.

*Adelphoceras meslerianum n. sp.

*Eumorphoceras bisulcatum n. sp.

Trizonoceras typicale sp.

Trizonoceras lepidum n. sp.

Cytherella aff. benniei Jones, Kirkby, and Brady.

Entomis unicornis n. sp.

A large number of forms are common to the two formations, and the foregoing list does not, of course, include species which are common to the Caney and to the Batesville and Fayetteville, for at present I am disposed to correlate all three of the Arkansas formations with the Caney. When the distance which separates them is considered, the resemblance between the two faunas is unusually strong. On the whole, it appears to me that the resemblance of the Caney fauna and that of the Moorefield shale in the Batesville quadrangle is more notable than that between the Moorefield fauna in the Batesville quadrangle and the same fauna relatively a short distance away at Marshall and is much stronger than with the typical Mississippian fauna, with which the Moorefield is correlated. It seems desirable to lay stress on this point because some imperfect plant remains found in the Standley shale 7,000 or 8,000 feet below the Caney seem to indicate a Mississippian if not a Pennsylvanian age. Even if the plants could be interpreted as belonging in the early Mississippian it would be at least unexpected to find the Mississippian so thick (10,000 feet and more) and composed entirely of such sediments (sandstones and shales). If the plants indicate upper Mississippian, the difficulties are proportionally increased, while if they indicate Pottsville there is, of course, a direct contradiction between the evidence of the plants and shells. Mr. White's statement regarding the plant remains obtained in the Standley shale is as follows:

All the material, except one specimen of Asterocalamites scrobiculatus and the single minute fern pinnule, is more or less macerated and obscure, the collection consisting chiefly of drift-rounded or comminuted and more or less macerated bits of stems roots, and bark, of no value except as showing that they fall within the epoch of vascular or woody plants (post-Silurian). The material is not of a nature or state of preservation to justify anything like a close correlation. The plant beds are Carboniferous. It is probable that they belong either in the upper part of the Mississippian or in the lower Pottsville, but this point requires additional paleontologic data for its determination.

In discussing this perplexing circumstance in my report on the Caney fauna, I mentioned a number of possibilities which would have 
to be considered if the more extreme interpretation of the plant evidence suggested by Mr. White was correct and the geologic age of the Caney were really Pottsville, so that we would have to look upon the Moorefield-Caney fauna as persisting from the Mississippian into the Pennsylvanian. Since describing the Caney fauna, I have been able to study that of the Moorefield and other related faunas and to give the subject more careful consideration from a different and broader point of view. At present, it seems to me that those expressions were almost unnecessary and that it is hardly possible, or at all events hardly probable, that such a survival took place. A priori, one would say that a species or two might pass over from the Mississippian into the Pennsylvanian, but hardly so many species, amounting practically to a large and characteristic part of the fauna. I doubt whether such a survival is known in all paleontology, or at least anywhere else in North America. In the region of Arkansas and Alabama, in which conditions seem to have been similar to those in Oklahoma, the upper Mississippian fauna, in some of its aspects closely related to that of the Caney and Moorefield, persists with its characteristic expression only to a certain zone, where it is succeeded by a fauna of different faciesthat of the Pottsville. This fact does not necessarily substantiate the position which I am inclined to take with regard to the age of the Caney, except in so far as there seems to be a general agreement as to the beds involved, whether the determination of their age rests upon the evidence of fossil plants or of fossil shells. At all events, I should judge that the invertebrate evidence as to the age of the Caney is vastly stronger than that furnished by the Standley plants (which, as Mr. White clearly indicates, are very poor and of doubtful import), not only in the number of species found elsewhere in rocks of recognized geologic age, but also in the certainty with which their preservation permits them to be identified.

Yet, should it prove that the Standley plants do in reality belong to a Pottsville flora, there is, by report, another case curiously parallel to this-that of the Riversdale beds in Nova Scotia. In that region also we have apparently a Pottsville flora said to underlie stratigraphically a Mississippian fauna. There are, to be sure, some differences in the situation as exhibited in Nova Scotia and Oklahoma. The flora of the Riversdale is, if I am not mistaken, much more extensive and more perfectly preserved than that at present known from the Standley,.and its Pottsville affinities, according to Mr. White, are much more strong and certain. The stratigraphic relations of the Caney as overlying the Standley and Jackfork are, I should infer, clearer and more completely established than the relation of the Horton series as overlying the Riversdale beds. As to the age of the faunas supposed in each case to be Mississippian, it seems to me that the relationship of the Caney fauna with recognized Mississippian 
faunas is fully as strong, if not stronger than that of the Horton series. However, although there is a possible contradiction of evidence in both these cases, I have faith that, when all the facts are known, the testimony of the plants and invertebrates will not be found at variance, and that these two apparent anomalies will, though perhaps by different courses, come into agreement with what seems to be the general order elsewhere.

It is possible that the invertebrate evidence from the Caney shale may be misleading, although at present that seems scarcely probable. There is also a possibility, which I should scarcely venture to suggest if the fossil plants were more diversified and better preserved, that the plant evidence may be misleading. No one, I am sure, holds in higher esteem than do I the genius and erudition which distinguish Mr. White's interpretation of fossil plants, but all work in stratigraphic paleontology proceeds from inferences which depend on the least trustworthy of deductive processes, deduction by simple enumeration, and which have to be revised from time to time as new evidence is brought to light. Indeed, the present paper, as already noted, seems to show some Kaskaskian species in a fauna generally regarded as of Meramec ("St. Louis") age. It is perhaps possible that there has happened to the plant evidence on a small scale something parallel to what I hesitate to admit has happened to the invertebrate evidence on a larger scale, and that the known range of a few plant species will have to be extended downward because of this occurrence in Oklahoma in the Standley shale. 


\title{
DESCRIPTION OF SPECIES.
}

\author{
CELENTERATA. \\ ZAPHRENTID $A$. \\ Genus MENOPHYLLUM Milne-Edwards and Haime.
}

MENOPHYLLUM sp.

Of this species the collections contain only one specimen, and it is imperfect. The most striking feature is the profound cup, which has a depth of $27 \mathrm{~mm}$., while the whole coral was probably not over $45 \mathrm{~mm}$. long. The rate of expansion appears to be rather rapid. It is estimated that there were about 36 septa in the cup and they may have been primary and secondary. Tabulæ and interseptal tissue appear to be wanting, but the bottom of the corallum is filled with stereoplasmic deposit. The exterior is marked by the usual longitudinal striations, which are rather strong.

So far as shown, this fossil has all the characters of Menophyllum, but the presence of the fossulæ has not been determined.

Horizon and locality.-Moorefield shale, Batesville quadrangle, Spring Creek (station 2049a).

\section{HELMINTHA.}

Genus ENCHOSTOMA Miller and Gurley.

Enchostoma bicarinatum n. sp.

Plate X, figure 1.

The fossils under this title consist of thin flattened filaments crossing the surface of a block of black shaly limestone. They suggest grasslike leaves of sea plants, but have the shiny phosphatic luster of Lingula and Conularia. The longest specimens measure over $30 \mathrm{~mm}$., have subparallel sides, and are apparently incomplete at both ends. The largest have a diameter of only $1.25 \mathrm{~mm}$. They differ in appearance according to their position in the rock, two opposite sides being, as it were, stiffened and reinforced into carinæ and the intermediate membrane being more tenuous and flexible. In one position the two sides are sharply defined by slightly raised ridges, the intervening con- 
nective tissue being flattened and less substantial. When turned on the side they show a central carina with another corresponding to it concealed in the rock. In this position the width, as represented by our specimens, is narrower than in the other. Whether this is due to an original difference in the width of the specimens or is connected with the structure and the position in which they lie in the rocks I am unable to state, although it is my belief that the latter is the case.

There can, I think, be little doubt that this organism is of the same general character as that to which Miller and Gurley gave the name Enchostoma, although it is pretty certain that it is a distinct species from $E$. lanceolatum. It is even debatable whether this form with its well-defined, thickened sides might not be advantageously distinguished as a different genus from the unoriented E. lanceolatum.

Horizon and locality.-Moorefield shale, Batesville quadrangle, Spring Creek (station 2053).

\section{BRYOZOA.}

\section{BATOSTOMELIID E.}

\section{Genus BATOSTOMELLA Ulrich.}

Batostomella dubia n. $\mathrm{sp.}$

Plate X, figyres 2, 3 .

Like Batostomella parvula, with which it is associated, this form occurs as fragments exposed in the rather sandy "Spring Creek limestone." The following description is therefore based on the study of thin sections alone.

The mode of growth is ramose, the cylindrical branches appearing to divide rather frequently; they have a diameter of about 1.5 to $2 \mathrm{~mm}$. The zoœcia appear to remain parallel through the axial portion, which is about two-thirds of the thickness of the stem, for a long distance, and to bend outward rather strongly. In a distance of $2 \mathrm{~mm}$. eight to ten cells occur. The apertures are elliptical or oval with rather thin walls. Mesopores are present in moderate abundance but their size and arrangement is variable. So is that of the acanthopores, many of which are large; but they are of different sizes, and instead of regularly surrounding the zoœcia they occur singly or in groups, generally in the angles between adjacent cells. Septa are scantily developed.

In the thickness of the branches $B$. dubia resembles $B$. spinulosa rather more than $B$. abrupta or $B$. nitidula, but in the thinness of the walls, in which this species is peculiar, it resembles $B$. nitidula. In addition to having thinner walls it differs in having larger, less numerous, and more irregularly distributed acanthopores. 
B. dubia seems to be the least characteristic of the Carboniferous species of Batostomella and in some respects stands midway between that genus and Stenopora, although its affinities appear to be greater with the former. The thinness of the walls and the scanty development of the acanthopores are suggestive of Stenopora rather than of Batostomella. The more extensive development of mesopores, the narrow cortical zone, and the absence of moniliform thickenings are characters rather of Batostomella than of Stenopora, although in the associated $B$. parvula the beaded character of the thickening is scarcely more apparent than in the present form.

Horizon and locality.-Moorefield shale, Batesville quadrangle, Spring Creek (stations 1248T, 2048.)

\section{Batostomella parvula Girty.}

Plate IX, figure 1.

1910. Batostomella parvula. Girty, New York Acad. Sci., Annals, vol. 20, No. 3, pt. 2, p. 191.

Basal Fayetteville shale: Fayetteville quadrangle, Arkansas.

The zoarium consists of branching cylindrical stems which rarely exceed $3 \mathrm{~mm}$. in diameter, although one thin section measures $7 \mathrm{~mm}$. The growth seems to have been irregular and the branching frequent, the $7 \mathrm{~mm}$. section probably representing one of the points of division where the diameter would naturally be greater than normal. Apertures small, six or seven in $2 \mathrm{~mm}$., subpolygonal. Walls moderately thickened in the mature region, which has a considerable thickness, in some cases one-third of the branch on either side. The thickening is uniform rather than beaded, the enlargements being fused. Mesopores absent, acanthopores of medium size or small, rather scantily developed, restricted to the angles. Septa few, found chiefly in the immature region. Walls seldom showing lines of junction.

This species, which is fairly common in the "Spring Creek limestone," is known only from fragments embedded in rock and from thin sections. It might be regarded as a Rhombopora, rather than be assigned to any of the other genera representing the Batostomellidæ, were it not that the hemi-septa appear to be absent, the thickened region is much too extended, and the walls themselves too thin and have too slight a development of acanthopores and spines to permit the admission of the species into that group. Of the stenoporas this species resembles $S$. americana, S. americana var. varsoviensis, $S$. intercalaris, $S$. angularis, S. ramosa, and $S$. meekana in having a ramose mode of growth, but of these the one most closely approaching it in the slenderness of the branches is $S$. ramosa. B. parvula has many other characters in common with $S$. ramosa, the chief difference being the much greater development of septa in the latter species, 
especially in the mature region. The walls also appear to be somewhat thicker, showing the division line between adjacent cells, and the mesopores are more numerous. The Moorefield form, therefore, can probably with safety be distinguished from S. ramosa and identified with $B$. parvula, with which it agrees very closely.

Horizon and locality.-Moorefield shale, Batesville quadrangle, Spring Creek (stations 1248T, 2048, 2049b).

\section{STENOPORA sp.}

This species is chiefly known through a section cutting longitudinally through the cells of a small fragment. In a general way it resembles $B$. parvula, but the growth seems to be lamellar rather than ramose. There are six or seven cells in $2 \mathrm{~mm}$. The walls are considerably thickened toward the outer surface, but the thickening does not assume an intermittent or beaded shape. The walls below are sinuous. The septa are fairly abundant, in which respect also the difference from $B$. parvula is shown, but very irregular in their distribution, and they appear to be entire. In the absence of a transverse section the distribution of the acanthopores and other characters can not be described.

Horizon and locality.-Moorefield shale, Batesville quadrangle, Spring Creek (station 1248R4).

\section{FENESTELLID $A$ E.}

Genus FENESTELLA Lonsdale.

Fenestella aff. RUDIS Ulrich ? ${ }^{a}$

The bryozoa are poorly represented in the fauna of the Moorefield shale, and of the fenestellas, a genus which is at some localities extremely abundant at or near this horizon, we have only six small fragments, representing apparently two species. Three specimens belong to a type which in some respects seems to be closely allied to Fenestella rudis and F. limitaris of the Keokuk. They show the back of the frond, which is marked by somewhat intermittent striæ, rather strong and coarse on some areas and in some conditions of preservation, but in other places is apparently smooth.

Horizon and locality.-Moorefield shale, Batesville quadrangle, Spring Creek (stations 2048, 2049b).

\section{Fenestella aff. multispinosa Ulrich $?^{b}$}

Of this type our collection contains only three rather small fragments showing the back of the frond. It is chiefly distinguished by its regular growth, its squarish or subcircular fenestrules, and the 
nearly equal size of the branches and dissepiments. There are eleven or twelve branches in $5 \mathrm{~mm}$. and ten fenestrules in the same distance. These measurements do not quite agree with $F$. multispinosa, and, furthermore, the surface appears to be smooth and quite without the spines of that species. One specimen provisionally referred here shows when exfoliated rather fine, strong, longitudinal striation. This is a distinctly coarser form than $F$. tenax, and if all its characters could be determined it would probably prove to be new.

Horizon and locality.-Moorefield shale, Batesville quadrangle, Spring Creek (station 2048).

\section{BRACHIOPODA.}

\section{LINGULID $A$.}

\section{Genus IINGULA Bruguière.}

Lingula Batesville n. $\mathrm{sp.}$

Plate I, figures 1-10.

Shell rather large, oblong-ovate. Length is to the width as the proportion of 3 to 2, varying to the proportion of 5 to 3 . Ventral valve distinctly longer and more acutely pointed behind than the dorsal. Sides nearly straight or slightly curved, somewhat contracting posteriorly, more nearly parallel in some specimens than in others. Anterior end strongly rounded, occasionally more or less flattened. Posterior extremity bluntly rounded in the dorsal valve, produced in the ventral into an angular outline with curving sides. Convexity high.

Most of the specimens representing this species are more or less exfoliated. On such small areas as probably retain the original markings the surface is seen to be faintly and irregularly roughened and marked by only obscure incremental lines.

Shell substance thick, owing to which circumstance the muscular imprints are more than usually clearly marked. They differ rather conspicuously in the two valves. In the ventral valve the visceral area is somewhat shield shaped, but inverted, so that the broad end is anterior and the pointed end posterior, and elongated so that it occupies distinctly more than half the length of the shell. The most definite scars observed in this valve are two large ovate ones strongly oblique and symmetrical to the median line, their lower margins being coincident with the margin of the visceral area. They do not meet along the median line, being separated by a relatively broad, low ridge, which can be traced some distance back toward the posterior extremity. In most cases two parallel linear grooves, often very distinct, proceed from the posterior extremity and, bounding 
the sides of the median ridge, seem to connect with the inner edges of the two oval scars. In one specimen these latter are rather distinctly seen to be duplicated by reason of a division longitudinal to their own greatest dimension, which is more or less transverse to the shell.

The correlates of these scars in Lingula anatina can not be positively determined. They have the general position and character of the scars which in the ventral valve of $L$. anatina are called centrals and externals, or external laterals. They are, however, relatively much larger. This denomination of them would leave unaccounted for the two middle laterals, which Hall and Clarke ${ }^{a}$ say are the most commonly retained in fossil forms. While not clearly distinguishable on any of the specimens examined, the presence of these scars may be indicated by the two linear grooves which pass down to the inner edges of the large oval scars. These may of course pertain entirely to the latter, but from the fact that both sides of these very narrow markings are equally sharp, it seems more likely that they mark the path of advance of a pair of small scars, rather than the course of only the edge of a pair of rather large ones, the major part of whose surface left no trace as it advanced. It is probably not unreasonable to consider as a hypothesis that the muscular bands of these earlier forms were less differentiated than in the later ones, and that the scars (and muscles) were to some extent combined so that, for instance, in the present form one portion of these double scars represents the combined centrals and externals of $L$. anatina, while the other represents the middle laterals.

In addition to the markings just described, which occupy the median portion of the shell, there are, at the sides, proceeding from the posterior margin and following the lateral outline, a pair of curved impressions whose inner border defines the sides of the shieldshaped visceral area. These are produced in the mold by two parallel furrows, leaving between them a rather narrow high ridge. They often appear like two ridges separated by a sulcus and empha sized on the inner margin by another similar sulcus; but the elevation which suggests a second ridge has no boundary on the outer side other than the edge of the shell. Of course on the shell itself these structures would appear as two curved ridges, inclosing between them an elongated impression, presumably to be interpreted as a muscle scar. This scar appears to be not single but double, a deflection on the inner ridge as seen on the shell causing an enlargement near the upper end, which, furthermore, is separated from the main scar by a . fairly distinct demarcation. Thus there is, apparently at the side

a Geol. Survey New York, Pal., vol. 8, pt. 1, 1892, p. 11.

46447 ${ }^{\circ}$-Bull. $439-10-3$ 
of the ventral valve, a very elongated double scar, the upper and inner one of the pair being considerably smaller than the lower.

There is a lack of uniformity about these impressions at the sides of the shell that makes their interpretation difficult. At first it might seem that they represent the combined transmedians and anterior laterals of $L$. anatina, the small upper portion being the transmedian and the large elongated one the anterior lateral; and perhaps this is the best interpretation. On the other hand, in the three best-preserved specimens the small upper scar is distinct on that side of the shell which would be the left in looking down upon the inside and apparently absent on the other. This asymmetry, if constant, exactly corresponds with the development of the transmedial muscle in L. anatina, and would strongly indicate that the scars in question belonged to that muscle alone, in spite of the fact that such an interpretation would leave the large anterior laterals without any distinct equivalent in the form under consideration. In point of fact, not only does the impression of a small upper scar seem to be absent or obscure upon the right side, but the larger one often appears reduced in size, the upper or posterior portion being atrophied, so that its shape and position are apparently changed.

In the posterior end of the ventral valve there are also markings whose character is less certainly muscular. This portion of the shell shows a shallow but distinct pedicle groove having transverse striations. It is bounded by narrow ridges, on either side of which is a sulcus (in the internal molds represented by a ridge) apparently continuing the depression of the elongated lateral muscle scars.

The vascular sinuses begin well-at the sides of the visceral area, swing strongly inward, and then forward, giving off numerous branches upon the outer side; which radiate to the shell margin.

In the dorsal valve the visceral area is longer and narrower, with a produced median portion. The principal impressions here are a pair of large oval scars situated not far from the median line, which may possibly be interpreted as the centrals of the dorsal valve of $L$. anatina. The forward extension of the visceral area would then be due to the same cause which produced a similar outline in the living form, the presence of a pair of anterior scars. The strongly marked topography in the present form is highly suggestive of a muscular imprint at this point along the median line, but a muscular scar is not clearly outlined, and certainly no indication of its duplicate character can be found in the specimens examined. On the other hand, several specimens show the impression of a pair of small scars close together, a little posterior to the large ones just described. If the latter are really the centrals, as first suggested, then these small impressions have no analogues in L. anatina, since from their size and median position they can hardly represent the two lateral 
groups of transmedian, external lateral, and middle lateral muscles. On this interpretation there is this further disagreement, when compared with $L$. anatina, that the relative sizes of the centrals and anteriors are reversed, and the centrals have a median instead of a lateral position. On the other hand, with the two large scars as the anteriors the pair of small ones slightly posterior to them could be interpreted as the centrals in spite of their median position; but the strongly elevated, sharply defined prominences at the projecting extremity of the visceral area would thus be put aside as without significance, which I think can hardly be safely done.

In the posterior portion of the dorsal valve a short distance in front of the edge there appears to have been, in most, if not all specimens, a depressed area which probably represents the site of muscular attachments. This area is small, deep, transverse, and of not entirely well-marked or constant shape. Often, however, it is distinctly trilobate on the inner side, the median lobe being smaller than the two lateral ones. This doubtless comes from the umbonal muscle, but that it was actually and regularly three fold in this species it would not be safe to say.

The vascular markings in this valve are similar to those in the ventral, but owing to the different shape of the visceral area, with its strongly projecting median portion, they are a little more marginal.

Most of the imprints shown by the specimens of $L$. batesvillæ are distinct and strong, and it is apparent from the foregoing discussion that they can not be satisfactorily homologized with the muscular imprints of $L$. anatina. If an essential agreement were found between other Paleozoic species and the type of structures found in $L$. batesvillæ, one would be justified in discriminating these ancient forms as a group distinct from Lingula; but, unfortunately, a disagreement equally strong is found between $L$. batesvillæ and other species of Paleozoic lingulas, some of which appear to be in much closer agreement with $L$. anatina. Some of this variation can doubtless be ascribed to the effects of preservation and the indefiniteness with which the muscles imprinted themselves on these usually rather tenuous shells, but probably there is considerable real variation between Paleozoic lingulas, as well as between fossil and living ones.

In fact, $L$. batesvillæ has much in common with the Cambrian lingulellas in the matter of internal scars, and is probably in as great or even greater agreement with that group than with $L$. anatina.

I have felt considerable hesitation about proposing $L$. batesvillæ as a new species, because it is similar to two Waverly forms, L. atra and $L$. cuyahoga. It seems, in fact, to be more or less intermediate between them, being somewhat narrower and more ovate than L. atra and somewhat broader than $L$. cuyahoga, though variation 
between different individuals of $L$. batesvillæ brings the extreme forms into close similarity with the two species mentioned.

L. cuyahoga, which is of the two perhaps the closest in shape, is said to be marked by fine striæ, which is probably not the case with $L$. batesvillæx. The latter, moreover, is characterized by having a very thick shell and a highly convex one. It is separated by a wide interval geographically from the Ohio form and associated with a very different fauna. The internal markings of $L$. cuyahoga and $L$. atra are unknown, so that comparison of this important group of characters can not be made. There thus seems to be a reasonable doubt whether $L$. batesvillæ is really the same as either of the Waverly species named, and since it is of especial interest, by reason of the unusually perfect manner in which the muscular impressions are retained, it seems that an identification which at the time it was made contained elements of reasonable doubt would be unfortunate. For these reasons a new name has been introduced.

This species in its abundance holds in the Moorefield fauna the same place which in the closely related fauna of the Caney shale is held by the form there called L. paracletus. It is by no means the same species, however, as the Caney one, being much smaller, and even in specimens of the same size possessed of a considerably different shape, which is relatively narrower and less ovate.

I do not attach much significance in the way of correlation to the resemblance of the lingulas of the Moorefield and Caney shales with those of the Waverly group. The Waverly is the only Mississippian fauna in which the lingulas are abundant and diversified, while the beds with whose faunas those of the Caney and Moorefield might more appropriately be compared contain these shells but rarely.

Horizon and locality.-Moorefield shale, Batesville quadrangle, Spring Creek (stations 1237R, 1248R4, 1248T, 1248Z, 2048, 2049c(?), 2049d).

\section{Lingula albapinensis Walcott.}

Plate I, figure 11.

1884. Lingula albapinensis. Walcott, U. S. Geol. Survey, Mon. 8, p. 108, pl. 2, fig. 1 .

Upper Devonian: White Pine district, Nevada.

1909. Lingula albapinensis. Girty, U. S. Geol. Survey, Bull. 377, p. 17, pl. 1, figs.6, $7,8(?)$.

Caney shale: Atoka, Antlers, and Ardmore quadrangles, Oklahoma.

Lingulas occur abundantly in the calcareous lower beds of the Moorefield shale, and nearly all the material collected belongs to the fine species which I have called $L$. batesvillæ. Two specimens obtained by Mr. Weller from station $1248 \mathrm{~A} 5$ seem to represent a distinct type. They are much smaller, have a somewhat different 
shape, lower convexity, and less massive shell. The two latter differences may be due in part to the small size and the occurrence in a sort of sandy shale in which leaching and compression may have occurred. The larger of the two specimens has a length of $10 \mathrm{~mm}$., while the smaller is $6 \mathrm{~mm}$. long. In both cases the shape is elongate-oblong, with greatest width near the middle or posterior to the middle, while in $L$. batesvillæ the greatest width is toward the front margin, with a gradual contraction of the outline posteriorly.

The surface appears to have been marked by regularly arranged incremental lines, with fine intermediate striæ.

It hardly seems advisable to unite these shells with $L$. batesvillæx, though coming from very nearly the same locality and horizon, nor can they be referred to the same species as that which, occurring in the closely allied Caney fauna, I identified as $L$. paracletus. They are, however, indistinguishable from the Caney form which I identified as $L$. albapinensis. In fact, the smaller of the two specimens from Arkansas is extremely similar, in such characters as can be ascertained, to the largest of the specimens figured from Oklahoma. The latter, however, is considerably larger than typical L. albapinensis, so that the largest specimen from Arkansas is many times the size of the type. Whatever bearing this may have upon the true identification of both occurrences, the Caney and Moorefield forms are, as now known, indiscriminable.

These shells recall a common variety of $L$. melie, but they represent a more slender type.

Horizon and locality.-Moorefield shale, Batesville quadrangle, Spring Creek (stations 1248A5, 2048, 2053).

\section{DISCINID E.}

\section{Genus IINGULIDISCINA Whitfield.}

In this place and elsewhere of late I am using Lingulidiscina for the group of shells which Hall and Clarke have called Orbiculoidea. The reason for discarding "Orbiculoidea" is that the first species named under the original description which, according to common practice must be regarded as the type, proves to be a Schizotreta.

Lingulidiscina is described as having its upper valve like Lingula and its lower valve typically discinoid. ${ }^{a}$ From the figures the lower valve does indeed seem to have a pedicle slit closed at the outer end just as in "Orbiculoidea." The upper valve with its nearly terminal apex also shows a configuration not alien to that genus, although a more central position is perhaps the rule.

Schuchert first made Oehlertella a synonym of Lingulidiscina, and then Lingulidiscina a synonym of Oehlertella, and it is evident 
that he regards them as the same type of structure. He also includes in the same group a form which I believe to be a characteristic "Orbiculoidea" (L. newberryi), that term being employed in this discussion in its current meaning. Schuchert's course regarding Oehlertella and Lingulidiscina may be due to one of several causes. He may hold that the peculiarity of the ventral valve, because of which Hall and Clarke separated Oehlertella from "Orbiculoidea," is due to breakage or some other accidental cause. In that case I would differ from him in believing that it was advisable to keep Oehlertella distinct from "Orbiculoidea." He may have determined that Lingulidiscina agrees with Oehlertella and that Whitfield was mistaken in describing and figuring the lower valve as being normally discinoid. In that case I should agree with him in uniting the two genera and in keeping them distinct from "Orbiculoidea"; and, of course, the employment of the term Lingulidiscina for the present group would be unjustified. I am now, however, assuming Whitfield's description and figures to be accurate, in which event Lingulidiscina becomes merely an "Orbiculoidea" with very eccentric apex, at least, so far as I can determine without examining specimens. I can not, therefore, regard Whitfield's reason for discriminating Lingulidiscina from the common discinoid (="Orbiculoidea") as being valid, but inasmuch as the group of shells commonly referred to "Orbiculoidea" appears, for reasons stated above, to be anonymous, it is possible to retain Whitfield's name and apply it to them. It is only provisionally, however, that I am using it in that sense; facts, which I at least have no means of determining, may show the premises upon which this course was adopted to have been false.

LINGULIDISCINA NEWBERRYI var. MOOREFIELDANA n. var.

Plate II, figures 6,7 .

Typical $L$. newberryi is rather imperfectly known, most of the citations usually met with, even those from Ohio, being referable to other species. The fossils under consideration are rather common in the basal calcareous beds of the Moorefield shale, but for some reason all the specimens examined except one are dorsal valves. They are characterized by a circular outline, rather small size (a diameter of $12 \mathrm{~mm}$. is about the maximum noted), and strong convexity. The apical portion is rather full and the apex itself often indistinct. It is situated one-fourth of a diameter or less in front of the posterior border. The surface is not well preserved in the specimens examined, but the sculpture appears to consist of the usual regularly spaced concentric lamellæ.

A somewhat similar species, and one which is suggestive because described from nearly the same locality and horizon, though in the 
latter respect from a little higher in the section, is Mr. Weller's L. batesvillensis. L. batesvillensis, judged by the figures, has a lower convexity and a relatively more marginal apex. In fact, I am disposed to believe it identical with typical $L$. newberryi.

Through the courtesy of the American Museum of Natural History I have compared the Arkansas specimens with the types of $L$. newberryi. Though closely related and more or less connected by intermediate forms, this variety shows rather well-marked differences from $L$. newberryi, besides coming from a different horizon and occurring associated with a different fauna. The typical specimens of $L$. newberryi vary considerably in the elevation of the dorsal valve, and they have, moreover, suffered more or less from compression. As a rule they are less strongly convex and of considerably larger size. The apex is also more marginal.

The Caney shale of Oklahoma has a related form, which I have described as $L$. newberryi var. caneyana. It appears under different conditions of preservation, being compressed in shale. It is hard to think of the Caney specimens, which are now quite flat, as having once had the rather high convexity of the form from the "Spring Creek limestone," and as at present seen the apex appears to be more mar-. ginal than in them.

Horizon and locality.-Moorefield shale, Batesville quadrangle, Spring Creek (stations 1248A12(?); 2048, 2049a(?), 2049b, 2049c(?)); Marshall quadrangle, Marshall (station 7038(?)).

LINGULIDISCINA NEWBERRYI var. MARSHALLENSIS n. var.

Plate II, figures $1,2,3$.

Shells belonging to the genus Lingulidiscina occur abundantly in the Moorefield shale at Marshall, but for some undetermined reason all the specimens obtained are dorsal valves. They resemble in a general way the form from Batesville described as $L$. newberryi var. moorefieldana but differ in having the dorsal valve less convex and its apex less marginal. The sculpture consists of somewhat irregular, closely arranged, subequal liræ, which are finer and fainter toward the apex.

It seems inadvisable to include these shells under the same title as the form from Batesville, and yet the two are very similar and apparently intergrade. A few specimens occur associated with typical $L$. newberryi, which can hardly, I think, be distinguished from the present form, except perhaps in point of size.. This form seems to differ from $L$. herzeri in having a more central apex and in having the liræ equal, or nearly so, instead of presenting, at irregular intervals, a few elevated strongly above the rest. 
Horizon and locality.-Moorefield shale, Batesville quadrangle, Spring Creek (station 2048(?)); Marshall quadrangle, Marshall (stations 7038, 7038c, 7039).

\section{LiNGULIDISCINA NEWBERRYI var. OVATA Girty?}

Plate II, figure 8 .

1909. Lingulidiscina newberryi var. ovata. Girty, U. S. Geol. Survey, Bull. 377, p. 20, pl. 1, figs. 9-11.

Caney shale: Antlers, Atoka, and Tishomingo quadrangles, Oklahoma.

The original fossils of $L$. newberryi var. ivata which came from Indian Territory are characterized by having a more or less strongly ovate outline. The only specimen which we have from the "Spring Creek limestone" (barring a small doubtful example) has this elongate shape in a marked degree. It is not possible to state definitely whether it is a dorsal or a ventral valve, but it seems to be a dorsal. As such the position of the apex is uncertain. It appears to be situated rather closer to the posterior margin than is the case in the Caney forms.

Horizon and locality.-Moorefield shale, Batesville quadrangle, Spring Creek (stations 1248A(?), 2053).

\section{IIINGUlidiscina NEWBerRyi var. caneyana Girty.}

Plate II, figures 4,5 .

1909. Lingulidiscina newberryi var. caneyana. Girty, U. S. Geol. Survey, Bull 377, p. 19, pl. 1, figs. 13-17.

Caney shale: Atoka, Tishomingo, and Antlers quadrangles, Oklahoma.

Associated in most cases with the form here described as $L$. newberryi var. moorefieldana, the fossils under consideration have been discriminated by reason of their lower convexity. In some cases this is possibly the result of compression and in others it might perhaps be looked upon merely as a variation; and in no instance are these shells abundant, well preserved, and mature (large). . Two specimens from station 2053 are flattened, and thus comparable to a form from the Caney shale which appears under the same title in a report on that'fauna. These shells are exactly like the Caney form. In them the apex appears to be slightly though distinctly more marginal than in typical L. newberryi or in the variety moorefieldana, with which they are associated.

The position of the apex of the dorsal valve has been used by others as I have used it, as a character of specific value, but it is evident that it is the proportional and not the actual distance of this point from the posterior margin that must be taken. In the dorsal valve: of this genus the increase by growth is always greater along the ante- 
rior than the posterior side, and while the apex is thus always in absolute measurement increasingly distant from the margin, it may well be asked whether this distance, proportional to the entire longitudinal diameter, remains constant. This fact is difficult to determine, but it has seemed to me that the ratio does often vary in proportion to size and usually in the way of the apex being more central in the young stages. Consequently, except in specimens of the same size, this character may prove misleading; and doubly so since one is unconsciously liable to be guided by the absolute rather than the relative position of the apex.

Horizon and locality.-Moorefield shale, Batesville quadrangle, Spring Creek (stations 1248A2, 1248R, 2048, 2049c, 2053), Moorefield (station 2051).

\section{PRODUCTID $A$ E.}

\section{Genus CHONETES Fischer-de-Waldheim.}

Chonetes sericeus Girty.

Plate II, figure 9.

1910. Chonetes sericeus. Girty, New York Acad. Sci., Annals, vol. 20, No. 3, pt. 2, p. 215 .

Basal Fayetteville shale: Fayetteville quadrangle, Arkansas.

This form is rather rare in the Moorefield shale; at Marshall, where alone it has been found, only nine specimens, some of them fragmentary, have been obtained. The size is medium or small, the largest specimen having a width of about $13 \mathrm{~mm}$. The shape is transverse, with the hinge line slightly longer than the width below. The dorsal valve seems to be almost absolutely flat, in the largest specimens somewhat curved outward toward the margin. The ventral valves found are fragmentary. Apparently they gained convexity rather by the height of the area than the curvature of the shell, which seems to have been depressed-pyramidal, gently rising to the somewhat prominent beak. On a small specimen three cardinal spines have been counted, while larger ones would probably furnish four or five.

The surface is crossed by fine, rather low and indistinct radiating liræ, which are obsolete near the cardinal angles. There are also fine, obscure transverse liræ, less equal, regular, and strong than those of $C$.illinoisensis, which this species especially resembles, and more suggestive of growth lines than those sharp crenulations. Like $C$. illinoisensis, however, the surface was probably sprinkled with rather small spines now evidenced by tiny openings or pores on the radiating liræ.

The form is clearly the same as that which occurs about Fayetteville in the basal part of the Fayetteville shale, and which, from specimens obtained there, I have described as $C$. sericeus. 
Horizon and locality.-Moorefield shale, Marshall quadrangle, Marshall (station 7039).

\section{Chonetes sp.}

It is a singular fact that no species of Chonetes has been as yet described from the upper Mississippian, and although the form under consideration belongs to that horizon I am in no position to remedy this deficiency, because it is represented in our collection by only two specimens, both of which are in an imperfect state of preservation. These specimens belong to the general type of $C$. flemingi and C. illinoisensis. They are small and transverse, having a length of $6 \mathrm{~mm}$. and a width of about $11 \mathrm{~mm}$. The median portions are inflated, a condition rather common in these transverse types, and there are no sinuses. The liræ are fine, about twenty-five in $5 \mathrm{~mm}$., and strongly crenulated. The number of spines is not known.

Horizon and locality.-Moorefield shale, Batesville quadrangle, Spring Creek (stations 2048, 2049c).

\section{Genus PRODUCTUS Sowerby.}

\section{Productus inflatus var. COlORADOENSis Girty?}

Plate IV, figure 3.

?1890. Productus boliviensis. Nikitin (non d'Orbigny), Com. Géol. [Ŕussia], Mém., vol. 5, No. 5, p. 57, 158, pl. 1, figs. $4 \mathrm{a}, 4 \mathrm{~b}, 4 \mathrm{c}$.

Gschelstufe: Near Moscow, Russia.

?1902. Productus inflatus. Tschernyschew (non McChesney), Com. Géol. [Russia], Mém., vol. 16, No. 2, pp. 261, 612, pl. 28, figs. 1-6.

Gschelstufe: Ural and Timan mountains, Russia.

1903. Productus inflatus. Girty (non McChesney), U. S. Geol. Survey, Prof. Papes 16, p. 359 , pl. 3, figs. 1-1b, 2, 2a, 3 .

Hermosa formation: San Juan region and Ouray, Colorado.

Weber limestone: Crested Butte and Leadville districts, Colorado.

Pennsylvanian: Glenwood Springs, Colo.

1904. Productus inflatus. Girty (non McChesney), U. S. Geol. Survey, Prof. Papes 21 , p. 52 , pl. 11 , figs. 5,6 .

Pennsylvanian (Naco limestone): Bisbee quadrangle, Arizona.

1910. Productus inflatus var. coloradoensis. Girty, New York Acad. Sci., Annals, vol. 20, No. 3, pt. 2, p. 215.

Basal Fayetteville shale: Fayetteville quadrangle, Arkansas.

This form is rare in the Moorefield shale. Our collections have furnished only five specimens, all ventral valves and all imperfect They show a rather large form of the normal semireticulatus type The convexity is high and the ventral surface broad, suddenly deflected at the sides and marked by a rather deep sinus.

The liræ are rather fine. In some specimens the transverse wrinkles are fine and numerous and in others coarser and much fewer. In one specimen there are two or three large spines along the 
hinge with a few small ones scattered over the surface. In another the spines along the hinge are smaller and more numerous. For the most part the character and arrangement of the spines is not shown and especially the diagonal row outlining the ears, which was noted in the specimens from the basal Fayetteville shale, has not been observed. It may, however, have originally been present, and it seems highly probable that this form is specifically identical with that from the Fayetteville shale which I provisionally identified with $P$. inflatus var. coloradoensis.

Horizon and locality.-Moorefield shale, Batesville quadrangle, Spring Creek (stations 1248Y, 2048, 2049c, 2049f).

\section{Productus arkansanus var. multiliratud Girty.}

Plate II, figures 10, 11.

1910. Productus arkansanus var. multiliratus. Girty, New York Acad. Sci., Annals, vol. 20 , No. 3, pt. 2 , p. 217.

Basal Fayetteville shale: Fayetteville quadrangle, Arkansas.

Under this title are included two large dorsal valves from the locality on Spring Creek near Batesville, Ark. The larger of these shells has a width of about $43 \mathrm{~mm}$. and a length of considerably less. The shape is transversely subquadrate, somewhat contracted at the hinge. The major part of this extent is nearly flat with a relatively narrow rim turned up rather abruptly about the front and sides.

The surface is marked by fine, irregular, discontinuous costæ and by very many fine irregular, rather inconspicuous concentric wrinkles. A mold of the exterior shows that there are also many small spines scattered over the surface, especially toward the margins, while in addition over the posterior portion there are a number of narrow elongated ridges resembling small appressed spines.

This shell is evidently not one of the normal semireticulati, this being shown by the inconspicuous concentric wrinkles, by the irregular radiating costæ, and especially by the presence of numerous spines upon the dorsal valve, structures which are very rarely developed on typical representatives of the semireticulate Producti. On the other hand, I believe it is closely related to the Keokuk form which Hall described as Productus setiger. From specimens obtained at Keokuk, which I believe to be referable to Hall's species, it differs in being smaller, in having the costæ finer and more continuous, and in having the spines less numerous. Further, in the Keokuk specimens the spines lie tangent to the surface, and in those from the Moorefield shale they are more nearly at right angles to it.

This seems to be the same species which I have described from the basal Fayetteville fauna as Productus arkansanus var. multiliratus.

Horizon and locality.-Moorefield shale, Batesville quadrangle, Spring Creek (station 1248Y). 


\title{
Productus pileiformis McChesney.
}

\author{
Plate IV, figures $1,2$.
}

1853. Productus cora. Shumard, Marcy's Expl. Red River, Louisiana, p. 202, Plate 1, fig. 1. (As a Senate Ex. Doc.)

Carboniferous: Washington and Crawford counties, Ark.

?1854. Productus cora. Shumard, Marcy's Expl. Red River, Louisiana, p. 176. (As a House Ex. Doc.)

Carboniferous: Washington and Crawford counties, Ark.

1855. Productus cora. Norwood and Pratten, Acad. Nat. Sci. Phila., 2d ser., vol. 3, p. 6.

Mountain limestone: Chester, Rosiclare, and Warsaw, Ill., near Richmond, Mo.; Carrsville, Ky.

1860. Productus pileiformis. McChesney, Desc. New Species Pal. Foss., p. 40. (Date of imprint, 1859.)

Kaskaskia division: Chester, Ill.

1863. Productus coræformis. Swallow, Acad. Sci. St. Louis, Trans., vol. 2, p. 94.

Archimedes limestone: Cooper County, Mo.

1891. Productus pileiformis. Whitfield, New York Acad. Sci., Annals, vol. 5, p. 582, pl. 13, figs. 13, 14.

Maxville limestone: Ohio.

1895. Productus pileiformis. Whitfield, Geol. Survey Ohio, Rept., vol. 7,- p. 470, pl. 9, figs. 13, 14. (Date of imprint, 1893.)

Maxville limestone: Ohio.

1896. Productus cora. Smith (pars), Am. Phil. Soc., Proc., vol. 35, p. 238.

Archimedes limestone: Independence County, Ark.

Marshall shale: Independence and Stone counties, Ark.

Fayetteville shale: Independence County, near Moorefield, Ark.

1896. Productus cora. Smith (pars), Leland Stanford Junior Univ. Pub., Contrib. Biology Hopkins Seaside Lab., No. 9, p. 28.

Archimedes limestone: Independence County, Ark.

Marshall shale: Independence and Stone counties, Ark.

Fayetteville shale: Independence County, Ark.

1909. Productus pileiformis. Girty, U. S. Geol. Survey, Bull. 377, p. 26, pl. 2, fig. 7. Caney shale: McAlester quadrangle, Oklahoma.

The shells from the Moorefield shale closely resemble $P$. pileiformis, not to mention $P$. lævicosta, both Mississippian types, and $P$. cora of the Pennsylvanian. The ventral valve is variously shaped, depending upon age, individual peculiarities, and deformation by compression. It is moderately inflated, sometimes wider than long, with a rather wide apical angle. The dorsal valve is flatter with a considerably less prominent beak.

There are the usual large strong wrinkles on the ears and sides, often restricted to those areas, but sometimes extending more or less distinctly from side to side, especially in the dorsal valve, and but seldom, if ever, occurring over the anterior portion of either. The costæ are fine, rather rigid, often alternating by reason of new ones introduced by intercalation. Fourteen to sixteen or more occur in the space of $5 \mathrm{~mm}$. Spines seem to be rarely developed, though an 
occasional one of large size may be noted. There are rather strong concentric crenulations.

As distinguished from most species of the cora group the present form has a rather thick shell and retains fairly strong, though not sharply defined, muscular imprints. When exfoliated, these thick shells lose all trace of radiating liræ and show instead an apparently smooth surface crossed only by fine irregular intersecting transverse crenulations. No specimens entirely exfoliated have come to hand, but in that condition this form must sometimes closely simulate the widely different Productella hirsutiformis. It is true that the latter species has numerous spines, which, however, being always broken off, are seldom obvious, and as a rule a lower convexity; but in one instance a partly exfoliated example of $P$. pileiformis among our specimens seems at first to be made up of a valve of $P$. hirsutiformis with a broken ventral valve of $P$. pileiformis crushed down upon it. A careful inspection of the specimen, however, shows that this is not the case, an inference which is strengthened almost to a certainty by other exfoliated specimens. On the other hand, P. hirsutiformis, as here identified, is not based upon the exfoliated specimens of $P$. pileiformis, a fact clearly demonstrated by examples which retain the outer shell layers with little, if any, exfoliation, and by numerous external molds.

Mention is important at this point of a dorsal valve of $P$. hirsutiformis preserved as an external mold, which has otherwise all the characters of other dorsals of the same species, except for the possession of faint but unmistakable fine, radiating liræ, and so must have been very like the dorsal valve which presumably belonged with the specimen of $P$. pileiformis especially mentioned. This is the only instance observed of well-marked radiating liræ in P. hirsutiformis, though in other specimens from the same locality traces of them can be made out, presumably connected with the development of rows of internal spinules. These facts are at least suggestive of an intergradation between these at first sight widely unlike types, and of a possibility that exceptional specimens might be difficult to refer to one species rather than the other.

I was at first so much impressed by the apparent tendency of these shells to grade into $P$. hirsutiformis, as well as by such differences from typical $P$. pileiformis as the (sometimes) transverse shape, wider apical angle, and thicker shell, that I intended to introduce a new name for the Moorefield specimens, but upon reconsideration it seemed that the thick test and the unusual appearance when exfoliated, which is after all their most constant and striking peculiarity, was not a valid ground for discriminating them from McChesney's species. Some specimens no one would think of distinguishing from 
Productella pileiformis, and it seems improbable that they are really distinct even from the specimens which show the most important differences from them. Nevertheless, these shells in the Moorefield certainly manifest rather noteworthy peculiarities.

Horizon and locality.-Moorefield shale, Batesville quadrangle, Spring Creek (stations 1248R, 1248R4, 1248Rx, 1248Y, 2048, 2049a, 2049f, 2053); Marshall quadrangle, Marshall (station 7038a).

\section{Productus Biseriatus Hall.}

Plate III, figs. 10, 11 .

1856. Productus biseriatus. Hall, Albany Inst., Trans., vol. 4, p. 12.

Warsaw limestone: Alton, Ill.; Bloomington, Ind.

1882. Productus biseriatus. Whitfield, Am. Mus. Nat. Hist., Bull., vol. 1, p. 46, pl. 6, figs. 8-12.

Warsaw division: Spergen Hill, Paynter's Hill, and Bloomington, Ind.; Alton, Ill.

1883. Productus biseriatus. Hall, Dept. Geology and Nat. Hist. Indiana, Twelfth Rept., p. 325, pl. 29, figs. 8-12.

[Warsaw limestone]: Alton, Ill.; Spergen Hill, Paynters Hill, and Bloomington, Ind.

1895. Productus biseriatus. Keyes, Missouri Geol. Survey, Rept., vol. 5, p. 43. (Date of imprint, 1894.)

Keokuk limestone: St. Francisville, Mo.; Keokuk, Iowa.

1906. Productus biseriatus. Beede, Dept. Geology and Nat. Res. Indiana, Thirtieth Ann. Rept., 1905, p. 1299, pl. 22, figs. 8-12; pl. 19, fig. 6 .

Salem limestone: Spergen Hill, Bedford, Harrodsburg, Bloomington, Ellettsville, and Stinesville, Ind.

The fossils included in the present group are abundant at several horizons in the Moorefield shale, but our specimens are for the most part dorsal valves. They are small (the largest having an indicated width of $12 \mathrm{~mm}$.), transverse, subquadrate. The front and sides are regularly rounded, the latter contracting slightly toward the hinge. The ventral valve is rather strongly convex with a narrow incurved beak, while the dorsal is gently concave, more or less strongly arched about the margin. Preserved as external molds, the condition in which most are presented to view, the surface of the dorsal valve is marked by five or more elevated concentric bands separated by rather sharp deep striæ and by fine incremental striæ. There are also numerous spines of two sizes, distributed transversely over the bands. In the ventral valve the surface is similarly banded, the plications which separate the bands being often quite angular.

These shells are probably identical with $P$. biseriatus. Some differences can be distinguished between specimens; for instance, it appears that the bands on the present form are divided by more angular folds, that the smaller spines are relatively not so small nor so numerous, and that the interval above the rows of spines is narrower and 
less strongly striated, etc. These characters vary, however, in both sets of fossils studied-those from Arkansas and those from Indiana, Missouri, and Illinois-and I believe that the differences are in part due to the fact that the specimens from Arkansas are rather small, while the best of the others are rather large. From the evidence available, therefore, the separation of the Arkansas shells from $P$. biseriatus would not be justified.

Horizon and locality.-Moorefield shale, Batesville quadrangle, Spring Creek (stations 1248R4, 2048, 2049a, 2049c).

\section{Productus subsulcatus n. sp.}

Plate III, figs. 12, 13, 14.

Shell rather small, subquadrate, somewhat transverse.

Ventral valve rapidly enlarging, moderately elevated and arched. Cardinal angles quadrate; ears small, depressed; sinus absent.

Surface marked at rather distant and regularly increasing intervals by concentric striæ, which divide the shell into broad transverse bands. There are are also delicate, more or less irregular striæ of growth. Costæ appear to be altogether absent, though there are a few irregularly disposed radiating striæ. The entire surface is rather plentifully sprinkled with small spines which tend to arrange themselvies in transverse series chiefly near the striæ. The spines are small and spring from the shell without producing elongate bases or producing only faint ones: There is, however, a variety of this species in which the spine bases are conspicuously elongated.

The dorsal valve is very slightly concave over the visceral area, more strongly curved marginally. The ears are small and quadrate. As seen on molds of the exterior the sculpture, as in the ventral valve, consists of regular transverse bands separated by narrow striæ and of fine incremental striæ. The spines are numerous, small, and arranged more or less in transverse rows.

The cardinal line seems to be linear and the generic position has been provisionally determined as Productus instead of Productella.

This species is most closely related in the present fauna to Productella hirsutiformis, from which, however, it is clearly distinct, being smaller and more highly arched and characterized by different surface characters. The regularly banded sculpture is not found in $P$. hirsutiformis, which has fewer spines on the ventral valve and none at all or very few on the dorsal. $P$. subsulcatus also resembles $P$. indianensis, from which it is distinguished by its larger size, its broader shape, and its less prominent beak.

Horizon and locality.-Moorefield shale, Batesville quadrangle, Spring Creek (stations 1248A1(?), 1248A2, 1248A5, 2049). 
Prodects stbsticates var. Jants n. var.

Plate 111, fig. 15.

A few specimens from station $1248 \Lambda 5$ are to a certain extent intermediate between $P$. subsulcatus and $P$. moorefieldanus, but they can not be identified with either form without appearing rather obviously incongruous. They are ventral valves and have the large size, spreading shape, and low convexity of $P$. subsulcatus. They have a similar sculpture also, but the transverse bands are less regular and less distinct and the spines are mounted on prominent elongated bases. From I'. moorefieldanus this form diflers in its broader, lower shape and in having the spine bases less elongate and more regularly arranged in transverse rows.

IIorizon and locality.-Noorefield shale, Batesville qualrangle, Spring Creek (stations 124\$A5, 2048(!)).

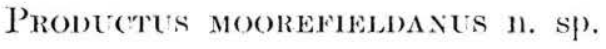

Plate III, figure ti.

Shell small, subquadrate, slightly transverse. Tentral valve strongly arched, rapilly expanding. Ears very small, quadrate, and undefined. Sinus absent.

Surface marked by rather strong, regular, closely arranged transverse strix. Costae probably absent, though toward the front a few slender, irregular, widely separated ribs are developed. Spines, small and fairly numerous, are scattered over the surface, arising from the anterior end of elongated bases, themselves appearing like appressed spines, which toward the front are prolonged into slender costæ.

Dorsal valve unknown.

Without actual comparison of specimens this form might readily be mistaken for Productus concentricus of the Chouteau limestone. The typical specimen is larger than $P$. concentricus from the Chouteau itself. but of about the same size as larger representatives of the species from the lower Burlington. The chief claim to distinction, so far as the ventral valve is concerned, resiles in the sculpture, which, though the same in general character, differs in detail. The spines are smaller, as are also the occasional costce, and there are more of the slenter elongated spine bases.

I am somewhat in doubt also as to the relation in which this species stands to P. subsulcatus, with which it is associated and to which it is in many respects similar. In comparison with that species the type specimen of $P$. moorefieldanus is smaller and more highly arched. It lacks the transverse sulci and bands of $P$. subsulcatus, though these characters are especially obvious in the dorsal valve, whose characters in $P$. moorefieldanus are not known. The spines are also less numerous 
and not so regularly arranged; they spring from elongated bases, in this respect resembling the variety janus more than $P$. subsulcatus itself. There is in the Survey collection, however, a second specimen which has the small size and convexity(?) of $P$. moorefieldanus and the sculpture of $P$. subsulcatus. At least it bears one transverse sulcus with small spines, perhaps more as in $P$. moorefieldanus. This specimen is imperfect and its characters not clearly shown so that it is perhaps not as intermediate as now seems to be the case. More abundant and better specimens of both species will be required before the relationship subsisting between them can be satisfactorily determined, but it seems probable that $P$. moorefieldanus will prove at least a good variety. Of course, if it develops that $P$. moorefieldanus possesses characters allying it closely with $P$. subsulcatus it is so much the more strongly distinguished from $P$. concentricus.

This form belongs to the same group as $P$. indianensis. The Survey has some specimens from Mooresville, Ind., supposed to belong to Hall's species, that attain the size of the present one. They have much more numerous spines, especially in the mature condition.

Horizon and locality.-Moorefield shale, Batesville quadrangle, Spring Creek (stations 1248A12, 1248R5(?), 2049, 2049b(?)).

Productus moorefieldanus var. pusillus $n$. var.

Plate III, figures 7, 8, 9.

The shells here considered are little more than a small variety of $P$. moorefieldanus, but they are very much smaller, from one-half to one-third the size of that species.

The ventral valve is moderately convex, subquadrate in outline. The surface markings consist of fine concentric striæ and concentric wrinkles which vary much in number and intensity in different specimens, and are strongest toward the ears. Small spines are also scattered over the surface, springing from bases which are usually slightly elevated and slightly elongated.

The dorsal valve is subquadrate, moderately concave, arched especially about the margin. There are concentric striæ and wrinkles, a few of the latter being often more prominent and angular than the rest. A few spines are developed, especially toward the margin. Sometimes they are almost absent. There are also relatively large circular depressions or pits, probably correlated with spines developed on the other valve, in some specimens few and in others rather numerous.

These shells resemble $P$. biseriatus, but differ from it in having the wrinkles less numerous, regular, and angular, and in having the $46447^{\circ}-$ Bull. $439-11-4$ 
spines much fewer, of uniform size, and of much less regular distribution. I'. indianensis seems to be a very similar form but the spines in the present species are less numerous and less regular, and the wrinkles are also less regular. These differences are indicated by IIall's description and figures. A few specimens from Mooresville, Ind., supposed to belong to $P$. indianensis, differ from the Arkansas form in having less strong wrinkles and more numerous spines, especially over the umbonal region. To distinguish this form from young shells of $P$. moorefieldanus, $P$. subsulcatus, etc., will not always be easy. The greater convexity, which indicates that the specimens under consideration are really mature, will serve to this end.

IIorizon and locality.-Moorefield shale, Batesville quadrangle, Spring Creek (stations 1248A6( ?), 1248R4, 2048, 2049, 2049a, 2049c).

Subgenus PRODUCTELLA Hall.

Pronectella hirsutiformis Walcott.

Plate III, figures 1-4.

1884. Productella hirsutiformis. Walcott, U. S. Geol. Survey, Mon. 8, p. 133, pl.2, fig. 10.

Upper Devonian: Eureka and White Pine districts, Nevada,

1909. I'roductella hirsutiformis. Girty, U. S. Geol. Survey, Bull. 377, p. 24, pl. 2, figs. $4-6$.

(aney shale: Ardmore, Atoka, and Tishomingo quadrangles, Oklahoma.

This species is common in the "Spring Creek limestone" and is characteristic of its fauna. The shells referred to it are rather large, transverse, subquadrate, both valves having a low convexity with ears which are not well defined nor large. The beak of the ventral valve is small and depressed.

The surface of the ventral valve is marked by fine concentric striæ and larger wrinkles. There are also fairly numerous and rather small spines scattered over the surface with a single or double row of somewhat larger ones along the hinge. The inner surface is thickly covered with little spinules which are more closely and regularly arranged near the margin, producing upon internal molds the effect of fine, irrecular striation. Upon exfoliated shells the spinules appear like scattered punctro.

In the clorsal valve the surface is essentially the same as that of the ventral, except that there are no spines. Costr are usually entirely absent from both valves. Rarely do the spines of the ventral shell rise from the lower end of elongate spine bases, though a few instances have been noted where evanescent, coarse ribs have been thus produced. In the dorsal valve the corresponding costæ are represented by grooves. In a single instance a valve of this species, which is 
almost certainly a dorsal, shows upon the external mold distinct traces of fine, unequal and irregular radiating costæ. This anomalous character seems to indicate an intergradation, with Productus pileiformis.

The shell is thin, but thick enough over the posterior portion to retain distinct though ill-defined impressions of muscular attachment.

Both valves possess a relatively wide cardinal area, and this fact, together with the configuration and the sculpture, seems to warrant assigning the species to the subgenus Productella.

Lot 2049a contains what appears to be a variety of the species associated, however, with the normal form. It is distinguished by having a very transverse-shaped extended hinge, angular depressed ears, and a somewhat inflated median portion.

The typical variety appears to be precisely the same form which occurs in the Caney shale in Oklahoma, and which I cited under the same name in describing that fauna.

Horizon and locality.-Moorefield shale, Batesville quadrangle, Spring Creek (stations 1248A1, 1248A2, 1248A5, 1248A6, 1248R4, 1248R5(?), 1248Y, 1248V, 2048, 2049, 2049c, 2049f(?), 2053), Moorefield (station 2051a).

\section{Productella hiRsutiformis var. Batesvillensis n. var.}

Plate III, figure 5.

A few specimens from station 2049A differ from typical $P$. hirsutiformis in being smaller, longer on the hinge, and with an inflated middle portion. The spines also appear to be less numerous. The ears are rather large and triangular. In its general configuration this form is very suggestive of $P$. adairensis, which is such a common and characteristic fossil of the basal Fayetteville shale. It is, however, readily distinguishable by being without a sinus and by lacking the costæ, which, though sometimes rather faint, are a constant feature of that species.

Horizon and locality.-Moorefield shale, Batesville quadrangle, Spring Creek (station 2049a).

\section{Subgenus DIAPHRAGMUS Girty.}

\section{Diaphragmus elegans Norwood and Pratten.}

Plate IV, figures 4, 5 .

1854. Productus elegans. Norwood and Pratten, Acad. Nat. Sci. Philadelphia, Jour., 2d ser., vol. 3, p. 13, pl. 1, figs. 7a-c. (Not P. elegans McCoy.)

Mountain limestone: Chester and Kaskaskia, Ill.; near Hat Island, Missouri.

1860. Productus cestriensis. Worthen, St. Louis Acad. Sci., Trans., vol. 1, p. 570.

Chester limestone: Chester, Ill. 
1877. Productus elegans. Hall and Whitfield, U. s. Geol. Expl. 40th Par., Rept., vol. 4, p. 268 , pl. 5 , figs. 3 and 4 .

Lower Carboniferous limestone: North of Snowstorm Hill, Dry Canyon, Oquirrh Mountains, Utah.

1891. Productus clegans. Whitfield, New York Acad. Sci., Annals, vol. 5, p. 581, pi. 13 , figs. $15,16$.

Maxville limestone: Ohio.

1895. Productus cestriensis. Keyes, Missouri Geol. Surv., Rept., vol. 5, p. 44. (Date of imprint, 1894.)

Kaskaskia limestone: St. Mary, Mo.

1895. Productus elegans. Whitfield, Geol. Survey Ohio, Rept., vol. 7, p. 469, pl. 9, figs. 15, 16.

Maxville limestone: Ohio.

1897. Productus cestriensis. Weller, New York Acad. Sci., Trans., vol. 16, p. 256, pl. 19, figs. 7-9. (Date of volume, 1898.)

Batesville sandstone: Batesville, Ark.

This species occurs in but one of the Survey collections from the Moorefield shale, but in it it seems to be reasonably abundant, eight specimens having been obtained. In its specific characters it is not quite typical, but the differences are not such, in my judgment, as would warrant discriminating it as a variety, especially as the different individuals vary considerably among themselves. The points in which this form is thought to vary from typical $D$. elegans are its large size and spreading shape, its somewhat stronger and more regular liræ, and the inferior development of spines.

The shape of the ventral valve, as remarked, is similar to that of $D$. elegans, but is broader and rather more spreading. An illdefined but distinct sinus is a constant character. The liræ are strong, rigid, and rather fine, about eleven in $10 \mathrm{~mm}$., but in one specimen they are finer, sixteen in $10 \mathrm{~mm}$. Sometimes also they are rather irregular and nodose. There are relatively strong and coarse crenulations. Fine, indistinct wrinkles cross the posterior portion. Fairly numerous though fine spines are distributed over the surface, but they do not make conspicuous nodes on the liræ, and are easily overlooked when broken off. They occur thickly on the ears and adjacent to them.

The dorsal valve is gently concave over the visceral region, more strongly curved about the margin, with small recurved ears. The cavity between the two valves is rather high. The liræ are moderately strong and crossed by fine, faint concentric wrinkles. Strong varices of growth are perhaps a characteristic feature of the dorsal valve, which is not well represented in our collection. This valve shows the internal plate characteristic of the subgenus Diaphragmus.

This same form occurs also in the basal Fayetteville shale of northwestern Arkansas. While the smaller, narrower form is more abun- 
dant there, specimens quite comparable to those of the Moorefield shale are not lacking.

Horizon and locality.-Moorefield shale, Batesville quadrangle, Spring Creek (station 1248R4).

ORTHID A.

Genus RHIPIDOMELLA Oehlert.

RHIPIDOMELLA ARKANSANA n. sp.

Plate II, figures 14, 15, 16.

Shell of medium size, rather strongly transverse. Maximum length observed $24 \mathrm{~mm}$. Shape subquadrate, hinge line rather long and straight, two-thirds the entire width or a little less. Cardinal angles distinct. Area low. Beak small, slightly projecting, that of the ventral valve the more prominent. The two valves are nearly equally convex, the ventral being somewhat the more so.

Ventral valve with a narrow and deep though indistinct sinus. Dorsal valve without any fold distinct from the usual convexity, but sometimes, at least, with a narrow indistinct sinus also. As a result the front outline is broadly emarginate.

Surface marked by rather fine subequal liræ, nine to thirteen in 5 $\mathrm{mm}$. The liræ show the usual tubular openings, though rather sparingly. On the interior of the ventral valve the muscle scar is small, deeply imprinted, flabelliform, and it occupies a little less than half the length. In the dorsal valve the scar is similar in a general way but fainter and somewhat longer and narrower.

There are other associated examples which do not show the peculiarities of configuration as strongly as the typical ones, but they are in some cases young specimens, and in others fragmentary ones. Still it seems probable that all did not have the ventral sinus as strong as in those figured.

This is without much question a distinct species from $R$. burlingtonensis, from which it differs in its more transverse shape, deeper sinus, and less prominent ventral beak; similar differences exist between it and other Mississippian Rhipidomellx. The dubia group has a pentagonal and narrower shape with larger more prominent beaks. From the oweni group $R$. arkansana differs in the depth of the ventral sinus. Perhaps the nearest of all is Swallow's Orthis clarkensis, but the form under consideration is associated with a very different fauna, and I would not venture to identify it with Swallow's poorly described and unfigured species.

Horizon and locality.-Moorefield shale, Batesville quadrangle, Spring Creek (stations 2048, 2049a, 2049c). 


\section{RHYNCHONELIID $A$.}

\section{Genus LIORHYNCHUS Hall.}

\section{LIORHYNCHUS CARBONIFERUM $11 . \mathrm{sp}$.}

Plate VI, figures 1-8, Plate VII, figures 13-16.

1877. Leiorhynchus quadricostalus? Meek, U. S. Geol. Expl. 40th Par., Rept., vol. 4, p. 79, pl. 3, figs. 9-9b.

Carboniferous: White Pine Mountains, Nevada.

1909. Liorhynchus aff. mesicoslale. Girty, U. S. Geol. Survey, Bull. 377, p. 26, pl. 2, figs. 11, 12 .

('aney shale: Atoka quadrangle, Oklahoma.

The shells included under this title are abundant in the Moorefield shale both at Batesville and at Marshall, though the specimens thus far obtained at this horizon from the latter place are all considerably undersized. They show great variation in all characters, although perhaps this appearance of unstability is enhanced by the more or less incomplete, compressed, or imperfect condition in which many specimens are preserved.

L. carboniferum attains a large size, a length of $32 \mathrm{~mm}$. being about the maximum. The shape is generally oval, but much diversity is shown in the proportion of length and width, some examples being long and narrow and others short and broad, with intermediate conditions. The shape also varies toward the pentagonal or even the triangular according to whether the greatest width is attained abruptly and is situated near the front or back from it. The fold and sinus are high in mature shells, but they extend only about half way to the beak and are consequently developed imperfectly or not at all in the immature condition. The costæ vary greatly in number, size, position, and strength. Usually they are rather faint and are restricted to the mesial portion, to the top of the fold, and to the bottom of the sinus, which features do not normally bear plications on their sides. The plications do not extend to the beaks but they are more persistent than the sinuation. Generally speaking, when the plications are numerous they are small, and when they are few they are large. They are more or less equal and seldom bifurcate.

Normally, or perhaps I should say more commonly, there are four plications on the fold, three in the sinus and no lateral ones, but sometimes instead of four large plications there are five, six, seven, or even eight fine ones. The occurrence of only three costæ on the fold seems to be rather rare. The number of plications is probably not a specific character, and, at all events, is hardly available for discriminating species, because the costæ are apt to be faint and difficult to count, perhaps one or two less distinct than the others and doubtful. Furthermore, a few specimens have been noted which appear to 
have more numerous costæ in the young condition than on the mature portions of the shell. This is probably due to the development in early stages of lateral costæ, which became obsolete toward maturity. Occasionally the plications are so faint that the shell appears to have been almost noncostate; and, in fact, this character, considered as a whole, seems to be the result of a tendency toward obsolescence of the . costæ in a plicated shell, the tendency being manifested more on the lateral areas than on the mesial one and more in mature than in youthful stages.

While the test seems to have been thin and fragile over the anterior parts, it was much thicker near the beaks, and the muscular markings are often well shown. The internal structures appear to be identical with those of Liorhynchus. In the ventral valve there were two dental plates which did not meet the shell squarely as in Dielasma, but somewhat convergingly, and they join it without an angle. The space between the plates and the shell is more or less completely filled in with testaceous material. In the interior of the ventral valve, therefore, there is a triangular area excavated as it were in the thickened posterior portion. Its lower limit is sharply defined by the ends of the dental plates, which may or may not be consolidated with the rest of the shell. It is transversely corrugated, probably owing to muscular attachment. At its bottom is a groove rather abruptly sunk, which rapidly enlarges toward the front and is more definite in some specimens than in others. It transects the ridges which bound the apical triangle on its lower side and widens out below in a shield-shaped scar whose anterior end lies about midway of the length of the valve. This scar has a distinct outline, being surrounded by a ridge which is continuous above with the ridges defining at the sides the lower border of the triangular area in the apex. The median portion of this shieldshaped scar is occupied by two elongated oval scars surrounded by it and slightly depressed below its general level. The foregoing description is based on the most strongly characteristic specimen examined, but others have similar muscular imprints, though less well marked and in some cases more or less modified.

In the dorsal valve there is a fairly high median septum connected at its upper end with the hinge plate and reaching half the length of the valve, more or less. It is thickest toward its posterior extremity, where it coalesces with the hinge plate, which bears a short sulcus, widest about where the septum joins the plate and contracting in either direction. Thus a sort of diminutive spondylium is formed. In one or two instances the septum was seen to connect with the hinge plate slightly to one side of the center, while from a corresponding position another thin plate extended into the cavity of the shell. From this abnormal specimen it would appear that the septum, posteriorly at least, is possibly made up of two coalesced plates. It 
is conceivable that these two plates represent the crura, but this is thought to be very improbable.

The eenter of the hinge plate has already been described as depressed into a triangular pit whose sides are made by strongly and sharply elevated ridges. Another similar ridge, though much longer, divides what remains of the hinge plate on either side, and, bending around at the end, forms a socket into which a corresponding tooth of the ventral valve is locked. The sockets are crenulated. Still another feature of the hinge plate may be mentioned at this place, namely, that its posterior portion is often distinctly marked by transverse stria. The striated area is usually sharply outlined, sometimes by an elevated ridge, and it extends in the maximum to about half of the height of the plate.

Near the middle of this valve and with a length of one-half to one-third of the whole is an clongated muscular area which is divided longitudinally by the median septum. Fach narrow segment gave lodgment probably to two muscles. A large clearly defined scar occupies the lower part of each division, and markings of a somewhat doubtful character possibly indicate the position of a smaller scar in the upper part.

One stratum of no great thickness at the Spring ('reek locality contains young specimens of this and several other species in considerable abundance. The preservation is peculiar, the fossils having a black lustrous appearance such as we commonly associate with a phosphatic composition. This appearance, however, is due to some peculiarity on the inner layers of the shell or perhaps to some secondary deposit upon the inner layers, the shell itself being white and evidently nonphosphatic, as is normal to this group. This shiny appearance is found only on the inner side of the shell, but is probably not due to secondary or chemical deposition. It has been noted occasionally on the inner layers of the apical portion of mature Liorhynchus found in the same bed, but not on the rest of the surface nor on large shells like Productus. It does, however, occur in other small shells, such as Ambocolia lovicula and young Moorefieldella eurekensis. Another appearance accompanies the peculiarity above mentioned in these young Liorhynchus, for upon the shiny surface of the internal mold are minute but very distinct markings, which strongly suggest a punctate shell structure. After careful consideration of the subject it has seemed to me probable that this appearance is due to the contact of this phosphatic (?) layer with the oblique fibers which normally make up the shell in this genus. This inference is further borne out by the fact that a similar appearance of punctation is found upon internal molds of Ambocolia lævicula, whereas it has not been noticed upon molds of the apical portion of mature Liorhynchus, where the fibers run parallel to the sides of the dental plates. Of course, if this 
species really possesses an inner phosphatic punctate layer, it is distinct, not only specifically but generically, from the Chemung species, to which it has generally been considered to be allied.

These small shells show the essential structures of the large ones, a median septum in the dorsal valve and two dental plates in the ventral, often at a size of 2 or $3 \mathrm{~mm}$. (in length). The muscular system also seems to be in accord with that of the mature condition, though in the mature shells the impressions of the ventral valve are more strongly marked and more persistently preserved, while in the young ones the dorsal-valve impressions are most commonly and sharply retained. Where an exceptional specimen retains the ventral scars they are quite analogous to those of the mature condition. Similarly in the dorsal valve the muscles were attached in two sharply defined, rather deeply sunk elongated areas extending down the septum on either side near the middle of the valve, and in some instances there is fairly good reason for recognizing an upper and a lower pair of muscles. Other characteristic features, however, are wanting. The shape is oval, the convexity of both valves is low, and the dorsal instead of the ventral bears a sinus which is in some cases rather strong. It is probably true that all costate brachiopods, at all events all rhynchonelloid brachiopods, if found at a sufficiently early stage would be without costæ, and the very young among the present specimens seem to lack that feature. At 4 to $8 \mathrm{~mm}$. and more, the plications, where present, can usually be plainly seen. In some cases one can not be sure whether the specimen is costate or not, so faint are the markings, and in many others the costæ are restricted to the mesial portion; but it seems indubitable that a much larger proportion of these young shells are costate all the way around than one would expect from the number of mature shells showing this character. This seems to suggest that many young examples which are completely costate in their early stages become smooth laterally when they reach maturity and perhaps that these shells are lapsing from a strongly plicated type rather than developing into one, which indeed has been commonly considered to be the case.

Although this form has heretofore always been identified with one or another of several Devonian species, and although in a previous paper I myself compared what is without much question the same form in Oklahoma with the Chemung Liorhynchus mesicostale, I have now little doubt that it is really a new species. It was impossible to determine this from the Caney specimens, although general considerations of age and faunal association made it highly probable, but such a conclusion seems hardly avoidable from a study of the far more abundant and better-preserved fossils from the Moorefield shale. Aside from the difference in geologic age, faunal association, and distribution, this form differs from L. mesicostale, which seems 
to be the most closely allied species, in being more convex, in being apparently a heavier and more massive shell, and in having the plications less sharply defined, less bifurcating, and less unequal. The dorsal valve is narrower and more pointed posteriorly and has a larger and somewhat differently modeled hinge plate. Both species vary so widely, however, that these differences will probably not be found to subsist between all specimens, but, in view of other differences rather more extrinsic, it appears to be wiser to discriminate the Carboniferous species rather than to ilentify it with the Devonian one.

In generic position I believe this to be a true Liorhynchus and know of no characters adverse to such a conclusion save the phosphatic and punctate appearance of the young stage, which is believed to be entirely adventitious. The occurrence of Liorhynchus in the Carboniferous, however, is not as isolated as might at first appear. Hall and ('larke mention $L$. greenianum from the "Knobstone" and L. boonense from the Burlington (though they figure L. greenianum as a Pugnax). I mysell described $L$. haguei from the western Carboniferous, and I believe that some of the Mississippian pugnaces of the type of $P$. missouriensis possess a septum too well developed to be advantageously lodged with Pugnax. They are at all events intermediate between Pugnax and Liorhynchus.

It is highly probable that these Arkansas shells are specifically identical with those from the White Pine shale of Nevada, which Meek identified as Liorhynchus quadricostatum Vanuxem?. As he stated in his report, ${ }^{a}$ Neek had in manuscript proposed a new name for the Nevada form, but withdrew it as his work was passing through the press beeause Hall and Whitfield, who had examined material from the same formation and had enjoyed an opportunity of comparing it with authentic specimens of the New York shell, believed the two to be idlentical. The name which Meek had intenderl to impose on that form is not stated, but can be inferred from a paper by $\mathrm{King},{ }^{b}$ in which, in listing the fossils from the White Pine shale (the specific (leterminations being made by IIall and Whitfield), he cites Leiorhynchus quadricostatus IIall=Rhynchonella (Leiorhynchus) papyracea Meek.

Prolessor Williams has remarked, "If a specific name were to be given, Meek's name papyraceus should certainly be arlopted." c With this opinion I differ. If it were possible to credit the species to Meek, it would be a pleasure to do so, for there is no paleontologist for whom I entertain a higher admiration, but no nomenclator, I am sure, would think of crediting the species to Meek under our present rules of nomenclature. The only writers who have used the term Liorhyn-

$a$ Rept. U. S. Geol. Expl. 40th Par., vol. 4, 1877, p. 80.

6 Am. Jour. Sci., 3d ser., vol. 11, 1876, p. 479.

cAnn. Kept. (ieol. Surv. Arkansas for 1892, vol. 5, 1900, p. 346. 
chus papyraceus in print are King and Williams, who mention it in a most casual way, as indicated above. The citation in either case can hardly be considered anything but a nomen nudum, with a barely possible reversion to the description and figures of Meek. In view of the facts that the species would, with little question, be credited to my authorship, no matter what name is used here, that the identity of the Arkansas and White Pine fossils, though probable, is not certain, and that the specimens from Nevada are crushed and imperfect, it seems to be for the best interest of science to introduce an entirely new name and base it upon the excellent material from the Moorefield shale. If the Nevada form proves distinct, it will then be possible to employ the name which was first associated with it, Liorhynchus papyraceum.

Horizon and locality.-Moorefield shale, Batesville quadrangle, Spring Creek (stations 1237R, 1248A1, 1248A2, 1248A5, 1248A6, 1248R, 1248R4, 1248R5, 1248Rx(?), 1248T, 1248Y, 2048, 2049, 2049a(?), 2049c, 2049e, 2049f, 2053); Moorefield (stations 2051a, 2051b); Marshall quadrangle, Marshall (stations 7038, 7038c).

\section{LIORHYNCHUS CARBONIFERUM VAr. POLYPLEURUM n. var.}

Plate VII, figures 7-12.

1909. Liorhynchus aff. laura. Girty, U. S. Geol. Survey, Bull. 377, p. 27, pl. 2, figs. 13-15.

Caney shale: Antlers and Tishomingo quadrangles, Oklahoma.

In several collections there occur, associated with typical Liorhynchus carboniferum, specimens which are distinguished by having the sides as well as the median portions ornamented by costæ, and these it has seemed expedient to discriminate as a distinct variety. This is, however, the only difference that has been noted, and there seems to be a perfect gradation between forms having lateral costæ and those in which the costæ are confined to the mesial portion, the series being in fact completed by shells which seem to be without costæ anywhere on the surface. . In the matter of intergradation we find shells which have distinct mesial costæ, but only one or two lateral ones; shells which have distinct mesial, but many indistinct lateral ones, so indistinct in some cases that one can not be quite sure that costæ are really present at all; and, lastly, shells-a few of them-that have lateral costæ over the immature portions, but none upon the mature ones. In this connection the fact may be again noted that a much larger per cent of the young than of the mature specimens bear lateral costæ.

While specimens occur about which there might be disagreement, these shells with lateral costæ present fairly distinct characters and form a fairly well-marked group, which, it seems to me, would better 
be discriminated as a separate variety than merged with Liorhynchus carbonifirum.

There can be little question that this is the same form which in a report upon the fauma of the ('aney shale I compared with L. laura, while the form without lateral costre was compared with $L$. mesicostale. The poorly preserved and not very copious material obtained from the c'aney shale did not aflord data satislactorily to separate the Carboniferous from the Devonian forms, but the Spring ('reek material makes this discrimination desirable, at least in the case of $L$. carboniferum. The fossils representing the present form are far less abundant, and they cun not be compared in as detailed a manner with the IIamilton material at hand representing L. multicosta (=L. laura). A very close resemblance exists between certain specimens, but as I am convinced that the form under discussion is only variety of L. carboniferum, the present treatment has been adopted. Taken by and large, such material as I have seen of $L$. multicosta has plications which are finer, more numerous, more unequal and bifurcating, and more persistent.

IIorizon and 7ocality.-Moorefield shale, Batesville quadrangle, Spring (reek (stations 1248A1, 1248A2, 1248A5, 1248R5, 1248Y, 2048, 2049) Moorefield (station 2051a); Marshall quadrangle, Marshall (stations 7038, 7038c.)

\section{Genus CAMAROTGCHIA Hall and Clarke.}

\section{Camarotechia purduei Girty.}

Plate $\mathrm{V}$, figure 5 .

1910. Camarotochia purduci. Girty, New York Acad. Sci., Annals, vol. 20, No. 3, s pt. 2, p. 219.

Bawal Fayetteville shale: Fayetteville quadrangle, Arkansas.

The majority of the specimens from the Moorefield shale at Marshall are like $C$. purduei var. laxa, but a relatively few are distinguished by having deeper and more angular plications and therefore being in very close agreement with $C$. purduei itself. These intergrade with the variety laxa and no sharp line can be drawn between them.

IIorizon and locality.-Moorefield shale, Batesville quadrangle, Spring Creek (station 2049b).

\section{Camarotechia purduei var. agrestis n. var.}

Plate V, figures 1-4.

The fossils subsumed under this title are abundant in some of the beds of the lower Moorefield shale on Spring Creek and present much variation in all their characters. They show the usual variability in proportion of length and width, some specimens being narrow and 
others broad. The outline also varies. The costæ in general character are such as are usually found in this genus-rather strong and angular and persistent, but they vary in the two characters first named, at all events. The number and arrangement also varies widely, but in general it seems to be true that their size varies inversely to their number, so that when the number is relatively few the size is large, and vice versa. As a rule there are four or five plications on the fold and three or four in the sinus, but seldom less, while specimens having six or even seven are more or less frequent. The lateral plications number usually five or six, rarely seven, on the dorsal valve and six or seven on the ventral; rarely four on the dorsal and five on the ventral. In some instances the plications on the fold and sinus are distinctly larger than the lateral ones, but usually they are of the same size. The fold and sinus are moderately strong and as rule well defined by reason of their sides being broader than the sieles of the other plications, but in some cases there are plications on the sides of the fold and sinus, so that, occasionally it is impossible to determine exactly their limits. This median zone seems to be the locus for the introduction of new costæ of a different order or system from the others, than which they are almost always smaller. That these costæ occur on the sides of the fold and sinus has already been mentioned, but they are also found on the fold and sinus, being distinguished from the others, of course, by their small size. Nor are they always developed symmetrically; more often than not a supernumerary plication occurs on one side and not on the other.

These shells resemble those from the basal Fayetteville, which I described as Camarotochia purduei, but differ generally in the following particulars. They are larger and with more numerous costæ. The arrangement of the costæ is more variable. While in $C$. purduei there are three or four plications on the fold and rarely five, in this variety there are four or five or even more and very rarely three. The lateral plications are usually six instead of five, and rarely if ever so few as sometimes found in C. purduei. While this statement is true in the main it is not wholly true of individuals, and the two varieties appear to be connected by intermediate forms to some extent.

Horizon and locality.-Moorefield shale, Batesville quadrangle, Spring Creek (stations 1248A12, 1248R, 1248R4, 1248T, 2048, 2049b).

Camarotechia pURduei var. laXa n. var.

Plate V, figures 6-11.

This form is represented in but one of the collections from the Moorefield shale, but is there very abundant. In a general way it resembles the species found at about the same horizon at Batesville, but presents some constant differences. The size is as a rule smaller 
and the plications fainter and lexs numerous. The usual number on the fold is four, but three are almost as commonly found there. Only five specimens out of a large number show five. The usual number of lateral plications on a dorsal valve is six, the final one or two being faint, but in some cases there are only five, and in a few others seven or eight. Compared with C. purduei var. agrestis the difference in the size and strength of the plications is less important and less marked than the difference and constancy in the number of mesial costre, yet it seems unwise to include them in the same variety. In number and arrangement of plications this form more nearly agrees with $C$. purduei itself, but the plications, though sometimes angular, are as a rule much lower and more evanescent. They are thus more nearly in agreement with the variety laxa, from which most of the specimens differ only in being a little larger. Some doubtful specimens have broadly angular plications and a strongly elevated and produced fold.

Iforizon and locatity.-Moorefield shale, Marshall quadrangle, Marshall (station 7039).

\section{Subgenus MOOREFIELDELLA n. subgen.}

This name is introduced for the peculiar rhynchonelloid type of which $R$. eurekensis is a representative. The peculiarity of the group (omsists rather in the external expression than in the internal structure, for so far as known that form agrees strueturally with Liorhynchus and Camarotochia. The ventral valve has a pair of dental plates and the dorsal a well-developed median septum which unites with a large hinge plate at the posterior end. The hinge plate bears a median groove which was probably continued on to the upper edge of the septum so as to form an incipient spondylium. Two rather large muscle scars oceupy a median position in the dorsal valve, being divided by the septum.

As just remarked, this structure does not differ essentially from that of Liorthynchus or Camarotachia, but the external expression of the shell, determined by the low, ill-defined fold and sinus and the very numerous fine rounded costax, makes this form rather unique. At first one would say that Moorefieldella had much more the expression of Camarotochia than of Liorhynchus, ret it almost intergrades with Liorhynchus carboniferum, with which it occurs in association. The latter species passes into the variety polypleurum, in which the lateral costre are not obsolete, and both types show considerable variation in point of the costæ, some having finer and more numerous ribs than others. This is true also of $M$. eurekensis, so that the coarsely plicated examples of the latter tend to pass into the finely plicated Liorhynchus with lateral costæ. One would almost be jus- 
tified in regarding this as a diverse modification of the same type of shell.

Moorefieldella eurekensis seldom has the pentagonal outline and pyramidal shape found in the most characteristic Camarotochia. It is furthermore distinguished by having a relatively very large number of fine rounded ribs instead of a small number of coarse angular ones, as in typical Camarotochia. The fold and sinus are also less differentiated, that structure in Camarotochia being usually high and angular and specialized by having the mesial costæ separated from the lateral ones by wider intervals than those which divide the other costæ from one another. That is to say, the sides of the fold are unplicated. In Moorefieldella eurekensis, however, the plications are, generally speaking, uniform and not differentiated by the low rounded fold and sinus. Of course, these differences only exist in a general way, the most striking being the large number and fineness of the ribs, but it is believed that this group is distinguished by the same kind of differences and by as important ones as other groups which have been recognized among the Rhynchonellidæ, and while of subordinate value it will serve a useful purpose in designating a peculiar type of expression in a very variable family.

Type.-Moorefieldella eurekensis.

Moorefieldella eUrekensis Walcott.

Plate V, figures 12-17.

1884. Rhynchonella Eurekensis. Walcott, U. S. Geol. Survey, Mon. 8, p. 223, pl.18, figs. 8-8c.

Lower Carboniferous: Eureka district, Nevada.

Shell rather small, seldom attaining a length of $20 \mathrm{~mm}$. Shape generally ovate, seldom subpentagonal or subtriangular. Proportions very variable, rarely transverse, usually elongate, in some cases very elongate. Convexity ranging from rather low to moderately high. Dorsal valve more convex than the ventral, sometimes rather gibbous in the umbonal region. Ventral beak produced and not strongly incurved. Fold and sinus usually rather low and undefined, but occasionally high and sometimes well defined. This feature is not developed until the shell has attained a relatively large size, and small specimens present a superficial resemblance to species of Eumetria. The fold and sinus vary considerably in width proportional to that of the entire shell. The costæ are numerous, numbering fifty or more; they are fine, rounded, not strongly elevated, and very even and regular. Usually about ten occupy the fold and about twenty the sides, but these numbers vary greatly, depending on the relative size (for in this respect considerable variation is shown), the width of the shell as a whole, and the relative widths of the fold and 
sinus. The minimum on the fold, so far as observed, is eight, and the maximum fourteen or sixteen. The costre become finer and fainter laterally, those toward the hinge being often more or less undeveloped. The sides of the fold and sinus are often plicated like the rest of the surface, so that no definite boundary can be determined.

The internal structures are essentially identical with those of Liorhynchus, so far as determined, but the muscular imprints are rarely shown. The ventral valve has two dental plates rather far apart and more or less consolidated with the shell walls. The inner surface of the shell between them is finely marked by cross striæ. In the dorsal valve there is a large hinge plate with a median groove and cremulated sockets, joined to a rather long high septum. The muscular imprints are poorly preserved in the dorsal valve also, but seem to consist of a pair of scars, less elongated than those of Liorhynchus carbonifirum, but similarly placed near the middle of the valve and separated from one another by the septum.

Young specimens of this form occur in the same bed where, as already mentioned, young shells of Liorhynchus carboniferum are abundiant. They show the same peculiarities of preservation, having a black, shiny coating as if possessing a phosphatic layer, which also shows fine regular markings suggestive of punctation. The muscle scars also are similar to those of young Liorhynchus carboniferum, and the coarsely ribbed shell of one comes near to graduating into the more finely ribbed shell of the other.

This form, which is rather abunclant in the Moorefield shale, is, without much loubt, the same which C. D. Walcott described from the Eureka district of Nevada. It was also so identified by H. S. Williams. About the only difference at present determinable is that the shells from Arkansas are somewhat larger. As pointed out by Walcott, one of the typical specimens was slightly crushed. The quadrate outline which his figure shows and by which it contrasts strongly with those given here of Arkansas specimens is due to his specimens having been tilted downward when drawn, so that the front end appears to project more than when the specimen lies with the plane of juncture of the valves horizontal.

Horizon and locality.-Moorefield shale, Batesville quadrangle, Spring Creek (stations 1237R, 1248A1, 1248A2, 1248A5, 1248As, 1248R, 1248R4, 1248R5, 1248T, 1248Y, 2048, 2049, 2049b).

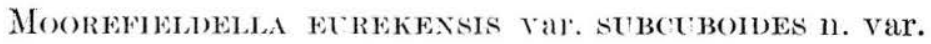

Plate I, figure is.

While the sperimens referred to Moorefieldella eurekensis show a considerable variation in the size of the costre, one among them represents so marked a departure as to demand recognition as a definite 
variety. It has a broadly subovate or slightly pentagonal outline with moderate convexity. The fold has a broad squarish shape and carries nine plications, which are a little coarser than those on the sides. The lateral ribs number nine or ten. This specimen presents a curious resemblance to the characteristic Devonian Hypothyris cuboides.

Horizon and locality.-Moorefield shale, Batesville quadrangle, Spring Creek (stations 1248R5, 1248Y).

\section{TEREBRATULIDA.}

Genus HARTTINA Fall and Clarke.

Harttina bRevilobata Swallow.

Plate II, figure 12.

1863. Terebratula brevilobata. Swallow, St. Louis Acad. Sci., Trans., vol. 2, p. 84. Archimedes limestone: Ste. Genevieve County, Mo.

The two forms, which, in describing the fauna of the lower Fayetteville shale, are discriminated under the titles Harttina brevilobata and H. brevilobata var. marginalis, occur also in the "Spring Creek limestone." Though found in but one of the collections, they are fairly abundant, many of the specimens, however, being imperfect. In the present material these two forms are perhaps not quite so sharply defined as in the Fayetteville collections, but at the same time it is possible to discriminate them.

The shells referred to $H$. brevilobata are all of about the same size as the Fayetteville examples, or perhaps a little larger, but they are distinctly smaller than the originals described by Swallow. They have a broadly ovate or subpentagonal shape and are rather highly convex. The ventral valve bears a somewhat narrow deep sinus, which can be traced back about two-thirds of the distance from the front to the beak, or less. Toward the front the dorsal valve develops two rather broad shallow sulci, more abrupt on the median side, which leave between them a narrow well-defined fold, corresponding to the ventral sinus.

Some young shells which perhaps might be mistaken for the form from the lower Fayetteville shale which I identified as $H$. indianensis var. exporrecta, have been identified as this species because they show more or less definite traces of the characteristic lobation.

Horizon and locality.-Moorefield shale, Batesville quadrangle, Spring Creek (station 1248R4).

$46447^{\circ}$-Bull. $439-11 \longrightarrow 5$ 


\section{HartTina brevilobata var. marginalis Girty.}

Plate II, figure 13.

1910. Ifarttina brrvilobata var. marginalis. Girt!. New York Acad. Sci., Annals., vol. 20, No. 3 , pt. 2 , p. 219.

Iasal Fayetteville shale: Fayetteville quadrangle, Arkansas.

These shells from the Moorefield shale seem to be specifically identical with those from the basal Fayetteville, on which this variety was founded. The largest has a length of $12 \mathrm{~mm}$. The shape is rather elongate-ovate, and the convexity moderate. The configuration as to fold and sinus resembles that of $H$. brevilobata, but the plications are fainter and more marginal. In the dorsal valve they are nearly or quite obsolete, so that some specimens appear to have merely a not very strong sinus in the ventral valve and an indistinct flattening in the dorsal. As might be expected, such examples are not readily discriminated from $I I$. brevilobata, but typically this form is narrower, less inflated, and less distinctly and more marginally plicated than the associated shells identified with Swallow's species.

IIorizon and locality.-Moorefield shale, Batesville quadrangle, Spring Creek (station 124SR4).

\section{SPIRIFERID $A$.}

\section{Genus SPIRIFER Sowerby.}

SPIRIFER ARKANSANL'S 11 sp.

Plate 1.11 f figures 2, 3, 4 .

Shell larece, attaining a length of $50 \mathrm{~mm}$. Rather long for the width, but in all cases the width is greater than the length. Hinge line usually shorter than the greatest width, which then occurs just below, but sometimes the cardinal angles are quadrate and sometimes slightly extended. The convexity of both valves is moderate. The ventral area is sharply defined but not very high, and it has a wide foramen. The boak of the ventral valve is rather strongly. incurved over the area. The fold and sinus are strong but undefined except toward the umbones. The costæ are usually broad and flat with narrow shallow striæ between, and they tend to bifurcate on all portions of the surface. The original costæ especially are broad and flat, while after bifurcation the ribs are apt to be, for a distance at least, narrow and well rounded. Owing to the originally rather faint development of the costre, especially toward the sides, and to the exfoliation which all specimens have undergone, it is difficult to makt an exact count of the ribs, but usually there are nine or ten on a side, in some cases as many as thirteen. Toward the front of mature 
shells, where many of the costæ have bifurcated, the number is of course sometimes considerably greater. In the uppen part of the sinus there are usually three ribs besides the two others, one on each side, which form its boundary. Each of these may bifurcate toward the front, while the bounding rib may give off a branch on the inner side.

The superficies is covered with fine regular radiating liræ, which, though often removed by exfoliation, have been observed on many specimens. Probably there are no coordinate transverse markings, but on a few specimens more or less irregular, relatively coarse, lamellose growth lines have been noted.

In some cases, especially in young stages as defined by growth lines, the shape is much like that of $S$. rostellatus or $S$. tenuimarginatus, while in others it is more like $S$. keokuk or $S$. logani. Specimens in which the original costæ persist broad, flat, and ill-defined to the end, present a different appearance from those in which the costæ have bifurcated and are numerous, relatively fine, and fairly high. That these are not really discriminable varieties, however, is shown by an occasional instance in which one valve has the ribs divided, while on the corresponding valve of the same specimen they remain simple. Occasionally also the bifurcation or trifurcation, which is sometimes though rarely found, give the liræ a fasciculated appearance more suggestive of $S$. cameratus.

Some specimens simulate $S$. subcardiiformis, but the presence of dental plates and of fine radial liræ show them to belong to an altogether different group. Normal mature specimens of this species are easily distinguished from Spirifer keokuk and clearly belong to a different species, but some aberrant examples, when not fully grown, must have resembled $S$. keokuk considerably. Even these, however, have the costæ less angular and more frequently bifurcating and the fold and sinus lower and less well defined.

Much more close is the relationship with Spirifer logani, also of the Keokuk period. S. logani is a broader form and has also a broader sinus and fold. The beak of the ventral valve is smaller, broader, less prominent and less incurved. The costæ maintain by bifurcation a nearly uniform size, much smaller-than the unbifurcated costæ often so persistent on the surface of $S$. arkansanus.

This species shows a resemblance as strong as it is remarkable to S. nikitini, which Tschernyschew has recently described from the "Upper Carboniferous" of Russia. ${ }^{a}$

Horizon and locality.-Moorefield shale, Batesville quadrangle, Spring Creek (stations 1248A1, 1248A2, 1248R, 1248R4, 1248Rx, 2048, 2049a, 2049c, 2049f). 


\section{SPIRIFER MOOREFIELdant's 1 . sp.}

Plate VIII, tigure 1.

This species is rare in the "Spring Creek limestone," the collections having furnished only three specimens, all of which are ventral valves. The size is small and the convexity low. The width attained was $30 \mathrm{~mm}$., or perhaps more. The shape is triangular and very transverse, with the greatest dimension at the hinge. The beak is small, not very prominent, and has the end curved inward over a low concave area. The foramen is narrower than high. The sinus is shallow, broad, and not very well defined. It appears at first sight to be simple, but is really occupied by two or three extremely obscure coste. The lateral costæ, which number eight or nine, are inclined to be rather faint, and a few of them appear to bifurcate toward the front in one specimen.

The whole surface is marked by closely arranged, regular, equal, lamellose, concentric striæ. No unequivocal evidence exists indicating that there were radial markings surmounting the costæ.

Spirifer moorefieldanus is related to $S$. imbrex of the Burlington limestone, but is distinguished by its coarser and less numerous lateral plications and by the obscure and evanescent nature of those occupying the sinus.

IIorizon and locality.-Moorefield shale, Batesville quadrangle, Spring Creek (stations 1248R4, 2049a).

\section{SPIRIFER INCREBESCENS IIall.}

1858. Spirifar imerebesens. Hall, Geol. Survey lowa, Rept., vol. 1, pt. 2, p. 706 ' pl. 27 , figs. $6 \mathrm{a}-\mathrm{i}$.

Kaskaskia limestone: Kaskaskia and ('hester, Ill.

1858. Spirifer keoluk var. Hall, Geol. Survey Iowa, Rept., vol. 1, pt. 2, 1). 676, pl. 24, figs. $4 \mathrm{a}$ ?, 4b, 4c, 4d?.

St. Louis limestone: Mouth of Lizard ('reek, Webster County, Iowa.

1883. Spirifera increbescens. Hall, New York State Geologist, Rept. for 1882, pl. (30) 55, figs. 27-30, pl. (31) 56, figs. 1-3.

('hester limestone: Illinois.

1888. Spirifer increbescens. Herrick, Scri. Lab. Denison Univ., Bull,, vol. 4, pl. 11, figs. $14,23$.

('hester limestone: Ohio; also from limestone fragments in Pennsyivanian conglomerate, Licking County, Ohio.

1893. spirifer increbescens. Hall and Clarke, Geol. Survey New York, Pal., vol. 8, pt. 2, pp. 27, 39. (Advance distribution in fascicles.)

1894. Spirifer increbescens. Hall and Clarke, New York State Geologist, Thirteenth Ann. Rept., for 1893, vol. 2, pl. 27, figs. 8-11. (Also published separately as Introduction to 'Brachiopoda: hand-book for students.')

('hester limestone: Chester, Ill.

1895). Spirifera increbescens. Keyes, Missouri Geol. Survey, Rept., vol. 5, p. 82. (Date of imprint, 1895.)

Kaskaskia limestone: st. Mary, Mo. 
1895. Spirifer increbescens. Hall and Clarke, Geol. Survey New York, Pal., vol. 8, pt. 2 , pp. 27,39 , pl. 30 , figs. 27-30, pl. 31, figs. 1-3.

Chester limestone: Chester, Ill.

1897. Spirifer Keokuk. Weller, New York Acad. Sci., Trans., vol. 16, p. 257, pl. 19, figs. 10-12. (Date of volume, 1898.)

Batesville sandstone: Batesville, Ark.

Of this species the collection contains only a single example, a small fragmentary dorsal valve. The length of this specimen could not have been less than $13 \mathrm{~mm}$. and may have been more. The fold is narrow, high, and defined by deep sulci. It is surmounted by four strong ribs, while the sides of the valve bear nine others of similar character. In so far as the characters are shown by this specimen it appears to be the same form which occurs in the basal Fayetteville shale and which I have identified in the same manner.

Horizon and locality.--Moorefield shale, Batesville quadrangle, Spring Creek (station 1248R4).

\section{Genus RETICULARIA McCoy.}

\section{Reticularia setigera Hall.}

Plate VIII, figure 6 .

1858. Spirifer setigerus. Hall, Geol. Survey Iowa, Rept., vol. 1, pt. 2, p. 705, pl. 27, figs. $4 \mathrm{a}, \mathrm{b}$.

Kaskaskia limestone: Kaskaskia and Chester, Ill.

1877. Spirifera setigera. Hall and Whitfield, U. S. Geol. Expl. 40th Par., Rept., vol. 4, p. 270 , pl. 5, figs. 17, 18.

Lower Carboniferous limestone: North of Snowistorm Hill, Dry Canyon, Oquirrh Mountains, Utah.

1883. Reticularia setigera. Waagen, India Geol. Survey, Mem.; Pal. Indica, ser. 13, vol. 1, p. 542.

1883. Spirifera setigera. Hall, New York State Geologist, Rept. for 1882, pl. (36) 61, figs. 26, 27.

Chester limestone: Chester, Ill.

1893. Spirifer setigerus. Hall and Clarke, Geol. Survey New York, Pal., vol. 8, pt. 2, pp. 21, 37. (Advance distribution in fascicles.)

1895. Spirifer setigerus. Hall and Clarke, Geol. Survey New York, Pal., vol. 8, pt. 2, pl. 36, figs. 26, 27. (Date of imprint, 1894.)

Chester limestone: Chester, Ill.

1895. Spirifera setigera. Keyes, Missouri Geol. Survey, Rept., vol. 5, p. 83. (Date of imprint, 1894.)

Kaskaskia limestone: St. Mary, Mo.

1906. Reticularia setigerus. Beede, Dept. Geology and Nat. Res. Indiana, Thirtieth Ann. Rept., p. 1318, pl. 21, figs. 1, 1a.

Salem limestone: Lanesville and Bedford, Ind.

This species is fairly abundant in several collections from the "Spring Creek limestone," but the fossils are imperfect and poorly preserved. It is probably safe to identify this form with Hall's $R$. setigera, though it shows some differences from the typical specimen 
figured by him. It is somewhat smaller and with a more regularly elliptical outline. Such differences are often due to age and individual peculiarities and at this time they are not thought to warrant the discrimination of the Moorefield shells. These have also only a slightly developed fold and sinus with a dorsal valve considerably less convex than the ventral. It is true, however, that the clorsal valve is very imperlectly represented amongst the material studied. The specimens under consideration show considerable variation in the proportions of length and width, some examples being strongly transverse and others more nearly circular in outline.

Morizon and locality.-Moorefield shale, Batesville quadrangle, Spring ('reek (stations 2048, 2049a, 2049b, 2049c).

\title{
Genus MARTINIA McCoy.
}

\section{MaRTINIA gIABRA Martin?}

\author{
Plate IX, figures 9, 10, 11.
}

1809. Anomites gluber Martin. Petrifacta Terbiensia, pl. 4s, figs, 9, 10.

Carboniferous limestone: ('helmerton, Tideswell, England.

1858. Spirifera glabra. 1)avidson, Pal. Sox.; Mon. British Fossil Brach., pt. 5, Carb. Brach., p. 59, pl. 11, figs. 1-9; pl. 12, figs. 1-5, 11, 12. (This publication gives a synonymy of European (citations.)

Carboniferous limestone: England, Scotland, Ireland, Belgium, France, Russia, America, etc.

1863. Spirifere glabru. Davidson, Geol. Soc. Iond., Quart. Jour., vol. 19, p. 170, pl. 9, figs. 9, 10.

Tower (arboniferous limestone: East River of Pictou, Mabou, Cape Breton, Windsor, Brookfeld, Merigomish, etc., Nova Scotia.

1868. Spirifere glubro. D)awsen, Aratian (icology, 1). 291, fig. 89.

('arboniferous limestone: Fast River of Pictou, Kabou, Cape Breton, Windsor, lirookforl, Merigonish, ete., Novat Scotia.

The shells subsumed under this title are rather abundant at certain horizons in the lower Moorefield shale, but for the most part their preservation is unsatislactory. They have a somewhat quadrate shape with the width always greater than the length. This dimension seems to be greatest at the cardinal line or slightly in front. A width of $40 \mathrm{~mm}$. is about the maximum observed.

Most of the specimens examined are ventral valves. They are rather highly convex, especially in the umbonal region, and the beak is much elevated and strongly incurved over a rather low area. The foramen is broader than high. There is a listinct narrow sulcus passing forward down the middle of the valve, which, toward the front, develops a broal undefined sinus.

Of the dorsal valve our imperfect material does not permit me to give a description. It probably had a triangular or semicircular shape, rather low conrexity, and a moderately high though undefined mesial fold. 
The surface appears to be nearly or quite smooth. Many specimens, however, show fairly regular, numerous, closely arranged incremental striæ on exfoliated surfaces, such as almost all the specimens expose.

This form is not readily distinguished from a number of quite different types with which it is associated, such as Composita subquadrata var. lateralis, Reticularia setigera, and even such specimens of Liorhynchus carboniferum as have the plications obsolescent. Of course, the configuration should distinguish it immediately from the Liorhynchus and the Composita, and the sculpture from the Reticularia, but most of the specimens are so imperfect that the configuration is obscured and so exfoliated that the sculpture is largely obliterated. They are liable to be compressed, in which condition one often can not determine whether there was an area or not, and even when not compressed are separable only by much labor from the hard, tenacious rock that hides the configuration. Furthermore, the shell is much thickened over the umbonal portion but is thin laterally, so that the margins are apt to be broken away or crushed in such manner as to obscure the shape.

One can not even employ the internal structures to discriminate this from the other types, because these seem to show an almost unprecedented amount of variation. Indeed, some specimens seem to be without dental plates, as the case should be if they properly belong to Martinia, while others almost certainly possess them, and so apparently belong to the genus Martiniopsis. These fossils are not preserved so as to show the internal structures, and I could not afford to sacrifice much material in the investigation, for of course, to be of service, the specimens mutilated for the purpose must be so complete that there is little doubt as to their specific identity. I believe that the specimens upon which my observations were made do not belong to Reticularia, Composita, or Liorhynchus, and it seems that the greatest amount of, as well as the clearest, evidence points to the presence of dental plates. Consequently I should, perhaps, assign this form to Martiniopsis rather than to Martinia. Just here, however, another possibility intervenes. A few of the specimens appear to have plications. These are extremely indistinct and are not developed symmetrically; that is, they occur on one side of the shell and not on the other; but their presence may signify not a Martiniopsis but a Spirifer, one perhaps related to arkansanus, but with the plications almost obsolete.

It is clear that if three genera or subgenera are present among these specimens it is impossible to separate them in their present condition. On the other hand, if all belong together, it is quite difficult to decide to what genus they would best be referred, Martinia, Martiniopsis, or Spirifer. If a Martinia, this species appears to be very similar to the English Martinia glabra, though I have not had specimens of the latter with which to compare them. Since my 
cridence is not very sure and is even conflicting, it has seemed best on the whole to defer a decision on the generic and specific relationships of these specimens, and they have therefore been referred provisionally to the foreign species named above. It is desirable, however, that this reference be revised as soon as it can be done with sufficiently complete material to warrant a definite result.

IIorizon and Incality.--Noorefield shale, Batesville quadrangle, Spring Creek (stations 1248R, 1248R4, 1248Rx, 1248T(?), 1248V, 2048, 2049a, 2053).

\section{Martinia sp.}

Plate IX, figure 8 .

1909. Martiniu sp. Girty, U. S. Geol. Survey, Bull. 377, p. 29, pl. 2, fig. 9. ('aney shale: $\Lambda$ tokil and Tishomingo quadrangles, Oklahoma.

Seven or eight specimens in the Moorefield collection can probably be referred to the genus Martinia, but they appear to belong to a species different from that of the large shell provisionally identified as Martinia glabra. They are small and of a subpentagonal outline. The width and length are about equal, the wilth being usually somewhat the greater. The cardinal angles are more or less rounded, but the hinge line is nearly as long as the greatest width. The dorsal valve is rather flat, but the ventral is highly convex, with a narrow median sulcus. On the interior the ventral valve seems to be without dental plates, but the umbonal region is much thickened. The interior of the dorsal valve is not definitely known. The surface of a dorsal valve referred to this species and preserved as a mold of the exterior, appears to have been marked by fine irregular concentric strix and to have been covered with minute spines more or less arranged in concentric rows.

The configuration of these shells is clearly spiriferoid, so that their generic relations are probably with Martinia, Reticularia, or Ambocxlia. Though thickly covered with spines the surface has not the characters found in Reticularia and Squamularia, while the internal plates of the former genus are also lacking. A small dorsal valve provisionally referred here has appearances which suggest the internal strustures of Ambocalia, and possibly the entire group may belong to that genus, with which the shape, the sculpture, and the planiconvex configuration are in keeping. The size, however, is excessive for Amboccetia, all the known species of which are small. On the whole, it seems more probable that they belong to Martinia rather than to Ambocolia; at any rate, they are distinct from Ambocolia lævicula(?). Their high convexity, uniform size, and the apical callosity in the ventral valve inclicate that they are mature shells. If so, the small size and different shape indicate that they are also distinct from $M$. 
glabra. It is not impossible, however, that they are young examples of that species. Under the title Martinia sp. I have described and figured a specimen from the Caney shale of Oklahoma which has the same size and configuration as those from the Moorefield shale, and it is believed that all belong to the same species. In their present condition, at all events, it is impossible to tell them apart.

Horizon and locality.-Moorefield shale, Batesville quadrangle, Spring Creek (stations 1248A2, 1248R5, 2048, 2049c), Moorefield (station 2051a).

Genus AMBOccilia Hall.

Amboccelia levicula Rowley?.

Plate VIII, figures 7, 8, 9.

1900. Ambocelia levicula. Rowley, Am. Geologist, vol. 25, no. 5, p. 262, pl. 5, figs. 12-14.

Lower Burlington limestone: [Louisiana?] Missouri.

Shell small, a length of $5 \frac{1}{2} \mathrm{~mm}$. being about the maximum observed. Length usually, perhaps always, slightly less than the width. Shape variable. The cardinal angles are rounded but the outline is more abruptly curved at these points than elsewhere. Generally speaking, the outline is subcircular to subquadrate, but in some specimens the curving sides contract toward the front and in a few they diverge. The dorsal valve is gently convex and the ventral valve strongly so, though it is proportionally much lower than in some members of the genus. Our specimens are internal molds. The umbonal region of the ventral valve does not seem to have been much thickened. The beak therefore appears to have been rather strongly depressed and not greatly elevated. Both valves bear a median sulcus which varies in strength in different specimens.

In the dorsal valve there are two very elongated muscle scars, situated medianly, one on either side of the sulcus. Farther toward the umbo and somewhat closer together is a second pair of small scars. Traces of small crural plates can be observed in some specimens.

The scars of the ventral valve are not so distinct nor so differentiated as those of the dorsal. There are evidently two elongated areas of muscular attachment in the umbonal region of this valve, considerably depressed and separated by a low ridge, but not usually with any very distinct boundaries. Each of these grooves terminates below in an oval scar, and they may merely mark the path of progression of muscular loci, but they show interruption as if differentiated into another pair, and even possibly a third pair, of distinct areas. Suggestions of dental plates and even of a median septum are found in this valve also, but possibly they are misleading.

As regards its generic position this can hardly be called a normal Amboccelia. The ventral valve is not as elevated as usual, and the 
dorsal valve is not as planate as in the most characteristic species, but the internal features are perhaps more noteworthy than the configuration. I mean the absence or imperfect development of crural plates and the character of the muscle scars, not close together and anterior as in typical Ambocalia. It may be thought that these peculiarities are due to the fact that my observations are made on young shells, the mature ones being the form here cited under Martinia. sp. It is true that a greneral resemblance exists between the two, but specimens intermediate in size between the smaller and larger forms seem to be lacking; and, furthermore, that referred to Ambocolia has a simus in the dorsal valve which appears not to exist in the Martinia.

Specifically this form seems to be extremely similar to Ambocolia levicula Rowley, though I have not had specimens of Rowley's species for comparison. The two forms are of somewhat different geologic ares and occur in association with very unlike faumas, and the probability would certainly appear to be that they are different species rather than the same. This genus, however, appears to adhere very closely to a type, and these Moorefield shells are so similar to Rowley's description and figures that I would be at a loss to name characters by which they could be discriminated unless it be that in the typical form the umbo of the ventral valve is fuller and its beak more recurved, so as to overhang the area. Of course, if $A$. levicula is a typical $A m$ bocolita the internal characters of the present form would distinguish it.

Some other and little-known species also should be considered in this connection, since they may prove to be the same form which Professor Rowley has described. I refer to Ambocolia minuta and to the shell which Winchell named Spirigera bitoba, but which I am fairly sure is really a spiriferoid resembling A. levicula.

The specimens from the Moorefield shale come chiefly from the bed which has furnished young specimens of Liorhynchus and Moorefieldeila. The Ambocolias occur as molels which have a similar black and lustrous surface with a similar appearance of punctate structure.

IIorizon and locality.-Moorefield shale, Batesville quadrangle, Spring ('reek (stations 1248A1, 1248A2, 1248A5).

\section{Genus SPIRIFERINA D'Orbigny.}

\section{Spiriferina subelliptich var. Fayettevillensis Girty?}

Plate VIII, figure 5 .

1910. Spiriferina subclliptica var. fayettevillensis. Girty, New York Acad. Sci, Annals, vol. 20 , no. 3 , pt. 2 , p. 221 .

Bassal Fayetteville shale: Fayetteville quadrangle, Arkansas.

This is a rare species in the Moorefield shale; only three specimens have come to hand, two dorsal and one ventral valve. The shape is transverse, triangular, broadest at the hinge or a little in front. The 
fold and sinus are small and distinctly larger and more prominent than the lateral plications. The latter number about seven on either side. They are rather fine and not very high nor sharp.

All the specimens are too deeply exfoliated to show the sculpture except the ventral valve, where, toward the umbonal region, the shell has retained traces of regular, concentric, imbricating lamellæ.

The dorsals, which do not retain any evidence of the original sculpture, seem to belong to the same species as the associated ventral so far as their characters are shown at all. They may, however, be a variety of $S$. spinosa, which all three shells suggest in configuration. The fold and sinus are, however, larger and higher in comparison with the lateral plications than is the case in $S$. spinosa, while the sculpture retained on the ventral valve shows that it at least belongs to an entirely different section of the genus.

These shells, assuming them all to be conspecific, also somewhat resemble $S$. transversa, especially in sculpture, but they are less transverse, the lateral costæ are less numerous, the fold and sinus are without a median plication, and the fold itself is more nearly the size of the lateral costæ. On the whole, they are nearest to S. subelliptica var. fayettevillensis, but even here some differences may be noted, the Moorefield form being larger and having the lateral plications less deep and strong.

Horizon and locality.-Moorefield shale, Batesville quadrangle, Spring Creek (stations 1248R4, 2049a).

\title{
ATHYRID A.
}

\section{Genus COMPOSITA Brown.}

\section{Composita subquadrata var. lateralis Girty.}

\author{
Plate IV, figure 10.
}

1910. Composita subquadrata var. lateralis. Girty, New York Acad. Sci., Annals, vol. 20 , no. 3 , pt. 2 , p. 222 .

Basal Fayetteville shale: Fayetteville quadrangle, Arkansas.

I have noted in the discussion of Martinia glabra that it is very difficult to decide whether some specimens really belong to Composita, Martinia, Liorhynchus, or Reticularia. It may be regarded as established that there are smooth examples of Liorhynchus carboniferum which simulate very closely the genus Composita, and also that the genus Composita occurs in the Moorefield fauna associated with them. Most specimens occur as dissociated valves embedded in matrix. In the case of ventral valves, the configuration of the area and foramen not being usually determinable, one has to rely on the fact that in Liorhynchus carboniferum the ventral beak is usually long and erect, and in Composita is shorter and more incurved, a means of discrimina- 
tion which does not afford very satisfactory results. In the case of dorsal valves the spiralia are of course never seen and the hinge plate which is differently formed in the two grenera is seldom brought to view. In Liorh!nchus, however, there is a well-developed septum which can usually be seen even in exfoliated specimens. In Composita the septum is nearly or quite undeveloped.

Using these data where others were not available, I have been able to identify some specimens positively and others more doubtfully with the genus Composita, at least so far as general form and expression are concerned.

Some of the compositas belong to a broad species, and these have much the shape of Martinia glabra. Where the configuration, especially of the apical portion of the ventral valve, can be made out, specimens can be referred with certainty to one genus or the other, but in many cases no such confidence is warranted.

One of the types present among the compositas, as already mentioned, is a large spreading species with rather broad deep fold and sinus. This form closely resembles that which I described in the fauna of the lower Fayetteville as Composita subquadrata var. lateralis. It does not seem to have quite the expression of that species, not having as abruptly rounded sides for one thing, but with the imperfect and limited material at hand it would be unwise to attempt to discriminate them. Such specimens oceur at $1248 \mathrm{R}$ and also probably at $1248 R 4$ and $2049 \mathrm{a}$. Somewhat less certain, though more abundant, is a form obtained at $2049 \mathrm{f}$ and $1248 \mathrm{~V}$. These fossils are smaller with a less well-developed fold and sinus. The shape is distinctly transverse and the expression is rather unusual. The configuration is not far from that which the specimens identified as $C$. subquadrata var. lateralis would have had at the same size and they have been provisionally identified with that species. It is possible, however, that some of them really belong to Martinia glabra(?).

Horizon and locality.-Moorefield shale, Batesville quadrangle, Spring Creek (stations 1248R, 1248R4, 1248V(?), 2048(?), 2049a, 2049 b (?), 2049f).

Composita madisonensis var. pusilla Girty.

Plate IV, figures 6,7 .

1899. Seminula madisonensis var. pusilla. Girty, U. S. Geol. Survey, Mon. 32, pt. 2, p. 564, pl. 71, figs. 3a, 3b.

Madison limestone: Yellowstone National Park.

Included here are two specimens which, from their configuration, it seems highly probable belong to a species of Composita. One is a ventral valve, a small narrow shell of an ovate shape with a deep narrow sinus, and it much resembles the form from Yellowstone Park 
which I described as Seminula madisohensis var. pusilla. The sinus is, however, deeper and traceable farther from the front border. This shell may also be reckoned merely a narrow example of the form from the basal Fayetteville shale which I have identified as $C$. subtilita. A few examples almost equally elongate have been included under that title, but such as I have examined have not the sinus quite so deep and narrow. The other specimen, which is a dorsal valve, has corresponding characters. The fold, however, shows toward the front a distinct indentation or median sulcus, and it may prove that this specimen represents a distinct species from the other.

IIorizon and locality.-Moorefield shale, Batesville quadrangle, Spring Creek (station 2049b).

\section{Composita aff. Humilis Girty. ${ }^{a}$}

Plate IV, figures $8,9$.

Among the specimens which appear to belong to the genus Composita are a few which resemble the western form described by me under the title Seminula humilis. They have a broadly ovate shape with fold and sinus almost undeveloped, and the larger specimens are tumid. The largest example is considerably larger than the typical shells from Yellowstone Park. It must have had a length of $22 \mathrm{~mm}$. or about $1 \frac{1}{2}$ that of the type.

These specimens may perhaps be regarded as belonging to the form from the basal Fayetteville shale which I identified as $C$. subquadrata or to the associated form here called C. subquadrata var. lateralis, but they are narrower than the latter and have a less distinct sinuation than specimens of the former of the same size.

A few small specimens from station 2048 have been provisionally placed here. They may really be representatives of Cliothyridina, but it is impossible to determine the fact.

The Compositas of the Moorefield fauna, it should be remarked, are so few and so imperfect that it is even less possible than usual to subdivide and identify them. The present classification is provisional.

IIorizon and locality.-Moorefield shale, Batesville quadrangle, Spring Creek (stations 1248A2, 2048).

Genus EUMETRIA Hall.

EUMETria Marcyi Shumard.

Plate VIII, figure 10.

1852. Terebratula serpentina? Owen (not de Koninck), Geol. Survey Wisconsin, Iowa, and Minnesota, Rept., pl. 3A, fig. 13. (See specimens in U. S. Nat. Mus.; Cat. Invert. Foss., 17955.)

Carboniferous: Skunk River, Iowa.

a Girty, G. H., Mon, U. S. Geol. Survey, vol. 32, pt. 2, 1899, p. 565, pl. 71, figs. 6a, 6b, 6c. 
1853. Terebratula marryi. Shumard, Marcy's Expl. Red River Louisiana, p. 203, pl. 1, figs. 4a, b. (As a Senate Ex. Doc.)

Carboniferous: Washington and (rawford counties, Ark.

18.5. Terebratula marcyi. Shumard, Marcy's Expl. Red River Louisiana, p. 177, pl. 1, figs, fa, 4h. (As a House Ex. Doc.)

('arboniferous: Washington and Crawford counties, Ark.

185s. Retzin Terncuilana. Hall, Albany Inst., Trans., vol. 4, p. 9.

St. louis limestone: Bloomington and Spergen Hill, Ind.

185̃s. Retzin remenilumu. Hall, Geol. Survey Iowa, Rept., vol. 1, pt. 2, p. 657, pl. 23, figs. la-d.

IV:arsaw limestone: Spergen Hill and 13lomington, Ind.

18is. Retzin rern. Hall, Geol. Survey Iowa, Rept., vol. 1, pt. 2, p. 70.1, pl. 27, fig. 3a. Kiskalskia limestone: ('hester, Ill.

1sis. Retzin rera var. costate. Hall, Geol. Survey lowa, Rept., vol. 1, pt. 2, p. 704, 1). 27 , figs. $3 \mathrm{~b}, 3 \mathrm{c}$.

Kaskaskia limestone: ('hester, Ill.

1\$6;:. Eumetria vera. Hall, New York State ('ab. Nat. Hist., Sixteenth Rept., p. 55, fig.. $L$ and 3 , and $p .59$.

18633. Eumetrin remeuili. Hall, New York State (ab. Nat. Hist., Sixteenth Rept., 1. 55, fig. 2 .

1852. Eumetriu Terneuilena. Whitfield, Am. Mfus. Nat. Hist., Bull., vol. 1, p. 50, pl.6, figs. $28-30$.

St. Jouis group: Spergen Hill, Paynters Hill, and Bloomington, Ind.; Alton, Ill.

1883. Eumetria remeniliena. IIall, Dept. Geology and Nat. Res. Indiana, Twelfth Rept., p. 335, p. 29, figs. $28-30$.

St. Jouis group: Spergen Hill, Lanesville, and Blownington, Ind.

1884. Retzin radialis. Walcott (non Phillips) (pars.), U. S. Geol. Survey, Mon. 8, p. 220, pl. 7, figs. 5a-5c, 5d, 5e (?).

Liper Devonian: Eureka district, Nevada.

Lower ('arboniferius: Eureka distriet, Nevadia; Little Belt Mountains, near ('Tendenin, Mont.

1889. Relzia Mareyi. Miller, North Am. Geology and Pal., p. 3665.

Kaskaskia group).

1893. Eumetria vera. IFall and ('larke, Geol. Survey New York, l'al., vol. 8, pt. 2, p. 117. (Advance distribution in fascicles.)

1893. Eumetria Verneniliana. Hall and Clarke, Geol. Survey New York, Pal., vol. 8, pt. 2, p. 11 $\bar{\imath}$, figs. 104, 105. (Advance distribution in fascicles.)

189-1. Eumetria Verneniliana. Hall and Clarke, State Geologist New York, Thirteenth Ann. Rept., pt. 2, pl. 37, figs, 1-4, 6, 10. (Also published separately as Introduction to Brachiopoda: handbook for students.)

St. Louis group: Spergen Hill, Ind.

1894. Eumetria vera var. costata. Hall and Clarke, idem, pl. 37, figs. 5, 11.

('hester limestone: Chester, Ill.; ('rittenden County, Ky.

1894. Eumetria vera. Hall and Clarke, idem, pl. 37, figs. 8, 12.

Chester limestone: Crittenden County, Ky.

1895. Retzia vera. Keyes, Missouri Geol. Survey, Rept., vol. 5, p. 95. (Date of imprint, 1894.)

Kaskaskia limestone: St. Mary, Mo.

1895. Retzia verneniliana. Keyes, Missouri (ieol. Survey, Rept., vol, 5, p. 95. (Date of imprint, 1894.)

St. Louis limestone: St. Louis, Mo.

1895. Eumetriu rera var. costata. Hall and (larke, Geol. Survey New York, Pal., vol. 8, pt. 2, pl. 51, figs. $27-33$.

Chester limestone: Crittenden County, Ky.; Chester, Ill. 
1895. Eumetria vera. Hall and Clarke, Geol. Survey New York, Pal., vol. 8, pt. 2, p. 117, pl. 51, figs. 36,37 .

Chester group: Crittenden County, Ky.

1895. Eumetria Verneuiliana. Hall and Clarke, Geol. Survey New York, Pal., vol. 8, pt. 2 , p. 117 , figs. 104 , 105, pl. 51, figs. 13-26, 34, 35; pl. 83, figs. $26,27$.

St. Louis group: Spergen Hill, Ind.; Greene County, Mo.

1897. Eumetria verneuilana. Weller, New York Acad. Sci., Trans., vol. 16, p. 259. (Date of volume, 1898.)

Batesville sandstone: Batesville, Ark.

1899. Eumetria verneuiliana. Girty, U. S. Geol. Survey, Mon. 32, pt. 2, p. 560, pl. 68, figs. 12a-12b.

Madison limestone: Yellowstone National Park.

1903. Eumetria marcyi? Girty, U. S. Geol. Survey, Prof. Paper 16, p. 303.

Ouray limestone: San Juan region, Colorado.

1904. Eumetria marcyi. Girty, U. S. Geol. Survey, Prof. Paper 21, p. 49, pl. 10, figs. 15-17.

Mississippian (Escabrosa limestone): Bisbee quadrangle, Arizona.

1906. Eumetria marceyi. Beede, Dept. Geology and Nat. Res. Indiana, Thirtieth Ann. Rept., 1905, p. 1319, pl. 22, figs. 28-30.

Salem limestone: Lanesville, Spergen Hill, Bedford, Bloomington, Paynters Hill, Harrodsburg, Stinesville, and Romona, Ind.

The Survey collections contain only five specimens of this species, all but the dorsal valve shown by my figure being fragmentary. The latter is larger and has fewer costæ than the specimen figured by Shumard, but not more so than some specimens from the lower Fayetteville shale of Washington County identified as Eumetria marcyi. Other specimens in the collection have perceptibly finer costre than that selected for illustration, and are more in accord with Shumard's figures.

While recognizing that there is a finely and a coarsely costate variety amongst this material, I doubt the utility or even the practicability of separating it and other suites into distinct groups of specimens.

IIorizon and locality.-Moorefield shale, Bateșille quadrangle, Spring Creek (stations 1248R4, 2049a( ?), 2049b).

\section{PELECYPODA.}

\section{SOLENOMYACID A.}

\section{Genus SOLENOMYA Lamarck.}

Solenomya? sp.

Plate XII, figure 7.

A single specimen, retaining both valves, but very imperfect as to outline and sculpture, is in the Survey collection. It is strongly transverse, with a width of about $55 \mathrm{~mm}$. and a height of about $22 \mathrm{~mm}$. The hinge line and lower border are nearly straight and parallel. The posterior outline is regularly curved. The anterior end seems 
to be rather narrow and prolonged some distance beyond the small beak. The convexity is moderately high without a distinct umbonal ridge. The sculpture seems to consist of rather strong concentric strix.

The generic and specific relations of this shell are both uncertain. The sculpture and general expression do not suggest an Allerisma. Were the umbonal ridge more distinct and the posterior extremity more truncated one might assign the shell to Sphenotus or Pleurophorus. In its shape it reminds one of Solenomyga parallela, but it is without the radiating markings of the group of shells included under Solenomya, to which that species belongs, and it also lacks the concentric plications and more compact shape of the other group represented by $S$. anadontoxies and $S$. soleniformis.

IIorizon and locality.-Moorefield shale, Batesville quadrangle, Spring Creek (station 1248T).

SOLENOPSIDA.

Genus SPHENOTUS Hall.

Sphenotus? Mesierianus Girty?

Plate XII, ligure 10.

1910. Sphenotus? mestcrianum. Girty, New York Arad. Sici., Annals, vol 20, No.3, pt. 2, p. 225 .

Basal Fayetteville shale: Fayetteville quadrangle, Arkansas.

Only one specimen has been referred to this species, and the reference is a provisional one. In a general way the configuration in the Moorefield specimen is much the same as in the type from near Fayetteville. The shape is not quite so transverse, however; the posterior extremity is more obliquely truncated and the umbonal ridge less distinctly developed.

IIorizon and locality.--Moorefield shale, Batesville quadrangle, Spring Creek (station 2049b).

\section{SpIIENotus? sp.}

Plate XII. figure 6.

This is a very transverse form, with straight and nearly parallel upper and lower margins. The posterior extremity is obliquely truncated and the strongly rounded anterior end projects slightly beyond the beak. The convexity is moderate and the umbonal ridge is indistinct. A constriction passes obliquely across the shell to the middle of the ventral border. The surface is marked by fine concentrice striæ.

The specimens included in this group are all very obscure and it was impossible to determine what many of the characters of each really 
were. Some of the fossils referred to here have a more strongly projecting anterior extremity than that shown by the figure and some are distinctly truncated, while that one is rounded behind.

In its generic relations this form (though there may be more than a single form present) is very uncertain, the most probable position being with Pleurophorus, Sphenotus, or Sanguinolites. Most of our American species of Sphenotus have one or more costæ between the umbonal ridge and the cardinal line, which appears not to be the case with the present form. Of the American species referred to Sanguinolites and Sphenotus, that which Weller figured as Sanguinolites sp. from very nearly the same locality, but from a higher horizon, is perhaps the most similar. The differences, which are obvious, may in part be due to the poor preservation of the specimens. Perhaps the most similar forms are, however, found under Pleurophorus, $P$. costatiformis, $P$. subcostatus, and $P$. taffi, all having a resemblance more or less close. In the basal Fayetteville Pleurophorus washingtonensis is the most similar. The present form is larger, less transverse, and without plications on the postumbonal slope. The relationship between this form and those which in the present fauna were designated Solenomya? sp. and Sphenotus meslerianus may prove to be closer than the generic references would indicate.

IIorizon and locality.-Moorefield shale, Batesville quadrangle, Spring Creek (stations 2048, 2049b).

\section{Genus SOLENOPSIS McCoy.}

\section{Solenopsis NITIDA Girty?}

Plate XII, figure 12 .

1910. Solenopsis nitida. Girty, New York Acad. Sci., Annals, vol. 20, No. 3, pt. 2, p. 223.

Basal Fayetteville shale: Fayetteville quadrangle, Arkansas.

Under this title are included an imperfect specimen from near Marshall and a still more imperfect specimen from near Batesville. In so far as the characters are shown at all these are not distinguishable from the specimens from Fayetteville on which this species was based, but better material may prove them to be distinct. The Marshall specimen has a thick shell marked by very fine incremental lines, and it appears not to taper quite so distinctly toward the posterior end as the typical example.

Horizon and locality.-Moorefield shale, Batesville quadrangle, Spring Creek (station 1248R4); Marshall quadrangle, Marshall (station 7039).

$46447^{\circ}-$ Bull. $439-11-6$ 


\title{
CRRAMMYSIIIDA.
}

\section{Genus EDMONDIA de Koninck.}

\author{
Emmoxida crassa 11. sp.
}

Plate X11, figures 8, 9.

Shell of medium size, transverse, subelliptical. Greatest width about $1 \frac{1}{3}$ the greatest height. Minge line straight, about one-half the entire wilth. Lower margin gently convex. Posterior outline broally rounded, somewhat truncated. Anterior end more narrowly rounded than the other. Beaks rather large and prominent. Convexity high, more compressed over the posterior portion.

Surlace markeil by strong, coarse, rather regular concentric striæ.

This species is rather more similar to certain Pennsylvanian types than to Mississippian ones, and if found at the higher horizon it might almost pass without challenge as Edmondia aspinwallensis, E. ovata, or E. subtruncata. In the Mississippian, E. burlingtonensis is a related species, but probably the most similar of all is E. illinoisensis, from which it can be distinguished by being regularly somewhat less transverse. Different specimens vary somewhat in proportions. A narrower, more nearly circular type represented by figure 9 may prove a listinct variety, in which case the name suborbiculata may be used to distinguish it from the other.

IIorizon and locality.-Moorefield shale, Batesville quadrangle, spring ('reek (stations 1248T, 2048, 2049b).

\section{NUCULIDA.}

Genus NUCULA Lamarck.

\section{Nucula rectangula McChesney.}

Plate XII, figures 13-17.

1860). Nucula rectungulu. McChesney, Desc. Now Species Pal. Foss, p. 74. (Date of imprint, 1859.)

Uamilton group: Near Batesville, Ark.

1565. Nucula rectungulu. McChesney, Illustrations New Species Foss., pl. 7, figs. 5a-c.

18tis. Nucula? rectangult. Mcchesney, Chicago Acad. Sci., Trans., vol. 1, p. 40, pl. 7, figs. 5a-c. (Date of imprint, 1867-1869.)

Jark-colored Hamilton shales: Batesville, Ark.

MeChesney says:

Shell small, subtriangular in outline, somewhat compressed. Ventral margin very hroadly rounded, sometimes almost straight; posterior margin sharply rounded; cardinal line and anterior slope nearly at right angles to each other, the former of which is straight and the latter slightly curved; beaks small, incurved, approximate, pointing toward and almost terminating the anterior extremity. Hinge line, on the posterior side of the beak, marked by about eight comparatively strong teeth, and on the anterior side by four or five teeth not quite so prominent. 
Surface marked by fine concentric striæ, and by some stronger lines of growth.

(ienlogical position and locality.-In dark-colored shales of the age of the Hamilton rucks of New York, near Batesville, Arkansas.

Mrchesney's description is given in full above because the original work is not always easy of access, and because there seemed less need for a description of the material actually in hand, since it came from the same beds and perhaps even the same locality as the original specimens.

Our fossils are few in number and it would appear that this is one of the rare species of the fauna. They agree with McChesney's description and figures, and without question belong to the species which he described under this title. Our specimens are preserved for the most part as internal molds, on which the scars, owing to the fact that the shell was very thick, as is common in this genus, are sharply defined. There is a large anterior adductor and above it a small pedal scar. The scar of the posterior adductor is indistinct, as represented also in McChesney's figures.

IIorizon and locality.-Moorefield shale, Batesville quadrangle, Spring Creek (station 1248A); Marshall quadrangle, Marshall (station 7039).

\section{LEDID $A$.}

\section{Genus LEDA Schumacher.}

\section{Leda vaseyana McChesney.}

Plate XI, figure 7 .

1860. Nuculites vaseyana. McChesney, Desc. New Species Pal. Foss., p. 73. (Date of imprint, 1859.)

Hamilton group: Batesville, Ark.

1865. Nuculites vaseyana. McChesney, Illustrations New Species Foss., pl. 7, figs. 4a-d.

1868. Nuculana Vaseyana. McChesney, Chicago Acad. Sci., Trans., vol. 1, p. 37, pl. 7, figs. 4a-d. (Date of imprint, 1867-1869.)

Hamilton group: Batesville, Ark.

MeChesney says:

Shell small, nearly twice as long as wide, moderately compressed, most gibbous on the umbones, broadly rounded at the anterior end, rapidly tapering from the beaks toward the posterior extremity, which is narrow and sharply rounded; beaks situated about one-third the length of the shell from the anterior extremity, very small, closely approximate, pointing posteriorly; cardinal line, posterior of the beak, elevated into a sharp ridge, ventral margin gently and regularly curving; hinge with from twelve to sixteen comparatively strong teeth, about equally distributed on the anterior and posterior sides of the beak.

Surface marked by very fine elevated concentric striæ, which conform to the border of the shell. Interior of the shell (as shown by the depression on casts) has a somewhat strong and elevated ridge rising from beneath the beak and passing obliquely downward, reaching the edge at about the center of the ventral margin; which character places it under the genus Nuculites of Conrad. 
This shell is very much the form of Leda polita (nobis), but the concentric strixe are coarser, and the shell is not so ventricose; but the internal structure at once separates it from that, as well as from all other species of Leda.

Geological position and locality. - In shales of the age of the Hamilton rocks of New York, Batesville, Ark.

This species was described without any question from the Moorefield shale and therefore belongs in the present discussion. At the same time no specimens have come to hand that can definitely be assigned to it. We have a few specimens from the same region from which the originals of $L$. vaseyana were obtained, but they seem to belong to another species, unless the differences which undoubtedly exist between them and McChesney's description and figures can be explained as adventitious. A single specimen from the same horizon at Marshall has been referred to $L$. vaseyana. It is a very indistinct impression and has the beak apparently rather more terminal.

As my own fossils are too poor to describe or figure and as McChesney's description and figures occur in a rather rare work I have reproluced them for the present occasion.

IIorizon and locality.-Moorefield shale, Batesville quadrangle, Spring Creek (McChesney); Marshall quadrangle, Marshall (station $703 \mathrm{sc}(?))$.

\section{LEDA NASUTA Hall?}

Plate XI, figure 6 .

1856. Nucula nasuta. Hall, Albany Inst., Trans., vol. 4, p. 17. (Date of imprint, 1858-1864.

Warsaw limestone: Spergen Hill, Ind.

1882. Nuculana nasuta. Whitfield, Am. Mus. Nat. Hist. Bull., vol. 1, p. 57, pl. 7, figs. $7-9$.

Warsaw division: Spergen Hill, Ind.

1883. Leda nasuta. Hall, Dept. Geology and Nat. Hist. Indiana, Twelfth Rept., 1882, p. 344, pl. 30, figs. $7-9$.

[Warsaw limestone]: Spergen Hill and Lanesville, Ind.

1906. Nuculana nasuta. Beede, Dept. Geology and Nat. Res. Indiana, Thirtieth Ann. Rept., 1905, p. 1324, pl. 23, figs. 7-9.

Salem limestone: Spergen Hill, Ellettsville, Stinesville, and Romona, Ind.

Of this type our collection contains three specimens, all internal molds. From the locality and horizon at which they were found one would be inclined to identify them with Leda vaseyana McChesney, but the characters hardly agree with that species sufficiently to warrant an identification. The beak is too nearly central and the anterior or longer side relatively too short. In these characters the form agrees more closely with $L$. nasuta, at least with the figures of one of Hall's types. The other figures, representing perhaps the more dominant variety, show the shell distinctly higher over the posterior portion and more rapidly tapering to the pointed anterior end. 
Horizon and locality.-Moorefield shale, Batesville quadrangle, Spring Creek (station 1248A2).

PARALLELODONTID $A$.

Genus PARALLELODON Meek.

Parallelodon multiliratus Girty.

Plate XII, figures 3, 4 .

1909. Parallelodon multiliratus. Girty, U. S. Geol. Survey, Bull. 377, p. 39, pl. 3, figs. 4, 5 .

Caney shale: Atoka and Tishomingo quadrangles, Oklahoma.

This species is abundant in one of our collections from the Moorefield shale, but the specimens are apt to be imperfect and poorly preserved. Few if any specimens exceed $25 \mathrm{~mm}$. in width and the average is smaller. The height is unusually great for the width, the two dimensions being in the ratio of 1 to $1 \frac{1}{2}$ or 1 to 2 . The shape is subovate, contracting rather strongly toward the front. The beak is only a short distance from the subangular cardinal extremity. The convexity is low and the umbonal ridge not very prominent or angular.

The surface is crossed by fine, subequal radiating liræ, which become still finer anterior to the umbonal ridge. In some specimens the liration is finer than in others.

I feel little doubt about the identity of these Moorefield shells with those from the Caney shale, which I described as Parallelodon multiliratus. The two fragmentary specimens which constitute the types both belong to the finely lirated section. There are in the Moorefield shale specimens with sculpture quite as fine, while others have it slightly coarser. One of the types represents the transverse and the other the compact form of the species, both of which occur in the Moorefield shale. It is quite possible that in the transverse shells the proportions have been somewhat modified by compression.

This is a rather well-marked species, characterized by its compact shape, low and regular convexity, and very fine liration. P.truncatus and $P$. newarkensis appear to be the most closely related forms.

Horizon and locality.-Moorefield shale, Batesville quadrangle, Spring Creek (1248R, 2049a, 2049c, 2053).

\section{Genus CYPRICARDINIA Hall.}

\section{Cypricardinia? moorefieldana n. $\mathrm{sp}$.}

Plate XII, figures 1, 2.

Shell rather large, transverse, subovate, rapidly narrowing toward the front. The height is to the width about as 1 to $1 \frac{1}{2}$. The cardinal line is nearly three-fourths of the entire width. The lower margin is gently convex, rounding up at the ends. The beak is but slightly 
posterior to the regularly rounded anterior extremity. Posterior outline subtruncate, slightly oblique, with a distinct cardinal angle, and a broadly rounded posterior-inferior outline. Convexity moderate, chiefly localized along the median portion. I'mbonal ridge not distinct. Postcardinal slopes compressed.

Surface marked by regular concentric strix at rather distant intervals. Intermediate ones are sometimes developed so that some specimens are more closely striated than others. No distinct traces of radiating lira have been detected. The right valve bears two long linear posterior teeth.

This form appears to represent a type of shell which has sometimes been referred to Macrodon (=Parallelodon), sometimes to Cypricardinia. It diflers from trpical Parallelodon in being less transverse and more rapilly contracting toward the front. The anterior extension of Parallelodom is longer and more angular. The seulpture of Parullelodon consists of persistent radiating costr, while in the present group there are strong regular concentric stria or imbricating concentric lamolla upon which the costæ, when present, are not persistent. I am by no means sure that these shells are quite distinct from Parallelodon, though probably they form at least a subgeneric group, but they seem to be less closely allied to it than to Cypricardinia.

Cypricardinia? moorefieldana occurs associated with Parallelodon multiliratus, and upon a casual examination might be mistaken for it, but it is distinguished by the regular concentric strix and the absence, so far as can be determined, of distinct radiating liræ. Of described species probably Macrodon hamiltonix and M. ovatus are the most similar. M. hamiltonix is more obliquely truncated behind and has distinct radial stria. M. ovatus also is more obliquely truncated and is more rapidly contracting toward the front.

IIorizon and Tocality--Noorefield shale, Batesville quadrangle, Spring Creek (stations 1248'T, 2049a).

\section{PTERIID A ?}

\section{Genus CANEYELLA Girty.}

\section{Caneyelia vaughani Girty.}

Plate XI, figure 12.

1909. Caneyella vaughani. Girty, U. S. Geol. Survey, Bull. 377, p. 35, pl. 4, figs. 7-10. Caney shale: McAlester, Stonewall, and Tishomingo quadrangles, Oklahoma.

Our collection contains only one specimen of this species, consisting of only a little more than half of the shell. While I have personally little doult that it belongs to the species which in the Caney shale I described as Caneyetla vaughani, it is not possible to establish this fact heyond question. 
The horizon of this and several other species is considerably above the calcareous basal portion of the Moorefield shale, to which Professor Williams gave the name of "Spring Creek limestone," and it may have belonged to the horizon of the Batesville sandstone, though such is not thought to be the case.

Horizon and locality.-Moorefield shale, Batesville quadrangle, Moorefield (station 2051b).

\section{Caneyella wapanuckensis Girty?}

1909. Caneyella wapanuckensis. Girty, U. S. Geol. Survey, Bull. 377, p. 34, pl. 3, figs. 6-11.

Caney shale: Tuskahoma, Antlers, Atoka, McAlester, and Tishomingo quadrangles, Oklahoma.

The single fragmentary specimen is extremely suggestive of the species named above, but its imperfect condition leaves a reasonable doubt as to whether it actually belongs to that species.

Horizon and locality.-Moorefield shale, Marshall quadrangle, Marshall (station 7039).

\section{Caneyella percostata Girty.}

Plate XI, figures 10, 11.

1909. Caneyella percostata. Girty, U. S. Geol. Survey, Bull. 377, p. 37, pl. 4, figs. 2-6. Caney shale: McAlester, Atoka, and Tishomingo quadrangles, Oklahoma.

The shells referred to this species are small and subovate, with a strongly oblique axis, nearly terminal beaks, and narrow arched anterior portion. The posterior wing is broad and the lower portion swung backward so as to project considerably beyond the hinge line, whose length is somewhat more than half the greatest width. The postcardinal angle is obtuse and somewhat rounded. The surface is marked by concentric undulations and a few coarse, strong, widely spaced costæ. There can, I think, be no doubt that this is the same species which I have described from the Caney shale under the name $C$. percostata. The Moorefield specimens are, however, a trifle smaller.

Horizon and locality.-Moorefield shale, Batesville quadrangle, Spring Creek (station 2052).

\section{Caneyella nasuta Girty.}

Plate XI, figures 8, 9.

1909. Caneyella nasuta. Girty, U. S. Geol. Survey, Bull. 377, p. 37, pl. 3, figs. 12-14.

Caney shale: Tuskahoma and Antlers quadrangles, Oklahoma.

At station 2052 a small species of Caneyella occurs in considerable abundance, but for the most part in a very fragmentary condition. The specimen figured is the most complete, and it is representative 
of the rest. The shape is elongate-ovate, very oblique, with a relatively long arched anterior extremity. The beak is small and strongly anterior, but not terminal. The hinge line is more than half as long as the entire width, and the body of the shell, projecting far behind it, causes the posterior outline to be so strongly oblique that the post-cardinal angle is hardly perceptible. The surface is marked by concentric striæ and undulations and by numerous rather fine, obscure, radiating costæ.

The shells having the foregoing characters occur with others in which radiating costæ appear to be entirely absent. In young stages the hinge scems to be shorter and the obliquity less strong.

I feel little hesitation in identifying this as C. nasuta, though some minor differences exist between specimens. Even from the original material this was seen to be a rather variable form. The specimen selected for illustration appears to have a shorter hinge line than two of the originals from the Caney shale (which are, after all, not very distinct in regard to this matter), but they agree with the third specimen.

IIorizon and locality.-Moorefield shale, Batesville quadrangle, Spring Creek (station 2052a).

\section{TRIGONIID $A$.}

\section{Genus SCHIZODUS King.}

\section{Schizodus Batesvillensis Weller.}

Plate XII, figure 5.

1897. Schizochus batesvillensis. Weller, New York Acad. Sci., Trans., vol. 16, p. 266, pl. 20, figs. 8, 9. (Date of imprint, 1898.)

Batesville sandstone: Batesville, Ark.

A few specimens from the Moorefield shale probably belong to the species which Mr. Weller described from the same general locality, but from a slightly higher horizon, as $S$. batesvitlensis. They are not very perfect, but when restored from the growth lines the shape agrees too well with Weller's figures to warrant separating them as a distinct species. They agree even more closely with the shell from the Maxville limestone which Whitfield figures under the title Schizodus chesterensis. I agree with Mr. Weller in believing that that citation should be placed in the synonymy of $S$. batesvillensis, having indeed formed the opinion from his figures before reading the statement in the text.

IIorizon and locality.-Moorefield shale, Batesville quadrangle, Spring Creek (station 2048); Marshall quadrangle, Marshall (station 7() $38 \mathrm{e}(?))$. 
PECTINID $A$.

Genus DELTOPECTEN Etheridge.

\section{Deltopecten batesvillensis Weller.}

Plate XI, figures 1-4.

1897. Aviculopecten batesvillensis. Weller, New York Acad. Sci., Trans., vol. 16, p. 263, pl. 19, figs. 3, 4. (Date of imprint, 1898.)

Batesville sandstone: Batesville, Ark.

This species is abundant in the Moorefield shale, and as the specimens are better preserved than in the Batesville sandstone, from which the originals were obtained, I am able to add somewhat to $\mathrm{Mr}$. Weller's description.

The largest specimen examined has a length of $36 \mathrm{~mm}$., considerably greater than any example which I have seen from the Batesville sandstone. The proportion of length and width varies in different specimens, but usually the length is the greater. The axis is slightly inclined backward. The umbo is always situated anterior to the middle of the hinge line, which it sometimes divides almost in the proportion of one to two. The lower part of the shell is subcircular, the anterior portion projecting beyond the end of the hinge line. The outline of the posterior side is concave, more so in some specimens than in others, and when it is nearly straight the posterior wing is relatively large, and it is always larger than the anterior. In the right valve this wing (the anterior) is defined by a deep angular byssal sinus. Where preserved in limestone the left valve is rather strongly convex, with a prominent pointed beak. Specimens preserved in the sandy calcareous shale are flatter. The anterior wing is abruptly and strongly depressed and its boundary is consequently distinct, but the posterior wing is undefined.

The right valve is nearly flat. The posterior wing is undefined, but the anterior is defined by a narrow groove and by a deep sinus in the outline.

The sculpture of the left valve consists of moderately coarse, strongly rounded ribs separated by narrow deep striæ. The ribs vary, being subequal in some specimens, distinctly alternating in others, and of three sizes in still others. It is difficult to determine whether new ribs arise by division of older ones or by intercalation. If by the former method, the ribs do not bifurcate equally but divide into larger and smaller, thus maintaining for the larger unit a more or less uniform size throughout. In cases where the costæ are conspicuously unequal, however, equal bifurcation takes place, the larger ones in many cases being incompletely divided by a median 
groove. The costae decrease in size and definition toward the sides, those on the wings becoming suddenly much finer and more like lire than costax; they are often not preserved on molds of the interior. Those on the anterior wing are few and widely separated.

There are also regularly arranged concentric crenulations which are fine and lamellose and especially strong and conspicuous on the wings.

The right valve is marked by costæ, but by much finer ones than those on the other valve, as is the custom in this group. Those on the wings are even much finer than those on the body of the shell, and the anterior wing has only three or four. Crenulations appear to be absent or inconspicuous over the body of the shell, but are high, thin, and closely arranged on the wings.

While the character of the hinge plate is not shown by our specimens, this form is referred to Deltopecten with some confidence because of its close agreement with $D$. occidentalis.

IIorizon and locality.-Moorefield shale, Batesville quadrangle, Spring Creek (stations 1237R, 1248R4, 1248Rx, 2048, 2049a(?), 2049b, 2049(1), Moorefielı (station 2051b), Howards Wells (station 1248X).

\section{Deltopecten? sp.}

Plate XI, figure 5 .

Pectinoid shells are not rare in the lower part of the Moorefield shale, but all thus far obtained seem to represent a single species, that which Mr. Weller described from the same region, but from a somewhat higher horizon, as Aviculipecten baiesvillensis. Only one specimen can be excepted, a right valve, which I am unable definitely to identify. It is a medium-sized shell with a length of $28 \mathrm{~mm}$. and a width about the same. The umbo divides into nearly equal parts the hinge line, which is about one-half as long as the greatest willth. The wings are small, the posterior not as well defined from the borly of the shell as the other, which is nearly isolated by the deep byssal sinus. The convexity is low and the axis is slightly inclined backward.

The surface is marked by not very distinct, closely arranged, concentric striæ. Costre there are none save on the anterior wing, which has two or three, slender and widely separated.

This shell is clearly distinct from the right valves of $D$. batesvillensis, having a higher convexity, a different shape, and especially a different sculpture, since it is without radial costæ.

Horizon and locality.-Moorefield shale, Batesville quadrangle, Spring ('reek (station 2049a). 


\section{PHOLADELIID A.}

Genus ALIERISMA King.

Allerisma WALKeri var. ABBREviatum n. var.

Plate X, figure 11 .

The fossils included in this group are of such a generalized type and the essential characters are so far unknown that I am a little uncertain under what genus to cite them. They suggest a rather strongly transverse Edmondia or a rather compact Allerisma, to which genus they may provisionally be referred. To some extent ther suggest two species in the fauna of the Batesville sandstone, and there may be some question as to whether their affinities lie rather with $A$. walkeri or with the associated form which Mr. Weller described as $A$. arkansanum, but which I suspect to belong to quite another group-that of Schizodus. They are more broadly rounded behind than $A$. arkansanum and have the concentric plications continued quite across the shell. On this account it seems probable that they are more closely allied to A. walkeri. They are uniformly less transverse than $A$. walkeri and it seems desirable on this account to recognize them as a distinct variety. The Waverly species A. cuyahoga is rather closely comparable, but I hesitate to make an identification with a species of which I have no specimens and which occurs in so different an area and faunal assoeiation. When poorly preserved, it is not always easy to distinguish specimens of this form from Schizodus batesvillensis.

IIorizon and locality.-Moorefield shale, Batesville quadrangle, . Spring Creek (station 2048).

GASTROPODA.

\section{PLEUROTOMARIIDA.}

Genus BEMBEXIA Oehlert.

Bembexia nodimarginata McChesney.

Plate VII, figures 1-5.

1860. Pleurotomaria nodomarginata. McChesney, Desc. New Species Pal. Foss., p. 70. (Date of imprint, 1859.)

IIamilton group: Near Batesville, Ark.

1865. Pleurotomaria nodomarginata. McChesney, Illustrations New Species Foss., pl. 7, figs. 1a-c.

1868. Pleurotomaria nodomarginata. McChesney, Chicago Acad. Sci., Trans., vol. 1, p. 47 , pl. 7, figs. 1a-c. (Date of imprint, 1867-1869.)

Hamilton group: Near Batesville, Ark.

1884. P'lenrotomaria nodomarginata. Walcott, U. S. Geol. Survey, Mon. 8, p. 259, pl. 18, fig. 15.

Lower Carboniferous: Eureka district, Nevada. 


\section{McChesney says:}

Shell rather small; spire elevated conical, composed of from three to four volutions; length of the shell equal to one and a half its greatest diameter. Volutions somewhat angular, flattened above and rounded below, having the periphery marked by a narrow flattened or slightly concave spiral band; outer volutions joining onto the prereding ones just below the band; suture well marked, scarcely canaliculated. Columella straight, produced below, which makes the distance below the spiral band at the commencement of the last volution considerably more than half the entire length of the specimen. Border of the lips thin, gently receding toward the middle; notch shallow, axis solid.

Surface marked by coarse transverse striæ, of equal strength above and below the band, and which are gently recurved toward the notch, conforming to the border of the lip, and more abruptly on the spiral band. These striæ, when seen through a lens, present somewhat the appearance of projecting lamellæ. At the upper edge of the volution every alternate stria is elevated, forming a sort of elongate node, which are sometimes elevated so as to present the appearance of a band of nodes; the striæ between die out at the commencement of the nodes.

This shell is of the same type as $P$. sulcomarginata of Conrad, from the Hamilton rocks of New York, but is a much longer shell, the surface markings are proportionately coarser, the nodes near the upper margin of the volution are very much larger and commence at the earliest ages of the shell, while those of the other species are not developed until the shell is nearly half grown. It is also destitute of the second row of small nodes a little above the revolving band, which forms a conspicuous feature in I'. sulcomarginata.

Geological position and locality: In shales of the age of the Mamilton group of New York, near Batesville, Ark.

The foregoing is McChesney's original description. My shells, which must have come from nearly the same locality and horizon, present the following characters:

Shell small, conical, consisting of three or four rapidly expanding volutions. Greatest height somewhat greater than the greatest diameter. Final volutions about two-thirds of the whole. Peritreme section subquadrate with a broad, strongly elevated carina about milway. Upper external surface nearly flat, strongly declining; lower external surface gently convex. Suture not strongly depressed. Spire rather regularly conical. Axis imperforate. Volutions embracing up to the carina. Sculpture consisting of strong, angular, regular ridges which swing backward with the convex side outermost, most prominent near the suture. Below the slit band, which is situated on the carina, the ridges or costæ are more nearly transverse or less strongly directed backward. The slit itself is deep.

This species differs from $B$. shumardi, the only other representative of this group from the Mississippian, in its smaller size, lower spire, less transverse whorl section, and corrugated surface.

Horizon and locality.-Moorefield shale, Batesville quadrangle, Spring Creek (stations 1248A1(?), 1248A2(?), 1248R5, 2048, 2049, 2053). 


\section{BELLEROPHONTID A.}

\section{Genus BUCANOPSIS Ulrich.}

\section{Bucanopsis cancellata Hall?}

1856. Bellerophon cancellatus. Hall (not B. cancellatus Hall, 1847), Albany Inst., Trans., vol. 4, p. 31. (Date of imprint, 1858-1864.)

Warsaw limestone: Bloomington and Spergen Hill, Ind.

1877. Bellerophon textilis. Hall, Miller's Am. Pal. Foss., p. 243.

1882. Bellerophon textilis? Whitfield, Am. Mus. Nat. Hist., Bull., vol. 1, p. 90, pl. 8, figs. 4,5 .

Warsaw division: Spergen Hill and Bloomington, Ind.

1883. Bellerophon textilis. Hall, Dept. Geology and Nat. Hist. Indiana, Twelfth Rept., p. 371, pl. 31, figs. 4, 5.

Warsaw group: Spergen Hill, Lanesville, and Bloomington, Ind.

1884. Bellerophon textilis* Walcott, U. S. Geol. Survey, Mon. 8, p. 257, pł. 18, fig. 18. Lower Carboniferous: Eureka district, Nevada.

1897. Bucanopsis textilis. Ulrich, Geol. Survey Minnesota, Final Rept., vol. 3, pt. 2, p. 854 .

1906. Bucanopsis textilis. Beede, Dept. Geology and Nat. Res. Indiana, Thirtieth Ann. Rept., 1905, p. 1362, pl. 25, figs. 4, 5.

Salem limestone: Spergen Hill, Bloomington, Paynters Hill, Harrodsburg, and Stinesville, Ind.

This form is represented by a fragmentary specimen with imperfectly preserved. sculpture. The latter consists of fine revolving liræ crossed by more widely spaced transverse lamellæ. While it is highly probable that this shell belongs to Hall's species, the specimen is too incomplete to make the identification certain.

Overlooking the fact that he had in 1847 used Bellerophon cancellatus for an Ordovician species, Hall in 1856 introduced the same name for the present one, changing it later to Bellerophon textilis. The original B. cancellatus has since been shown to be a Protowarthia, just as the present one has been shown to be a Bucanopsis. It becomes possible, therefore, to return to the original name in the present case.

Horizon and locality.-Moorefield shale, Batesville quadrangle, Spring Creek (station 2049a).

\section{Genus BELLEROPHON Montfort.}

\section{Bellerophon sp.}

Under this title are included three specimens, internal molds, whose affinities are much in doubt. The shape impresses me rather as that of Euphemus or Bellerophon ss., while Patellostium is clearly not among them, nor probably Bucanopsis. As among these three genera, however, the position is not positively determinable.

Horizon and locality.-Moorefield shale, Batesville quadrangle, Spring Creek (stations 1248R4, 2048). 


\title{
CAPULIDA.
}

\section{Genus STROPHOSTYLUS Hall.}

\author{
Strophostrous afl". carleyanus Hall."
}

Plate VII, figure ti.

This species is represented by five or six imperfect specimens which seem to be closely related to the species named above, but no definite identification is possible with the present material. The only specimen showing the spire is rather small and appears to have the earlier volutions little if at all elevated above the final one. If this is a normal example, it doubtless represents a species or variety distinct from IIall's.

IIorizon and localit!.-Moorefield shale. Batesville quadrangle, Spring Creck (stations 1248R4, 2048, 2049b), Moorefield (station 2051 ?).

\section{CEPHALOPODA.}

\section{ORTHOCERATIDA.}

Genus ORTHOCERAS Bruyn.

\section{Orthoceras aft. (mebriliratum Girty. ${ }^{b}$}

Under this title are included two specimens, one much smaller than the other and from a slightly different horizon. The siphuncle is large and subcentral, the shell straight and gradually tapering, and the chambers low. From 2! to 3 occur in a diameter. The sculpture is unknown. The larger fragment has a diameter of about $8 \mathrm{~mm}$. and the smaller a diameter of about $2 \mathrm{~mm}$.

In its proportions this shell more nearly approaches $O$. crebriliratum than any other, but the chambers are not quite so high. Inasmuch as the sculpture is not known, a satisfactory identification is impossible. Should that feature prove to be in agreement, however, it would probably not be desirable, because of the slight difference in the height of the chambers, to discriminate it from O. crebritiratum.

IIorizon and locatit!--Moorefield shale, Batesville quadrangle, Spring Creek (stations 1248A2, 2049a).

\section{OrThoceras sp. $a$ \\ Plate XIll, figure 1.}

Under this title is included a single specimen representing a rather large rapidly expanding species. The example, which is $95 \mathrm{~mm}$. long, has a diameter of $26 \frac{1}{2} \mathrm{~mm}$. at the large end and $16 \mathrm{~mm}$. at the small

n Hall, Trans. Alhany Inst., vol. 4, 1856, p. 31; Whitfield, Bull. Am. Mus. Nat. Hist., vol. 1, 1882, p. 71, pl. s. figs. 26, 27.

b Girty, G. H., Bull. L. S. Geol. Survey, No. 377, 1909, p. ti, pl. 6, figs. 9, 10. 
one. It is perfectly straight and appears to represent only the chamber of habitation, since no septa are visible. It is further characterized by a sculpture consisting of very fine, sharply raised lines, separated by relatively broad intervals. The intervals vary greatly in size, the larger being as much as three times the width of the smaller; they are irregular, being curved locally without any apparent regard to orientation; in places a later set cuts diagonally across an earlier one.

Horizon and locality.-Moorefield shale, Batesville quadrangle, Moorefield (station 2051c).

Orthoceras sp. $b$.

This group includes two specimens, apparently chambers of habitation. They are large and smooth, the larger having a diameter of about $25 \mathrm{~mm}$. They differ from species a in the smoothness of their surface. The larger was found associated with specimens identifierl as Bactrites? carbonarius, but it has been placed under a separate heading because of its large size. The smaller one may belong to that species, however, for at least that difference does not exist.

Horizon and locality.-Moorefield shale, Batesville quadrangle, Spring Creek (station 2052a), Moorefield (station 2051).

\section{TAINOCERATID $\boldsymbol{A}$.}

\section{Genus ENDOLOBUS Meek.}

Endolobus ornatus n. sp.

Plate XIII, figure 2.

This form is known only from a fragment representing the outer chamber. When complete it may have had a diameter of $40 \mathrm{~mm}$. or less. The volutions enlarge rapidly, are but slightly embracing, and have a wide umbilicus exposing all the earlier volutions. The cross section is transversely elliptical with pointed ends. The larger end of the fragment has a width of $20 \mathrm{~mm}$. and a height of $13 \mathrm{~mm}$. The ventral surface is less strongly arched than the dorsal, which has a narrow impressed zone, not found, however, on the earlier portion of the shell. Aside from the sculpture, which consists of numerous fine, sharp, revolving liræ, the surface is smooth, except for broad indistinct constrictions confined to the sides, to which they give an obscurely nodose appearance. In addition to the revolving liræ already mentioned, there are regular lamellose growth lines, doubtless following the shape of the aperture and indicating the presence of a deep emargination or hyponomic sinus across the middle of the ventral surface. The siphuncle is large and situated a little to the ventral 
side of the middle. The height of the chambers is not known. The suture is nearly straight across the ventral surface with perhaps a broad indistinct saddle, and there is a deep angular lobe on the middle of the dorsum. On either side of the annular lobe the suture appears to be slightly elevated to form an obscure saddle.

This species resembles E. spectabilis but is much smaller. It is safe to say that when of the same size E. spectubitis would present quite different characters, and if this form attained the size of E. spectabilis other differences would be found. This species also has transverse and revolving sculpture, a feature not found in E. spectabilis and even said to be foreign to the genus.

Horizon and locality.-Moorefield shale, Batesville quadrangle, Moorefield (station 2051c).

BACTRITID $A$.

Genus BACTRITES Sandberger.

Bactrites? carbonarius smith.

Plate XIII, figures $3,4,5$.

1903. Bactrites carbonarius. Smith, U. S. Geol. Survey, Mon. 42, jl. 6, figs. 9-11.

Fayetteville shale: Near Moorefield, Ark.

The original specimens of this species were olstained from the Moorefield shale at Moorefield, Ark. The Survey collection contains a few fragments from the same locality, but they are smaller and much less perfect. The other characters, however, are similar, and there can be little question that they really belong to Smith's species.

Horizon and locality.-Moorefield shale, Batesville quadrangle, Moorefield (station 2051).

\section{Bactiotes? smithinanus Girty.}

1909. Buctrites? smithiumus. (iirty, L'. S. Geol. Survey, Bull. 377, p. 53, pl. 6, figs. 5,6 .

(aney shale: Atoka, Stonewall, and Tishomingo quadrangles, Oklahoma.

The specimens under consideration were obtained at Batesville in the "Spring Creek limestone" and differ from the Moorefield examples identified as B.? carbonarius in being much smaller and in having the chambers relatively longer. In the latter the diameter at any point is about equal to $1 \frac{1}{2}$ the height of the chambers, while in these lit tle specimens the height of the chambers and the diameter are equal. It is possible that $B$. carbonarius in its immature condition has relatively longer chambers than when of large size, but, on the other hand, in B.? smithianus we have a species in which the chambers show the same proportions as in the specimens under consideration. B.? smithianus, so far as known, does not attain the size of B.? carbona- 
rius, but these specimens are -very small even for B.\& smithianus. Those which show the septa have a diameter of $2 \mathrm{~mm}$., while a larger unsegmented fragment is twice as large. The typical specimen of B.? smithianus has a diameter of only $6 \mathrm{~mm}$.

IIorizon and locality.-Moorefield shale, Batesville quadrangle, Spring Creek (station 1248A1).

\section{GLYPHIOCERATIDA.}

Genus GONIATITES de Haan.

\section{Goniatites choctawensis Shumard.}

Plate XV, figures $\cdot 1-7$.

1863. Goniatites choctawensis. Shumard, Acad. Sci. St. Louis, Trans., vol. 2, p. 109. Coal Measures: Choctaw Nation.

1903. Goniatites choctawensis. Smith, U. S. Geol. Survey, Mon. 42, p. 67. Bend formation: Choctaw Nation (?), Ind. T.

1903. Goniatites striatus. Smith (non Sowerby ?), idem, p. 80, pl. 10, figs. 1-11; pl. 26, figs. 6-13.

Fayetteville shale: Batesville, Ark.

Bend formation: near Lampasas, Tex.

1909. Goniatites choctawensis. Girty, U. S. Geol. Survey, Bull. 377, p. 59, pl. 13, figs. 1-11.

Caney shale: Tuskahoma, Antlers, McAlester, Tishomingo, and Stonewall quadrangles, Oklahoma.

As I noted in discussing this species from specimens obtained in the Caney shale, there are found among the latter two varieties of this form, one distinguished most obviously from the other by being somewhat narrower over the ventral surface with the sides more distinctly expanding toward the umbilicus. It was likewise noted that a third variation was found in specimens from the Moorefield shale from Moorefield, Ark. The latter are distinguished by having the sculpture somewhat coarser and by retaining the predominance of the transverse over the radiating sculpture (a youthful character of this group) until a considerably later period. That is, shells from the Caney shale show continuous revolving liræ with only faint transverse crenulations, while those from Moorefield of the same size show transverse lamellæ with strongly crenulated margins. Of these three groups that from Moorefield is perhaps the most distinct and deserving of varietal recognition. Yet I am somewhat doubtful of the advisability of recognizing it. Such observations as I have made on these shells would indicate that they. are liable to local variations in matters of detail, all the specimens from one locality, it may be, showing one group of characters and all from another showing the same group more or less modified from the first occurrence. These occurrences doubtless represent somewhat different horizons as well as different locali$46447^{\circ}-$ Bull. $439-11-7$ 
ties, but whether the differences of character remain true to horizon is yet to be demonstrated.

From the Moorefield shale our specimens are obtained from three different localities, all, however, only a few miles apart-Moorefield, Spring Creek, and Howards Wells. Those from Moorefield have already been referred to, while the specimens from Spring Creek are all diminutive and doubtfully identified. Our specimens from Howards Wells are poorly preserved, but they are characterized by having at an early stage fine revolving liræ with subordinate transverse liræ. In other words, they agree not with the shells obtained at Moorefield, but with the typical variety obtained from the Caney shale, especially with the one having parallel sides. This is true with but one exception, a small specimen measuring $13 \mathrm{~mm}$. in diameter which has the coarse sculpture and transverse crenulated lamellæ of the Moorefield form. Other specimens of the same size show fine continuous revolving liræ. From these facts it seems doubtful to me whether it would serve any useful purpose to discriminate the Moorefield form.

Smith seems to include these shells under Goniatites striatus Sowerby. He remarks: ${ }^{a}$

There seem to be among the American specimens two rather well-marked varieties of this species, one with the spiral lines very sharp and the cross striæ very weak; this one occurs in the St. Louis-('hester stage of Batesville, Ark.; the other has the spiral lines and cross striæ of about equal strength, and very sharply defined crenulations; this occurs in the St. Louis-('hester stage, the Bend formation of central Texas (Glyphioceras cumminsi $\mathrm{Hyatt}_{\mathrm{p}} \mathrm{pl} . \mathrm{x}$, figs. 1-11), although it seems to the writer that Hyatt has included under this designation specimens of both $G$. striatus and G. crenistria. In youth these varieties can not be distinguished from each other, nor from $G$. crenistria, which is associated with them.

These two varieties of $(\dot{r}$. striatus are very comparable to the two which I have here noted under $G$. choctawensis and I suspect that Smith's striatus is in the main equivalent to my choctawensis, although he suggests that choctawensis may be identical with $G$. crenistria.

Smith figures a specimen from Batesville having a diameter of about $9 \mathrm{~mm}$., which is marked by continuous liræ. Thus it appears that his specimens from Batesville agree with our specimens from IIowards Wells, while our specimens from Moorefield are more in agreement with Hyatt's Glyphioceras cumminsi, which Smith apparently did not find in Arkansas at all. In fact, our fossils from Howards Wells show three phases. Most of them have a fine ornamentation of continuous revolving liræ. A young specimen $12 \mathrm{~mm}$. in diameter has this feature with strong, though distinctly subordinate, transverse lamellæ. Another of about the same size has cumminsi characters, i. e., coarser ornamentation of nearly equally transverse and revolving lines; while a third has the sculpture more fine but about equally cancellated.

a Smith, J. P., The Carboniferous ammonoids of America: Mon. U. S. Geol. Survey, vol. 42,1903, p. 81. 
It may possibly prove desirable to recognize three or even more varieties of this form, but for the present $I$ am referring all to a single species, as Smith has done. I am, however, citing them under $G$. choctawensis Shumard, because, though their relationship to G. striatus and $G$. crenistria is undoubted, their exact specific identity has not been shown.

As above noted, Smith suggests that $G$. choctawensis is the same as $G$. crenistria (not striatus). In the synonymy of $G$. crenistria he includes $G$. incisum Hyatt, described from Texas, a species which I think is related to Gastrioceras richardsonianum and G. kingi, while under it he describes and figures certain fossils from the Moorefield shale. G. crenistria of Smith, as based on Arkansas fossils, I confess, appears to me to resemble one of the groups here included under $G$. choctawensis, so that that species as interpreted by me may prove to contain Smith's G. striatus and part of his G. crenistria. G. crenistria (as possessing the characters of $G$. incisum) does not occur in the Survey collections, and in case my surmise regarding Smith's specimens is correct, it is not known from the Moorefield shale at all unless his identification of $G$. calyx is based upon an immature representative of the species. For the present, however, I am assuming that Smith actually found specimens in the Moorefield related to G. incisum; and under G. choctawensis I am citing his identification of $G$. striatus, which I believe to be based on the same types of shells.

My figures of a specimen in the Survey collection (figs. 7, 7a) represent one of the two types found in the Moorefield shale and here included under G. choctawensis; the figures copied from Smith appear to represent the other. It is possible that the form may really be the same form which he identified as G. crenistria, but I am convinced that it is distinct from $G$. incisum, which he places in the synonymy of G. crenistria. At the same time, as noted above, Smith seems to recognize two groups under $G$. striatus which are distinguished in the same manner as the two groups that I have here described as belonging to $G$. choctawensis.

Horizon and locality.-Moorefield shale, Batesville quadrangle, Spring Creek (1248A1(?), 1248A2(?)), Moorefield (stations 2051, 2051c), Howards Wells (station 1245A).

Goniatites CRenistria Phillips. ${ }^{a}$

Plate XV, figures 8, 9.

183.6. Goniatites crenistria. Phillips, Geology of Yorkshire, pt. 2, p. 234, pl. 19, figs. 7-9.

Mountain limestone: Bolland; Queens County; Fermanagh; Isle of Man.

1884. Glyphioceras crenistria. Hyatt, Boston Soc. Nat. Hist., Proc., vol. 22, p. 329.

1893. Glyphioceras incisum. Hyatt, Geol. Survey Texas, Fourth Ann. Rept., p. 471, pl. 47, figs. 44-48.

Carboniferous: Near Richland Springs, San Saba County, Tex.

$a$ For foreign synonymy and distribution, see Smith, loc. cit. 
1897. Glyphiocerns incisum. Smith, California Acad. Sci., Proc., (3), Geology, vol. 1, no. 3 , p. 111, pls. 13-15.

Fayetteville shale: Moorefield, Independence County, $\Lambda \mathrm{rk}$.

1903. Goniatites crenistria. Smith, U. S. Geol. Survey, Mon. 42, p. 68, pl. 10, figs. 12-16 (?); pl. 14; pl. 15; pl. 16, figs. 1a-j; pl. 26, figs. 1-5.

(?) Bend formation: Texas.

Spring ('reek limestone (Fayetteville shale): Moorefield and Boles, $\Lambda$ rk.

Smith cites this species from two areas in North America-from Texas, where IIyatt describes it under the name of $G$. incisum, and from $\Lambda$ rkansas. IIyatt both describes and figures $G$. incisum as being marked by transverse lamellix entirely without crenulations. It appears to be closely similar in external appearance, at least, to the form from the White Pine shale of Nevada, which Hall and Whitfield described as Gastrioceras kingi, and to that from the Caney shale of Oklahoma which I described as fiastrioceras richardsonianum.

In his description of $G$. crenistria, based, it would appear, on specimens from Arkansas, Smith speaks of fine, sharp crenulations and a finely reticulate surface. Furthermore, his figures look much like the fossils from the same locality and horizon which I have called Goniatites choctawensis. I am assuming, however, that his Arkansas shells belong to the same species as that from Texas which Hyatt called $G$. incisum and that both belong to the European species G. crenistria. It is on this assumption and on the strength of Smith's specimens that G. crenistria is cited from the Moorefield shale, for the Survey collections contain no form which I would associate with G. incisum.

I am not entirely satisfied, however, that G. crenistria, as determined by Smith on Arkansas fossils, is the same as G.incisum Hyatt (whether it is identical with ( $\dot{r}$. crenistria is still another matter); and I suspect that the latter may prove to be congeneric with Gastrioceras kingi and $G$. richardsonianum. If this suspicion has any grounds it may be that $G$. crenistria is, after all, present in our collection and that I have included it with $G$. choctawensis. I have, in fact, included under that title two distinguishable types, one having the transverse sculpture coarser than the other and the revolving liræ initiated at a distinctly later period. It may be that the latter variety is what Smith calls $G$. crenistria and that the other is his $G$. striatus. At the same time he himself recognizes two sections of $G$. striatus which seem to bear the same relation to one another as the two sections which $I$ have mentioned in $G$. choctawensis. It may be well to recall in this connection that I am using $G$. choctawensis for the same form which he calls $G$. striatus.

The fossils which Smith calls G. crenistria appear to have come from the Moorefield shale at Moorefield, Ark. In describing the occurrence he records it as "from the Spring (reek limestone, so-called Fayetteville shale, of Arkansas," and proceeds in the next paragraph to state 
that some of his figured specimens were "from Moorefield, Ark., from calcareous nodules in shales associated with an undoubted St. Louis fauna, and others from the same formation near Boles, Ark." This may be merely two ways of saying the same thing, but if so he does not elsewhere recognize the "Spring Creek limestone" at Moorefield.

This form as determined by Hyatt's G. incisum is very suggestive, at first glimpse, of the Caney species, Gastrioceras richardsonianum, but it has a slightly smaller umbilicus. Professor Smith's Arkansas fossils referred to the same species show still more important differences, having at maturity crenulated cross striæ but being distinctly unlike in the larval condition.

Horizon and locality.-Moorefield shale, Batesville quadrangle, Moorefield (fide J. P. Smith).

\section{Goniatites SUbCIRCULARIS Miller.}

Plate XIV, figures 7, 8 .

1889. Goniatites subcircularis. Miller, North Am. Geology and Pal., p. 440, fig. 741. St. Louis group: Crab Orchard, Ky.

1903. Goniatites subcircularis. Smith, U. S. Geol. Survey, Mon. 42, p. 81, pl. 26, figs. 14-18.

Fayetteville shale: Batesville, Ark.

Smith cites this species from the Moorefield shale at Batesville, but it is not represented in the Survey collection. It might be questioned whether the shells which I have called Gastrioceras caneyanum do not really belong here. The large specimen of that species which I have figured from Howards Wells clearly has a much larger umbilicus and probably does not belong to G. subcircularis. Smith states. that $G$. subcircularis, as represented by his specimens, is entirely without crenulations. The imperfect specimens from Howards Wells, provisionally referred to G. caneyanum, are clearly crenulated, and the single fragment from Batesville seems to retain traces of such markings, though the specimens, being rather poorly preserved, might have failed to preserve the crenulations, even if these were originally present.

Horizon and locality.-Moorefield shale, Batesville quadrangle, Batesville (fide J. P. Smith).

\section{Goniatites Newsomi Smith.}

Plate XIV, figure 1.

1903. Goniatites newsomi. Smith, U. S. Geol. Survey, Mon. 42, p. 78, pl. 17, figs. 2-5. Fayetteville shale: Batesville, Ark.

1909. Goniatites newsomi. Girty, U. S. Geol. Survey, Bull. 377, p. 62, pl. 12, figs. 11, $11 \mathrm{a}$.

Caney shale: Antlers quadrangle, Oklahoma.

This species was described by Smith from the Moorefield shale at Batesville. Specimens representing $G$. newsomi are not found in the 
collection studied, the most closely related being certain shells which I have identified as Gastriocerus caneyanum. As the suture and ontogeny of our shells are unknown, they may really belong to Smith's species rather than to my own. The best preserved appear to be distinctly less globose than $G$. newsomi, with a shape more like $G$. subcircularis but with a larger umbilicus.

Horizon and locality.-Moorefield shale, Batesville quadrangle, Batesville (fide J. P. Smith).

\section{Genus GASTRIOCERAS Hyatt.}

\section{Gastrioceras richardsonianum Girty?}

Plate XIV, figures 2, 3.

?1903. Glyphioceras calyx. Smith, U. S. Geol. Survey, Mon. 42, p. 62, pl. 18, figs. 1-11. Fayetteville shale: Moorefield, Ark.

1909. Gastrioceras richardsonianum. Girty, U. S. Geol. Survey, Bull. 377, p. 54, pl.11, figs. 1-11.

Caney shale: Antlers, Atoka, McAlester, Tishomingo, and Tuskahoma quadrangles, Oklahoma.

The specimens upon which this extremely provisional identification is based have not come under my personal observation, but were described and figured by J. P. Smith as Gastrioceras calyx Phillips. His specimens were obtained from the Moorefield shale at Moorefield. Smith calls attention to the fact that this species is marked by larval characters and that it may be merely an immature condition of some indeterminate form. The youthful condition of G. richard: sonianum of the Caney shale, a species which was not described at the time he wrote, has an immature stage extremely suggestive of the form which he figures as G. calyx, and I believe it probable that they will prove to be the same species, although a positive conclusior is not justified without additional evidence.

Horizon and locality.-Moorefield shale, Batesville quadrangle Moorefield (fide J. P. Smith).

\section{Gastrioceras Caneyanum Girty.}

Plate XIV, figure 6.

1909. Gastrioceras caneyanum. Girty, U. S. Geol. Survey, Bull. 377 , p. 57, pl. 15, figs. 4-10.

Caney shale: Tuskahoma, Antlers, McAlester, Stonewall, and Tishoming quadrangles, Oklahoma.

Under this title are included the large specimen represented by my figure and three or four smaller examples. All are more or less fragmentary and none shows the suture, so that this important ai in the determination of the species is not available. In external characters, however, there is a close agreement, except as noted below 
I do not regard the identification as a very doubtful one, although complete affirmative evidence is not at hand.

If the large figured specimen were not interpreted as macerated and flattened it might be regarded as more discoidal than the Caney specimens, but it very clearly has been flattened, and, this aside, agrees well with specimens from that formation. The smaller specimens from the Moorefield shale are somewhat more finely striated than Caney specimens and may perhaps be regarded as a variety, but I am doubtful whether it is practicable to employ slight variations in this particular in delimiting species, since the same individual shows marked changes at different stages of growth and since I believe these changes are liable to be accelerated or retarded in different individuals.

Horizon and locality.-Moorefield shale, Batesville quadrangle, Spring Creek (station 2052), Howards Wells (stations 1245A, 1245B).

\section{Genus EUMORPHOCERAS Girty. \\ Eumorphoceras bisulcatum Girty.}

Plate XIV, figure 4.

1909. Eumorphoceras bisulcatum. Girty, U. S. Geol. Survey, Bull. 377, p. 68, pl. 11, figs. 15-19.

Caney shale: Tuskahoma, Antlers, Atoka, McAlester, and Tishomingo quadrangles, Oklahoma.

To this species has been referred a single specimen in a rather poor state of preservation, which probably represents a senile condition and exhibits such variations from the figured specimens of E. bisulcatum from the Caney shale as such a condition would naturally show. The shape is even more discoidal, the height of the volutions increasing more rapidly than the width. In this case the greatest diameter must have been about $28 \mathrm{~mm}$., and the thickness $7 \mathrm{~mm}$. The two revolving sulci are retained in normal strength, but the plications near the umbilicus are fainter than in the typical specimens. They have the further peculiarity that the grooves are narrow relatively to the ridges, somewhat the reverse of the condition shown by the types; so that in the one form the configuration may be more aptly described as marked near the umbilicus by sulci, and in the other by pilæ. Great variation is, however, shown in the Caney specimens in the size of these plications.

In so far as the suture line is shown, it does not differ materially from that of E.bisulcatum, and as in the latter, so here also, constrictions are lacking.

But few of the Caney specimens have such size and character of preservation that they can be compared advantageously with 
the present example, but I can not feel that there is much doubt that the latter belongs to the same species.

IIorizon and locality.-Moorefield shale, Batesville quadrangle, Howard's wells (station 1245A).

Genus ADELPHOCERAS Girty.

Adelphoceras meslerianum Girty?

Plate XIV, figure 5.

1909. Adelphoceras mesterianum. (iirty, I. S. Geol. Survey, Bull. 377, p. 66, pl. 12, figs. 1-3.

('aney shale: Mc'Alester and Tishomingo quadrangles, Oklahoma.

Of this form our collection contains a single rather imperfect specimen which was found associated with the one identified as Eumorphoceras bisulcatum. It much resembles that specimen in general appearance and may prove to belong to the same species, since its real affinities are somewhat in doubt. It is, however, considerably smaller, less discoidal, with not only a relatively but also an absolutely larger umbilicus, and without the two conspicuous revolving sulci. The large umbilicus is a feature of $A$. mesterianum rather than of E. bisulcatum, but species of the latter vary considerably in this respect. The plications near the umbilicus at first suggest $E$. bisulcatum rather than A. meslerianum, but they are clearly distinct from those of typical $E$. bisulcatum, being larger, more irregular, and differently proportioned. In fact, they consist of the usual constrictions, which occur about five to a volution, with one or two short intermediate sulci extending part way up the sides. This is not quite the arrangement even of the large associated specimen referred to E. bisulcatum, because in that specimen complete periodic constrictions appear to be wanting, just as they are wanting in typical E. bisulcatum, another fact adverse to identifying this specimen with that species. Some suggestions of intermediate sulci can be observed in the typical specimens of A. meslerianum, but nothing comparable to this example. The latter bears very faint traces of two revolving sulci, a feature which is strongly marked in E. bisulcatum, but they are so obscured as to be a somewhat doubtful character. While not quite normal for A. meslerianum, in so far as that species is known, in this character the specimen seems less a departure from that species than from the other. In the suture, alsn, it seems to be more closely allied to $A$. meslerianum by reason of its pointed second lateral lobe and asymmetrical second lateral saddle.

Although not a normal specimen, it seems that of the two this form has more in common with A. mesterianum than with E. bisulcatum, but more complete material is needed before a conclusion can be reached as to whether it is really the same or a closely related species. I may add that a specimen almost identical with this in 
every way has been obtained from the Caney shale and referred to the latter species.

IIorizon and locality.-Moorefield shale, Batesville quadrangle, Howard's wells (station 1245A).

\section{TRILOBITA.}

PROETIDA.

\section{Genus GRIFFITHIDES Portlock.}

Griffithides? sp.

This species is represented by a single specimen, an imperfect free cheek. It is of rather large size and strongly and coarsely granulose. A complete description of this part can not be given. In its generic relations it is probably a Griffithides, but this can not be determined.

IIorizon and locality.-Moorefield shale, Batesville quadrangle, Spring Creek (station 2049a).

\section{OSTRACODA.}

\section{LEPERDITIID $A$.}

\section{Genus PARAPARCHITES Ulrich and Bassler.}

Paraparchites Nicklesi Ulrich.

Plate IX, figures 2-5.

1891. Leperditia nicklesi. Ulrich, Cincinnati Soc. Nat. Hist., Jour., vol. 13, p. 200, pl. 18, figs. la-e.

St. Louis group: Columbia, Monroe County, Ill.

The shells referred to this species are abundant in the lower part of the Moorefield shale at Batesville. The specimens agree well with the original description and figures, the chief differences being connected with the spine. This feature varies considerably in the specimens examined in two particulars. In some specimens the spine is very distinct and in others it is obsolete, or at least its presence can not be determined. Strangely enough, though the spine can usually be distinguished on the left valve, the valve on which it is represented in Ulrich's figure, I have not been able to discover it on a single one of the numerous right valves examincd. Even when best developed it seems to be not quite as prolonged as in the type specimens and perhaps deserves to be described rather as a raised point than as a spine. In position also it varies considerably and is seldom as close to the anterior angle as represented in the original figure. These shells also differ somewhat in the proportions of length to width and in configuration, some being more nearly equilateral than others.

Horizon and locality.-Moorefield shale, Batesville quadrangle, Spring Creek (stations 2048, 2049b). 
BEYRICHIID $A$.

Genus PRIMITIA Jones and Holl.

Primitia moorefieldana n. ip.

Plate IX, figures 6, 7 .

Shell rather small, transversely subovate, contracting distinctly though not strongly toward the anterior end, which is sharply rounded. Posterior outline slightly truncated and extencled. Convexity rather high, especially toward the anterior end, which is inflated; somewhat compressed posteriorly. The anterior and posterior margins are slightly flattened into a band or flange which is not persistent. Umbilical pit deep, elongate, considerably posterior to the middle.

This species is perhaps more similar to $P$. fayettevillensis than any other, but differs in having an indistinct flange before and behind, in having the umbilical point less central, and in having the convexity less regular. It much resembles $P$. granimarginata, but has not a persistent band nor any marginal granules. In the matter of the flange it resembles $P$. sulixquata, but differs from it in many other particulars.

Horizon and locality.-Moorefield shale, Batesville quadrangle, Spring Creek (station 204s).

CYPRIDA.

Genus BAIRDIA McCoy.

BAIRDIA ATTENTATA GIRTY.

1910. Bairdia attenuata. Girty, New York Arad. Sci., vol. 20, No. 3, pt. 2, p. 237. Basal Fayetteville shale: Fayetteville quadrangle, Arkansas.

A single specimen representing this species has come to hand. It is not very perfect, but in so far as its characters have been determined it agrees with the shell which $I$ have described from the basal Fayetteville as B. attenuata.

IIorizon and locality.-Moorefield shale, Batesville quadrangle, Spring Creek (station 2048). 


\section{REGISTER OF LOCALITIES.}

1237 R. Batesville quadrangle, Independence County, Ark., NW. $\frac{1}{4}$ SE. $\frac{1}{4}$ sec. 13 , T. 13 N., R. 7 W.

J. C. Branner, August, 1889.

1245A. Batesville quadrangle, Sharps Cross Roads, Independence County, Ark., Howards Wells, in SE. $\frac{1}{4}$ NE. $\frac{1}{4}$ sec. 28 , T. 14 N., R. 5 W.

R. A. F. Penrose.

1245B. Batesville quadrangle, Howards Wells. Specimen thrown out in digging well. Given by the proprietor, Mr. Howard.

1248A. Batesville quadrangle, Spring Creek, Independence County, Ark., in railroad cut east of trestle over wagon road. (See section on p. 12.)

Stuart Weller, July, 1891.

[248R. Batesville quadrangle, Spring Creek, Independence County, Ark.; H. S. Williams's section (see p. 12.)

H. S. Williams, 1890; Branner and Penrose, 1889.

1248T. Batesville quadrangle, Spring Creek, Independence County, Ark. Loose material on railroad embankment.

Stuart Weller, 1891.

1248V. Batesville quadrangle, Spring Creek, Independence County, Ark. Loose material on railroad embankment.

Stuart Weller, 1891.

1248W. Batesville quadrangle, Spring Creek, Independence County, Ark. Loose on railroad embankment.

Stuart Weller, 1891.

1248X. Batesville quadrangle, NE. $\frac{1}{4}$ SW. $\frac{1}{4}$ sec. 34, T. 14 N., R. 5 W. Fayetteville [Moorefield] shale, Independence County, Ark.

W. B. Norville.

1248Y. Batesville quadrangle, Batesville, Ark., Spring Creek, railroad embankment. Stuart Weller, July 14, 1891.

1248Z. Batesville quadrangle, Spring Creek. Débris along railroad bank.

Stuart Weller, July 16, 1891.

2048. Batesville quadrangle, Ruddell's mill on Spring Creek, $2 \frac{1}{2}$ miles west of Batesville, Ark.

E. O. Ulrich and G. I. Adams, September 8, 1902.

2049. Batesville quadrangle, Batesville, Ark. "Spring Creek limestone," $2 \frac{1}{2}$ miles west of town. Cut on Spring Creek railroad above Ruddell's mill; about same as 2048 .

G. H. Girty, September 12, 1907.

2049a. Batesville quadrangle, Ruddell's mill, $2 \frac{1}{2}$ miles west of Batesville, Ark. A single loose block of "Spring Creek limestone."

G. H. Girty, September 11 and 12, 1907.

2049b. Batesville quadrangle, same as 2049a. Another loose block.

G. H. Girty, September 11 and 12, 1907.

2049c. Batesville quadrangle, same as 2049a. Another loose block.

G. H. Girty, September 11 and 12, 1907. 
2049d. Batesville quadrangle. Railroad ballast adjacent to cut at Ruddell's mill and evidently from the "Spring Creek limestone."

G. H. Girty, September 11 and 12, 1907.

2049e. Batesville quadrangle. Miscellaneous loose fossils at 2049.

G. H. Girty, September 11 and 12, 1907.

2049f. Batesville quadrangle. Loose material from lower Moorefield shale, Spring Creek, Ark.; same locality as 2049a.

G. H. Girty, October 18, 1908.

2051. Batesville quadrangle, Moorefield shale, Moorefield, Ark.; hill opposite God frey's house.

G. H. Girty, September 13, 1907.

2051a. Batesville quadrangle, Moorefield shale, Moorefield, Ark.; stream back of Godfrey's house.

G. H. Girty, September 13, 1907.

2051b. Batesville quadrangle, Moorefield shale, Moorefield, Ark.; hill near Godfrey's house.

G. H. Girty, September 13, 1907.

2051c. Batesville quadrangle, Fayetteville [Moorefield] shale, Moorefield, Independence County, Ark.

Collected by C. E. Siebenthal and sent to H. S. Williams by J. P. Smith.

2052. Batesville quadrangle, a little north of White River Junction, 2 miles west of Batesville. From calcareous concretions near base of Moorefield shale; about 50 feet above "Spring Creek limestone."

G. H. Girty, September 11 and 12, 1907.

2052a. Batesville quadrangle, same section as 2052, but from black shale about 20 feet higher.

G. H. Girty, September 11 and 12, 1907.

2053. Batesville quadrangle, cut on main line about one-half mile west of White River Junction. "Spring Creek limestone."

G. H. Girty, September 12, 1907.

7038. Marshall quadrangle, bed of branch, one-half mile northeast of Marshall, Ark. Moorefield shale.

G. H. Girty, September 19, 1907.

7038a. Marshall quadrangle, same as 7038, but from sheety beds just below.

G. H. Girty, September 19, 1907.

7038c. Marshall quadrangle, little ravine in northeast part of Marshall, Ark. (stream marked as intersecting road on map); about 8 feet above top of Boone. Thin calcareous sandy band in black shale. Same locality and horizon as 7038.

G. H. Girty, October 11, 1908.

7039. Marshall quadrangle, same locality as 7038. Thin earthy limestone in black shale, 20 feet above Boone.

G. H. Girty, October 11, 1908. 


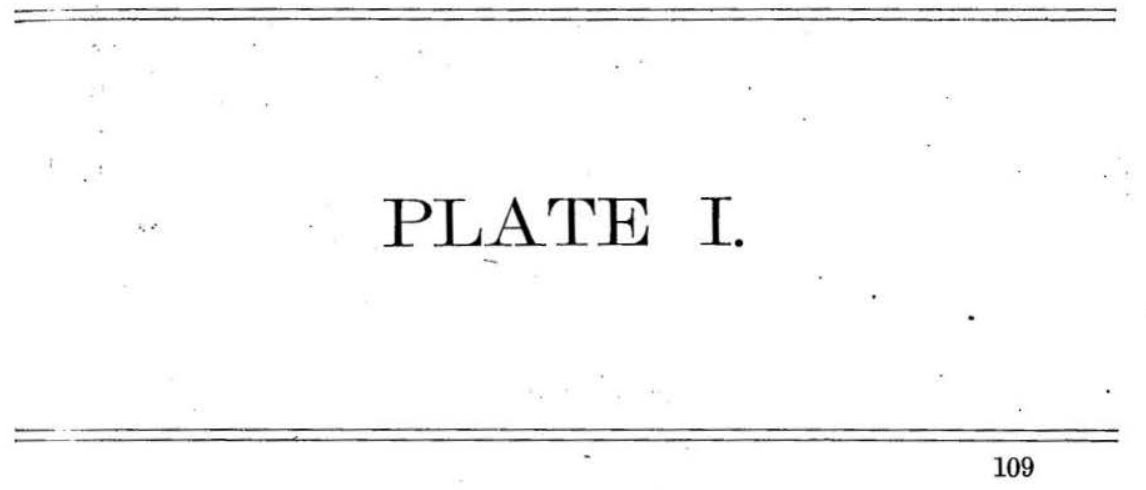




\section{PLATE I. \\ Lingula Batesvilla (p. 32).}

Figure 1. Internal mold of an imperfect ventral valve, $\times 3$.

2. Interior of a large ventral valve, $\times 3$.

3. Internal mold of a ventral valve, $\times 3$.

4. A testiferous specimen slightly exfoliated, $\times 3$. It is impossible to ascertain from the shape whether this is a dorsal or a ventral valve.

5. An exfoliated ventral valve of slightly different shape from the last, natural size.

6. A specimen retaining the dorsal and ventral valves in conjunction, preserved as an internal mold. Dorsal valve, natural size.

6a. Same, dorsal valve, $\times 3$.

6b. Same, ventral valve, natural size.

7. Interior of a dorsal valve showing also an impression of the apical portion of the corresponding ventral, $\times 3$.

8. Internal mold of a large, imperfect dorsal valve, showing strong vascular markings, $\times 3$.

9. Internal mold of an imperfect dorsal valve, $\times 3$.

10. Internal mold of a dorsal valve, $\times 3$.

Spring Creek, Ark. The originals of figures 1, 3, 4, 9, and 10 are from station 2049d; those of figures 2, 6, 7, and 8, from station 2048; that of figure 5 from station 1248R4.

\section{LiNGULA ALBAPINENSIS (p. 36).}

Figure 11. $\Lambda$ specimen provisionally referred to this species, natural size. Spring (reek, Ark. (station 1248A5). 
U. S. GEOLOGICAL SURVEY
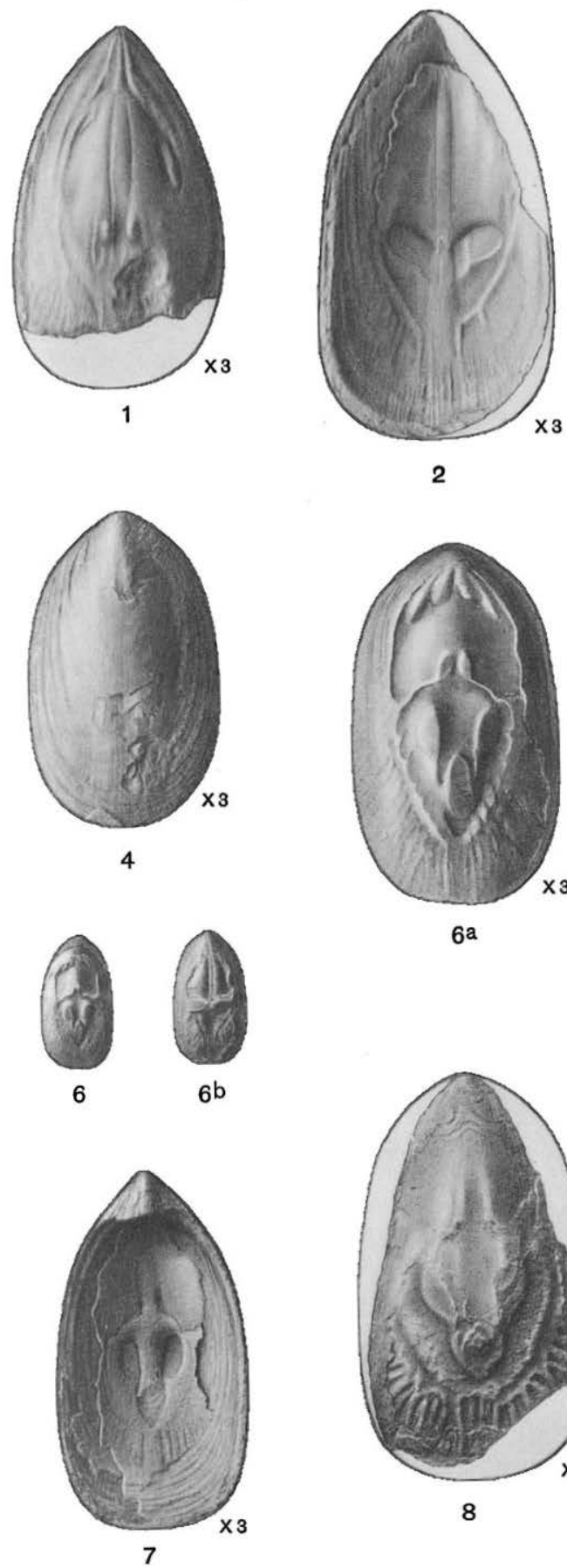

BULLETIN 439 PLATE I
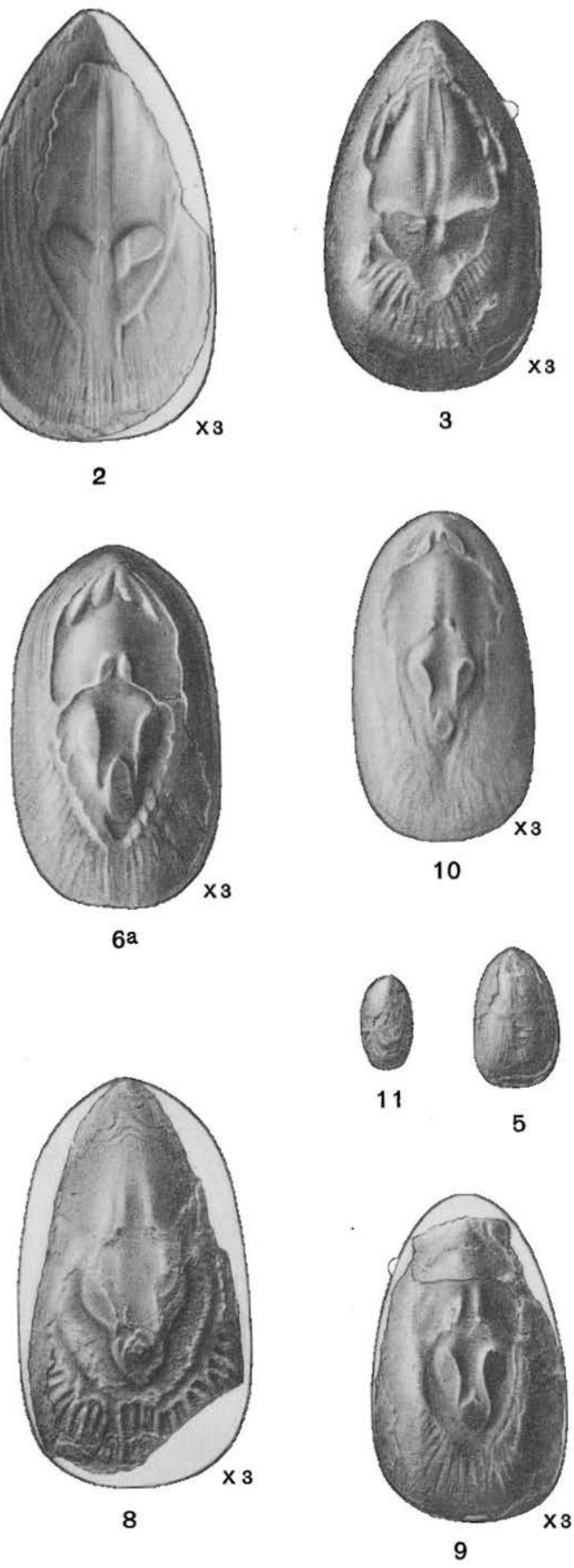

FAUNA OF THE MOOREFIELD SHALE 



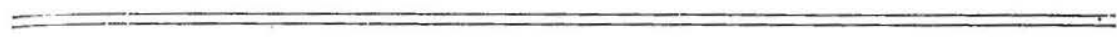

PLATE II.

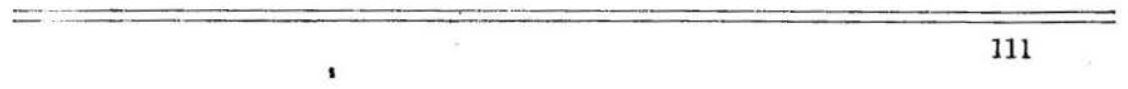




\section{PLATE II.}

LINGULIDISCLNA NEWBERRY Var. MARSHALLENSIS (p. 39).

lintire 1. A characteristic dorsal valve, seen from above.

1:. Same, side view in outline.

2. A dorsal valve of somewhat different shape irom the type, seen from above.

Zal. Same, side view in outline.

Marshall. Ark. (station 7038c).

3. A small dorsal valve, seen from above, $\times 3$.

3a. Same, side view in outline, $\times 3$.

Marshall, Ark. (station 7038).

IAngulidiscina Newberryi var. caneyana (p. 40).

Ficiure 4. A small dorsal valve, seen from above, $\times 2$.

4a. Same, sicle view in outline.

Monrefield, Ark. (station 2051).

5. Fxternal mold of a dorsal valve.

White River Junction, Ark. (station 205:3).

LINGLIIDISCINA NEWBERRY var. MOOREFIELDANA (p. 38).

Firithe 6. A dorsal valve. seen from above.

fia. Same, side view in outline.

7. Squeeze of a dorsal valve taken from the typical specimen, seen from above.

7a. Same, side view in outline.

Spring ('reek, Ark. (station 2049b).

LINGULIDISCINA NEWBERRYi var. OVATA? (p. 40).

Figure 8. Fxternal mold of what is probably a dorsal valve, referred to this species with some doubt.

White River Junction, Ark. (station 2053).

(honetes sericeus (p. 41).

Fitiule 9. A small dorsal valve.

9a. Same, $\times 3$.

Marshall, Ark. (station 7039).

Prodetctus arkansanus var. multiliratus (p. 43).

Figuze 10. A dorsal valve showing partly the internal surface and partly the impression of the external surface.

11. The reverse of figure 10 , showing in part the external surface and in part the impression of the internal. Spring (reek, Ark. (station 1248Y). 
U. S. GEOLOGICAL SURVEY

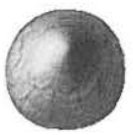

1

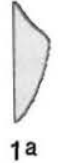

1a

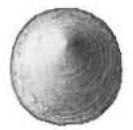

2

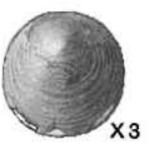

3

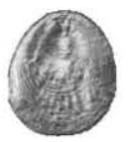

8

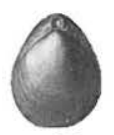

13
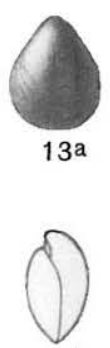

$13 b$

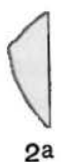

$2 a$

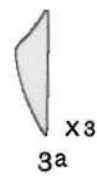

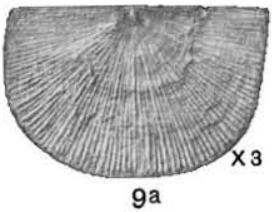

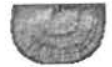

9
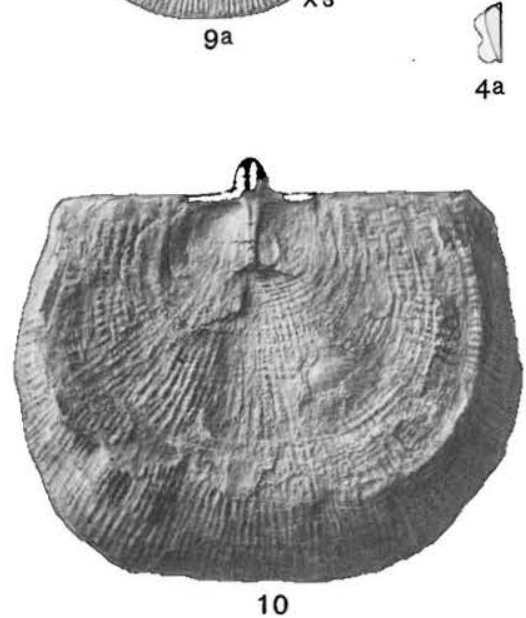

10
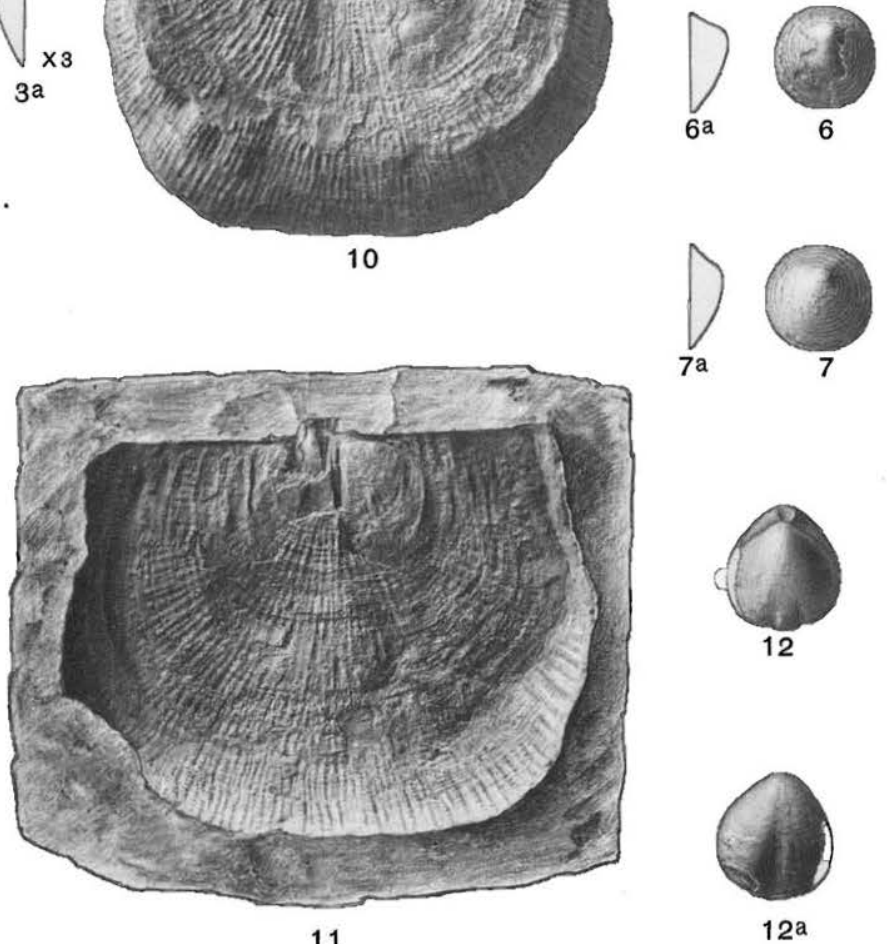

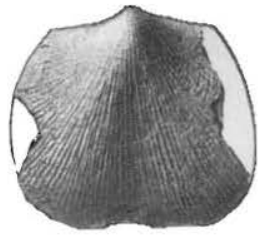

14

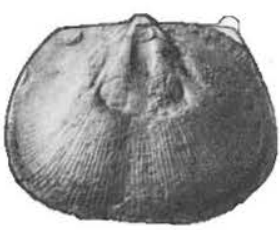

15

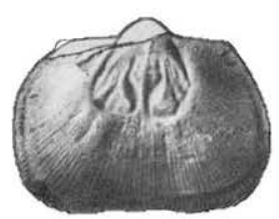

16

FAUNA OF THE MOOREFIELD SHALE 

HaRTtina BRevilobata (p. 65).

FIGURE 12. Dorsal view of an imperfect specimen referred to this species.

12a. Same, ventral view.

Spring Creek, Ark. (station 1248R4).

HaRtTina BREvilobata var. marginalis (p. 66).

Frgure 13. Dorsal view of a characteristic specimen. The two sulci of the dorsal valve are hardly perceptible.

13a. Same, ventral view.

13b. Same, side view in outline.

Spring Creek, Ark. (station 1248R4).

Rhipidomella arkansana (p. 53).

Figure 14. An imperfect ventral valve.

15. Internal mold of a dorsal valve.

16. Internal mold of a ventral valve.

Spring Creek, Ark. (station 2049a).

$46447^{\circ}-$ Bull. $439-11-8$ 

PLATE III. 


\section{PLATE III.}

\section{- Productella hirsutiformis (p. 50).}

Figure 1. A ventral valve flattened in shale.

Moorefield, Ark. (station 205la).

2. A partially exfoliated ventral valve.

Spring Creek, Ark. (station 1248A).

3. An external mold of a dorsal valve which shows toward the front traces of faint, radiating striæ.

4. External mold of a dorsal valve which shows also an impression of the area of the corresponding ventral.

Spring Creek, Ark. (station 2049).

Productella hirsutiformis var. Batesvillensis (p. 51).

Figure 5. A ventral valve which differs from the foregoing in the convexity and in the extension of the hinge line.

Spring Creek, Ark. (station 2049a).

\section{Productus moorefieldanus (p. 48).}

Figure 6. View of the anterior end of the typical ventral valve.

6a. Same, seen from above.

$6 \mathrm{~b}$. Same, side view in outline.

Spring Creek, Ark. (station 2049).

Productus moorefieldanus var. pusillus (p. 49).

Figure 7. External mold of a large dorsal valve.

7a. Same $\times 2$.

8. External mold of another dorsal valve.

8a. Same $\times 3$.

9. Internal mold of another dorsal valve of more transverse shape, $\times 3$.

Spring Creek, Ark. (The originals of figures 7 and 9 from station 2049a, that of figure 8 from 2048.)

\section{Productus biseriatus (p. 46).}

Figure 10. A dorsal valve of greater convexity than usual, $\times 2$.

Spring Creek, Ark. (station 2049c).

11. A characteristic dorsal valve preserved as a mold of the exterior.

Spring Creek, Ark. (station 2049a).

\section{Productus subsulcatus (p. 47).}

Figure 12. An internal mold of a ventral valve crushed in shale.

13. A typical dorsal valve preserved as a mold of the exterior.

14. A typical ventral valve preserved as an external mold crushed in shale

The spine bases are not conspicuous and not very elongate.

Spring Creek, Ark. (station 1248A2).

Productus subsulcatus var. Janus (p. 48).

Frgure 15. An internal mold of a ventral valve with very elongate spine bases.

Spring Creek, Ark. (station 1248A5). 
U. S. GEOLOGICAL SURVEY
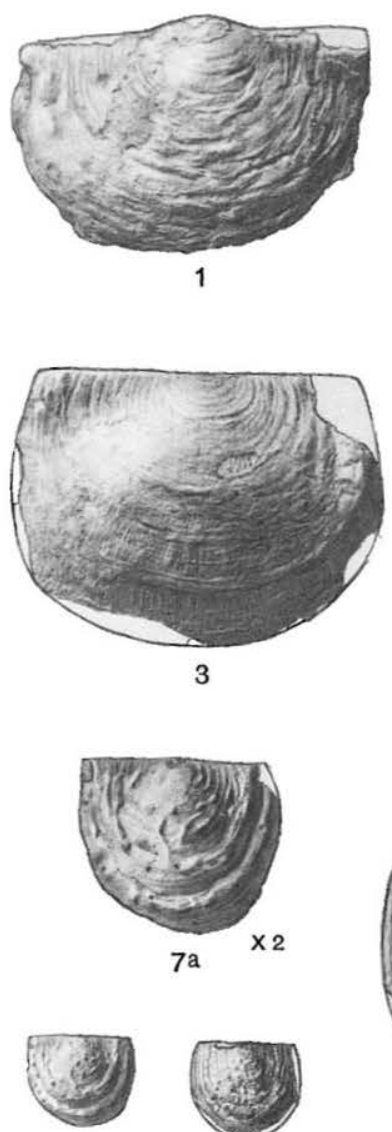

7

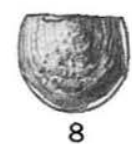

8
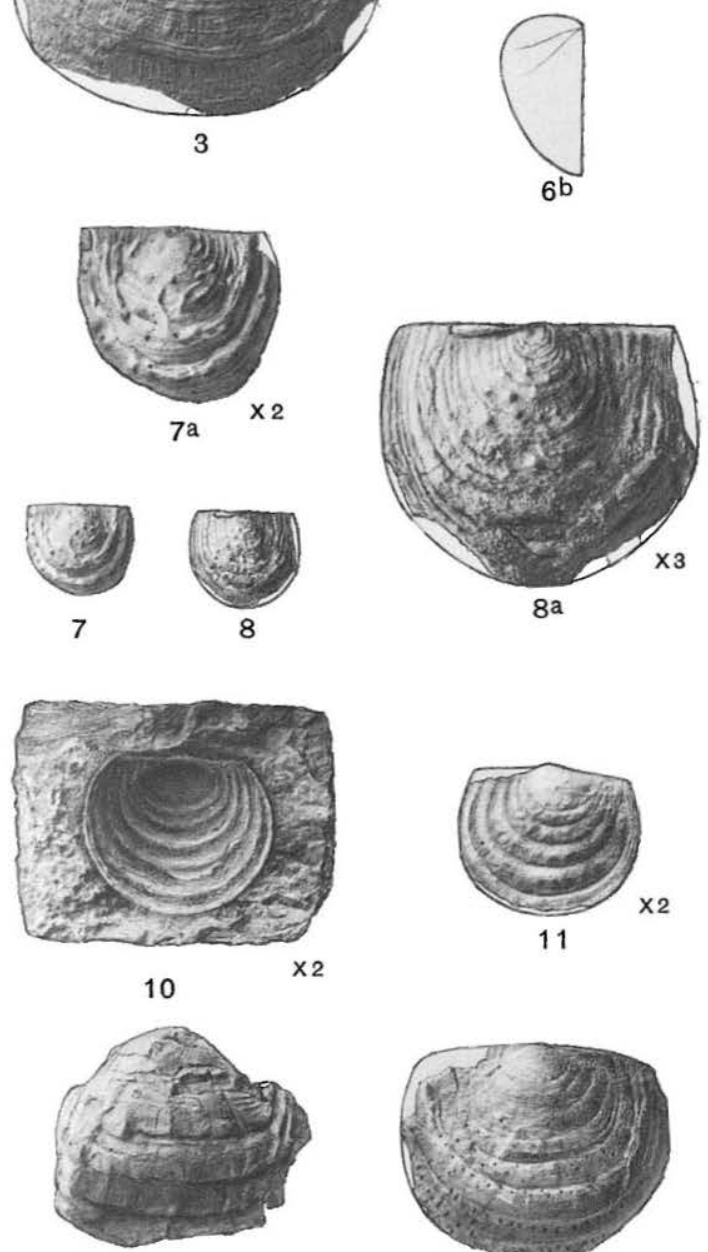

12
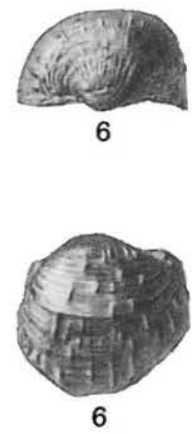

6

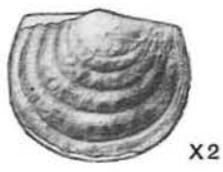

11

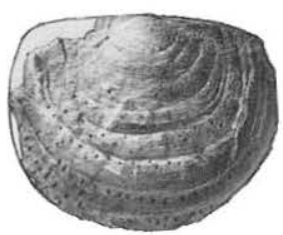

13
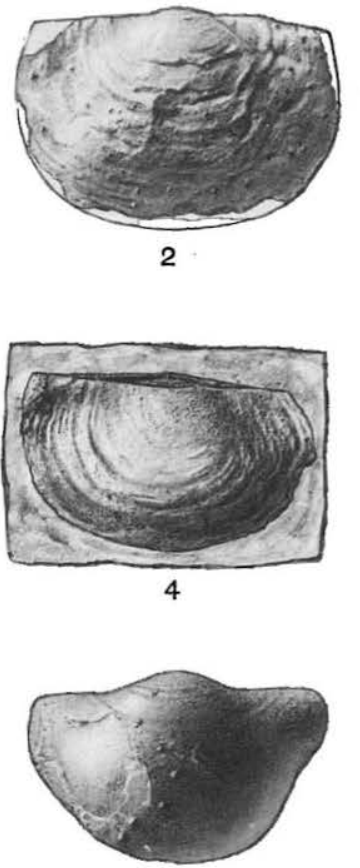

5
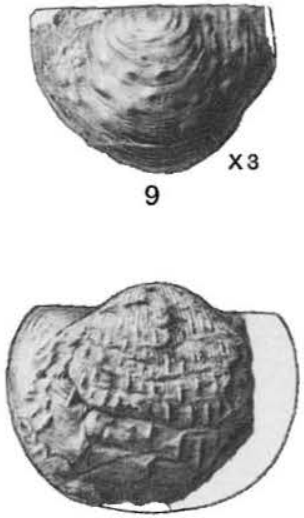

15

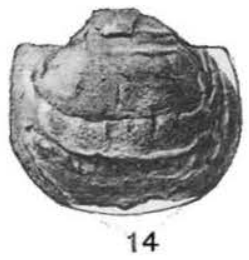

FAUNA OF THE MOOREFIELD SHALE 



\section{PLATE IV.}




\section{PLATE IV.}

\section{Productus pileiformis (p. 44).}

Figure 1. A thick-shelled, exfoliated ventral valve, seen from above, $\times 1 \frac{1}{2}$.

Spring Creek, Ark. (station 2049a).

2. Anterior view of a large ventral valve, somewhat crushed.

2a. Same, posterior view.

Spring Creek, Ark. (station 2049f).

Productus inflatus var. coloradoensis? (p. 42).

Figure 3. Imperfect ventral valve, seen from above.

3a. Posterior view of same.

Spring Creek, Ark. (station 2049c).

Diaphragmus elegans (p. 51).

Figure 4. Ventral view of a characteristic specimen of the form which occurs in the Moorefield shale.

5. Dorsal view of another specimen showing the internal plate.

Spring Creek, Ark. (station 1248R4).

Composita madisonensis var. pUsilla (p. 76).

Figure 6. A dorsal valve, seen from above.

7. A ventral valve, seen from above.

Spring Creek, Ark. (station 2049b).

Composita aff. Humilis (p. 77).

FigURE 8. A dorsal view of a young specimen with both valves in conjunction.

Spring Creek, Ark. (station 2048).

9. A dorsal valve, seen from above.

Spring Creek, Ark. (station 1248A2).

Composita subquadrata var. lateralis (p. 75)

Figure 10. An imperfect ventral valve.

Spring Creek, Ark. (station 1248R). 
U. S. GEOLOGICAL SURVEY
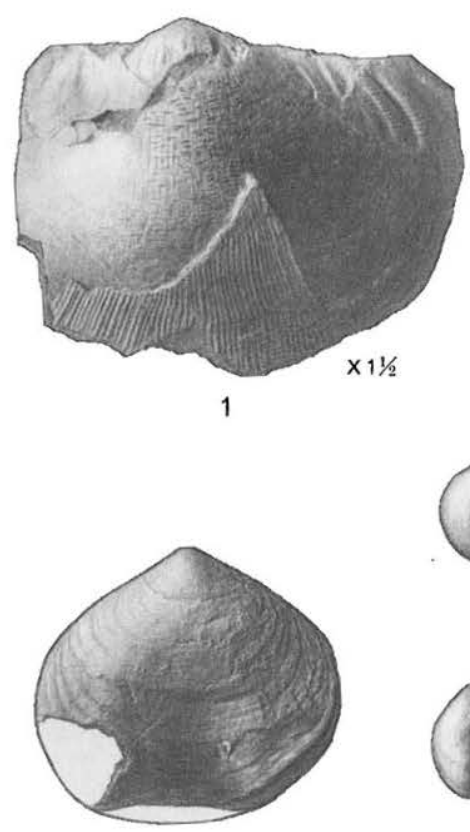

10

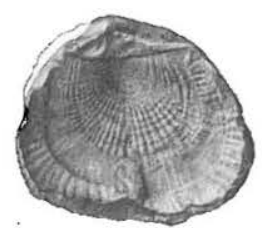

5
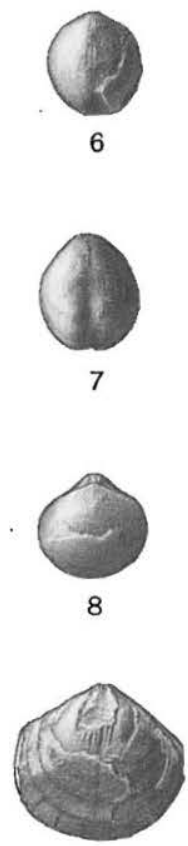

9
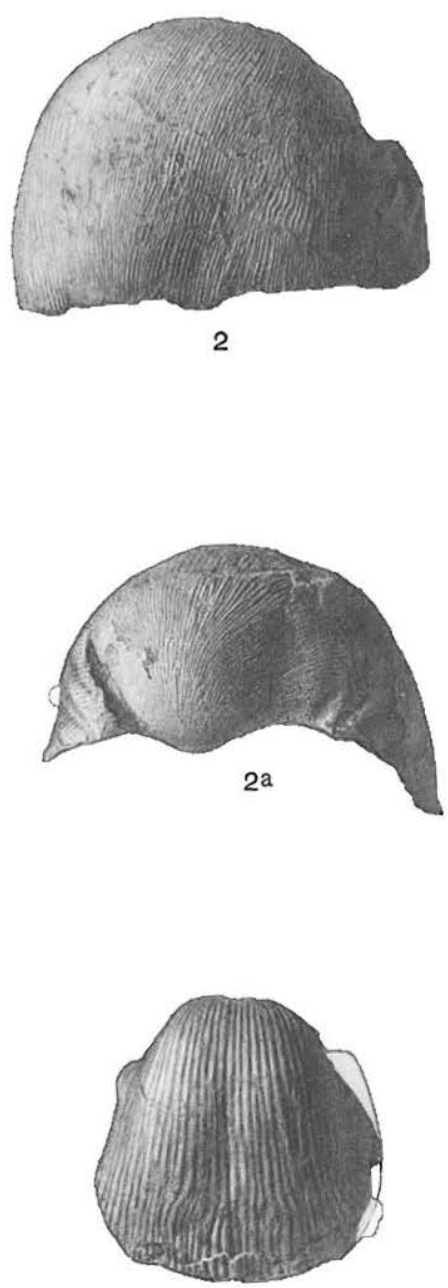

4

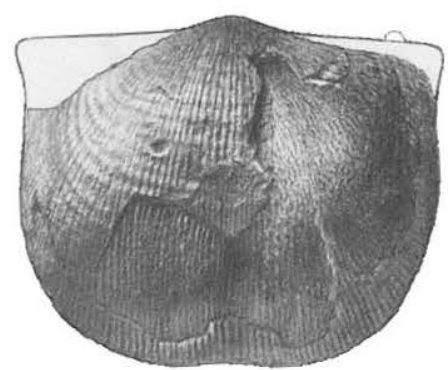

3

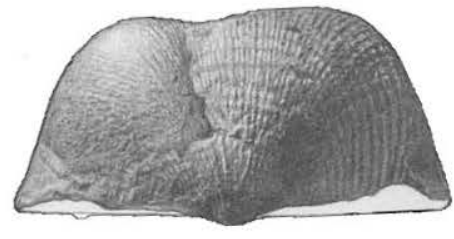

$3 a$

FAUNA OF THE MOOREFIELD SHALE 



\section{PLATE V.}




\section{PLATE V.}

Camarotógchia purduei var. agrestis (p. 60).

Frgure 1. Anterior view of a characteristic specimen with four plications on the fold.

1a. Same, dorsal view.

2. Dorsal view of a specimen with five plications on the fold.

2a. Same, anterior view.

3. A dorsal view of a gibbous specimen which has six unequal plications on the fold. This specimen is compressed or naturally one-sided.

3a. Same, anterior view.

4. Dorsal view of an explanate specimen with six equal plications on the fold.

4a. Same, anterior view. Spring Creek, Ark. (station 2049b).

Camarotechia purduei (p. 60).

Frgure 5. Dorsal view of a specimen which is indistinguishable from the typical variety.

5a. Same, anterior view.

Spring Creek, Ark. (station 2048).

Camarotechia purduei var. laxa (p. 61).

Figure 6. Dorsal view of a large specimen with four costæ on the fold. In some of the illustrations of this variety the plications are represented as a little too strong and angular.

6a. Same, anterior view in outline.

7. Dorsal view of a specimen with numerous lateral costæ.

7a. Same, ventral view.

7b. Same, anterior view in outline.

8. Dorsal view of a young specimen.

8a. Same, anterior view in outline.

9. Dorsal view of another young specimen.

9a. Same, anterior view in outline.

10. Dorsal view of a specimen with three costæ on the fold.

10a. Same, ventral view.

10b. Same, anterior view in outline.

11. Dorsal view of a specimen with five costæ on the fold. A very rare variation.

11a. Same, ventral view.

11b. Same, anterior view in outline. Marshall, Ark. (station 7039). 


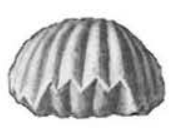

1

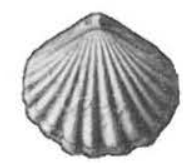

$1 \mathrm{a}$

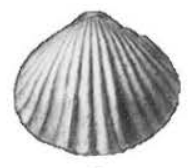

2

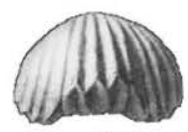

$2^{a}$

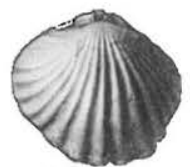

3

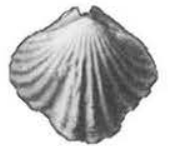

6

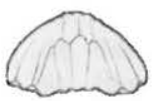

$6 a$

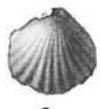

9

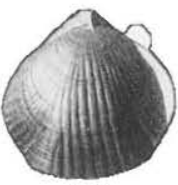

18

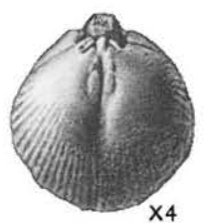

12

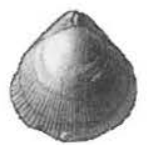

17

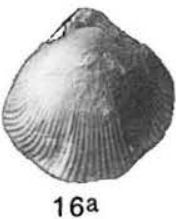

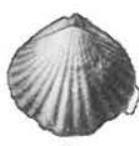

7
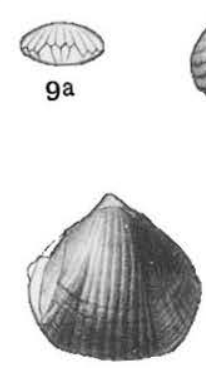

$18 a$

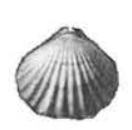

5

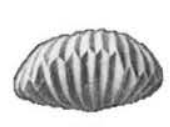

$4 a$

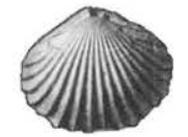

4

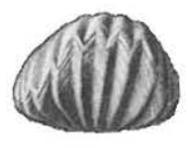

$3 a$
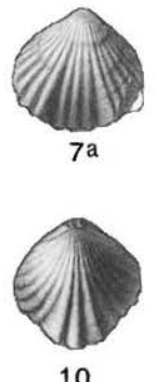

0
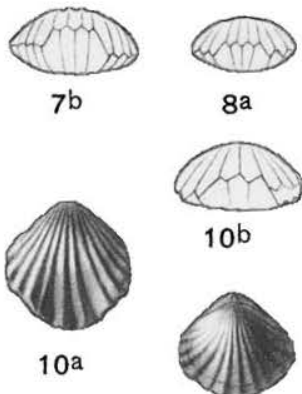

8
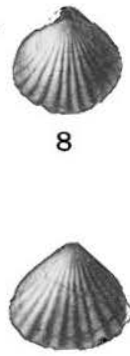

$11 \mathrm{a}$ 11

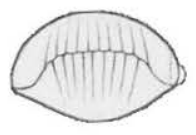

$18^{b}$

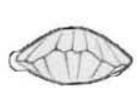

$11 \mathrm{~b}$

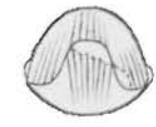

$14 \mathrm{a}$

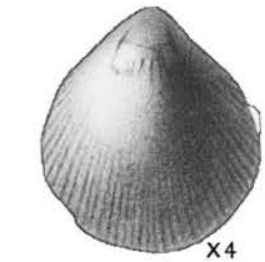

13

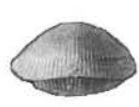

$17 a$
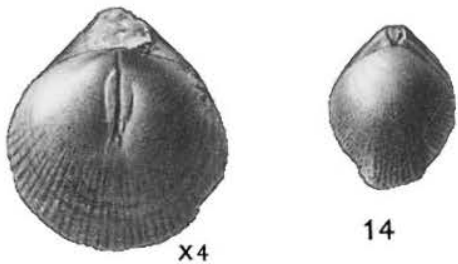

14
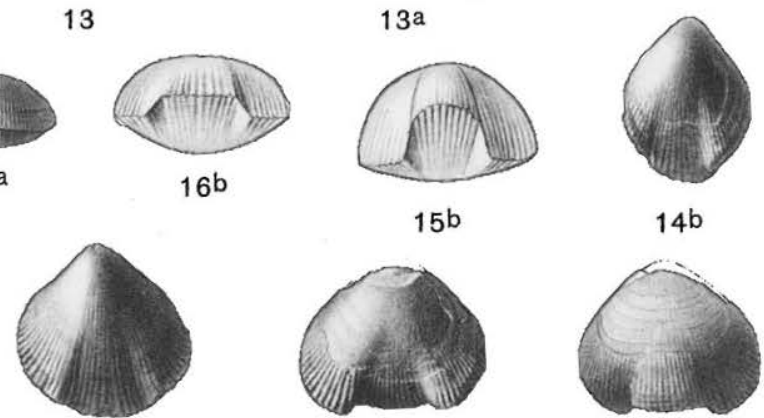

16

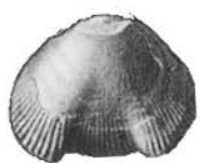

$14 b$

$15 a$

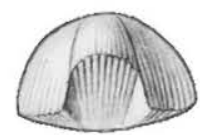

$15 \mathrm{~b}$

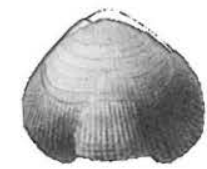

15

FAUNA OF THE MOOREFIELD SHALE 

MoOREFIELDELla EUREKensis (p. 63).

Figure 12. Dorsal view of a young specimen showing muscle scars, $\times 4$.

13. Ventral view of another young specimen, $\times 4$.

13a. Same, dorsal view.

Spring Creek, Ark. (station 1248A2).

14. Dorsal vew of a rare variety characterized by a narrow elongate shape.

14a. Same, anterior view in outline.

14b. Same, ventral view.

15. Dorsal view of a rare variety with transverse shape, high fold, and tumid dorsal valve.

15a. Same, ventral view.

15b. Same, anterior view in outline.

16. Ventral view of a characteristic specimen.

16a. Same, dorsal view.

16b. Same, anterior view in outline.

17. Dorsal view of a characteristic young specimen.

17a. Same, anterior view.

Spring Creek, Ark. (station 1248 Y).

MoOREFIELdELla EUREKENSIS var. subCuboides (p. 64).

Figure 18. Dorsal view of a unique specimen.

18a. Same, ventral view.

18b. Same, anterior view in outline.

Spring Creek, Ark. (station 1248Y). 

PLATE VI. 


\section{PLATE VI.}

\section{LIORHYNCHUS CARBONIFERUM (p. 54).}

FigURE 1. Ventral view of a large, well-preserved, and characteristic specimen.

1a. Same, dorsal view.

1b. Same, side view.

1c. Same, anterior view in outline.

2. Dorsal view of a smaller specimen.

3. Dorsal view of a narrow (probably slightly compressed) specimen with almost obsolete plications.

3a. Same, anterior view in outline.

$3 \mathrm{~b}$. Same, side view in outline.

3c. Same, ventral view.

4. A ventral valve with obsolete plications figured for comparison with a form from the Caney shale. $a$

5. An imperfect dorsal valve which has lateral ribs on the upper part but none on the lower.

6. A compressed dorsal valve with many mesial costæ. The upper portion shows a few lateral costæ which are not persistent. It is questionable whether forms like this should not be referred to $L$. carboniferum var. polypleurum.

7. An impression of a ventral valve flattened in shale.

8. Internal mold of a very small specimen retaining both valves in conjunction. Ventral view, $\times 5$.

8a. Same, dorsal view, $\times 5$.

9. Dorsal view of a young specimen referred to this species. Like the foregoing it is preserved as an internal mold, $\times 4$.

10. Dorsal view of a young specimen preserved as an internal mold in which two pairs of scars are fairly distinct, $\times 5$.

Spring Creek, Ark. The originals of figures 1, 2, and 5 are from station 1248Y; that of figure 3, from station 2048; that of figure 4, from station 2049; that of figure 6 from station 1248R4; those of figures 7, 8, 9 , 10, from station 1248A2. 
U. S. GEOLOGICAL SURVEY

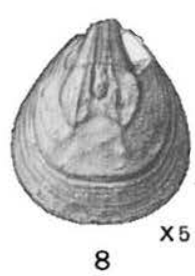

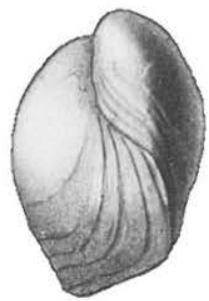

$1 \mathrm{~b}$
10

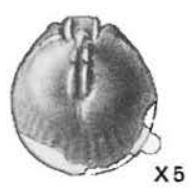

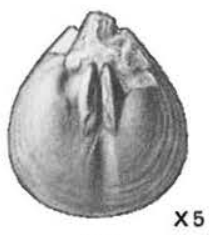

$8 a$
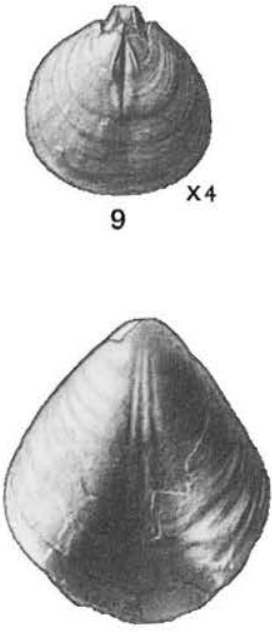

3c

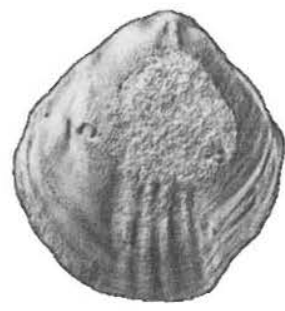

7

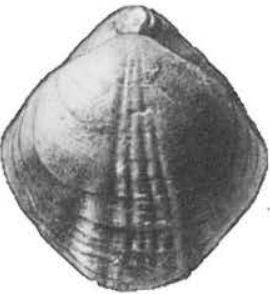

$1 \mathrm{a}$

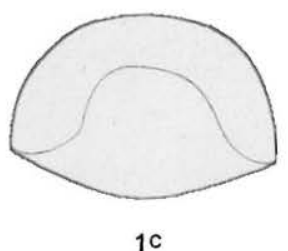

BULLETIN 439 PLATE VI

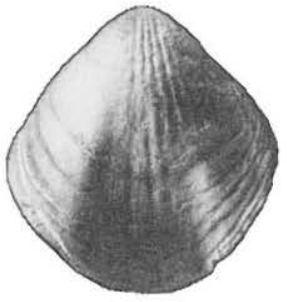

1
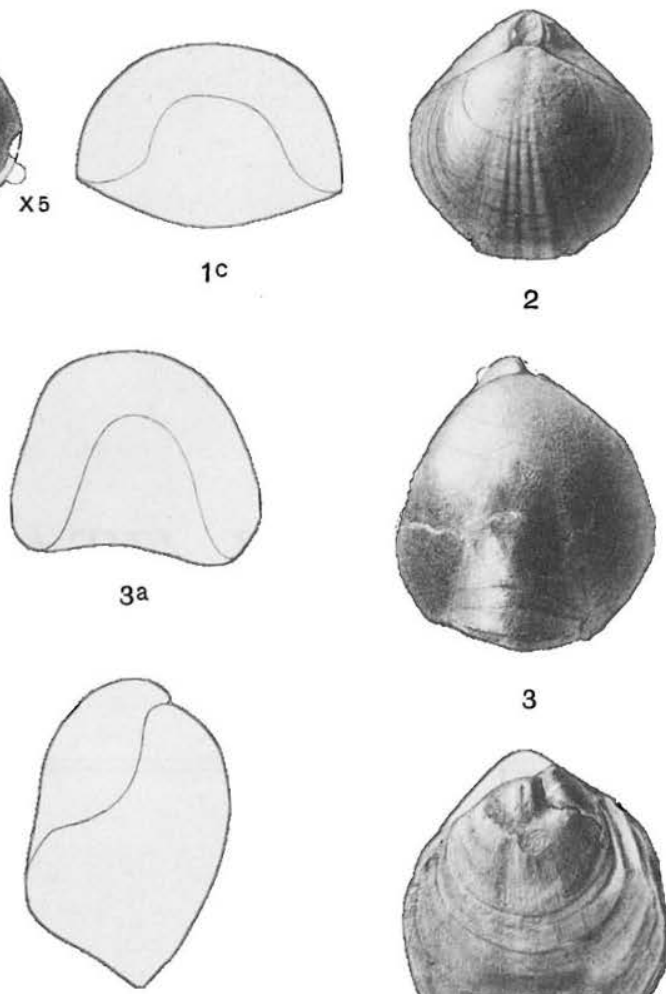

3

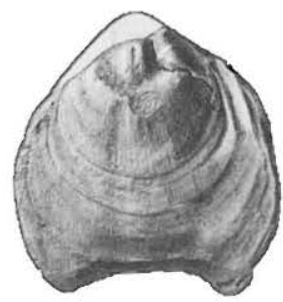

4

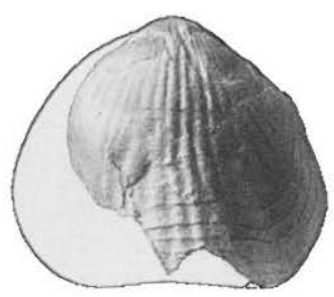

5

FAUNA OF THE MOOREFIELD SHALE 

PLĀTE VII. 


\section{PLATE VII.}

Bembexia nodimarginata (p. 91).

Figure 1. This and the three following figures are taken from McChesney and represent figures 1a, etc., of his Plate VII. Regarding these figures the descriptions of plates run as follows: "Figure 1, Pleurotomaria nodomarginata: $a, b, c$, views of three different individuals, and a portion of the surface magnified (the latter not lettered)."

2. After McChesney, being $1 \mathrm{~b}$ of his plate.

3. After McChesney, being 1c of his plate.

4. After McChesney, being the unnumbered figure of his plate.

Probably from the Moorefield shale at Spring Creek, Ark.

5. An imperfect specimen from the present collection, apertural view, $\times 2$. Spring Creek, Ark. (station 2048).

STROPHOSTYLUS aff.-CARLEYANUS'(p. 94).

Figure 6. A rather small specimen, viewed from the apical side, $\times 2$.

6a. Lateral view of the same, $\times 2$.

Spring Creek, Ark. (station 2049b).

LIORHYNCHUS CARBONIFERUM var. POLYPLEURUM (p. 59).

Figure 7. Internal mold of a dorsal valve, flattened in shale.

Spring Creek, Ark. (station 1248A5).

8. A poorly characterized dorsal valve of high convexity. The left side has three obscure costæ, while the right seems to be noncostate.

Spring Creek, Ark. (station 1248Y).

9. A small dorsal valve for comparison with a form from the Caney shale. $a$ Spring Creek, Ark. (station 2048).

10. Ventral view of a very young example.

Spring Creek, Ark. (station 1248A2).

11. A mold of a ventral valve flattened in shale. This shows the nonpersistent character of the lateral costæ.

Spring Creek, Ark. (station 1248A5).

12. Dorsal view of a young example, $\times 4$.

Spring Creek, Ark. (station 1248A2).

LIORHYNCHUS CARBONIFERUM (p. 54).

Figure 13. Internal mold of a very imperfect dorsal valve, showing muscle scars, $\times 1 \frac{1}{2}$.

Spring Creek, Ark. (station 2049).

14. Internal mold of an abnormal dorsal valve, which appears to have two septa. The specimen is much crushed, $\times 2$.

Spring Creek, Ark. (station 1248A5).

15. Internal mold of an apparently unplicated ventral valve, $\times 1 \frac{1}{2}$. Spring Creek, Ark. (station 1248R5).

16. Intermal mold of a dorsal valve with four costæ, showing internal markings, $\times 1 \frac{1}{2}$.

Spring Creek, Ark. (station 1248A2). 


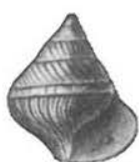

1

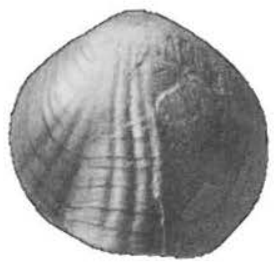

8

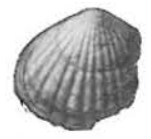

9

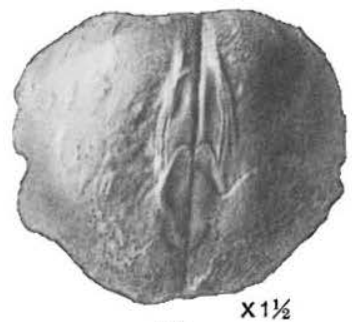

13

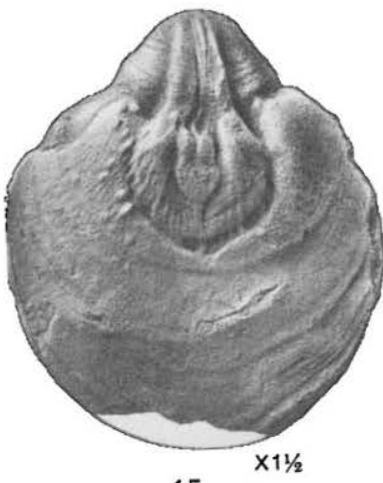

15

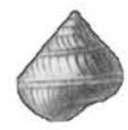

2
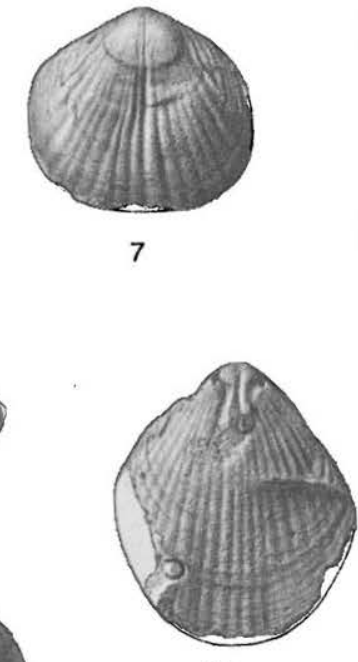

11

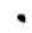

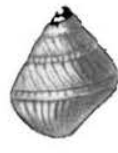

3

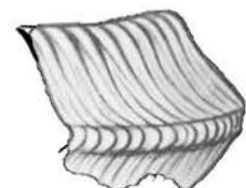

4
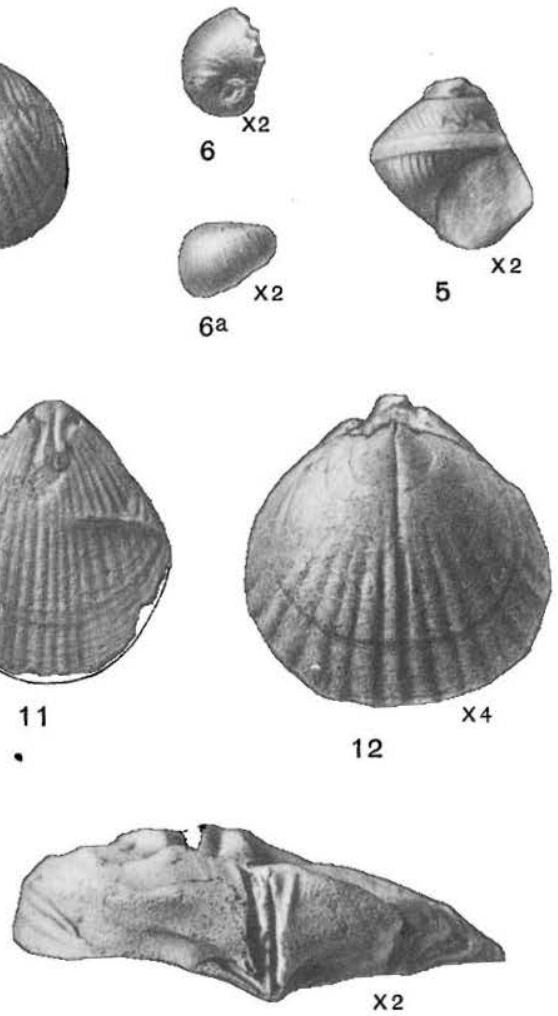

14

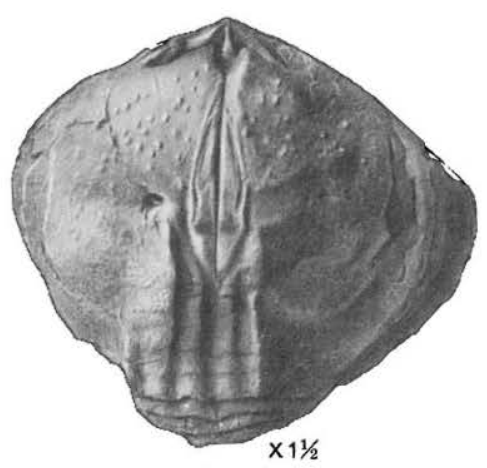

16

FAUNA OF THE MOOREFIELD SHALE 



\section{PLATE VIII.}




\section{PLATE VIII.}

\section{SPIRIFER MOOREFIELdiANUS (p. 68).}

Figure 1. An imperfect ventral valve.

Spring Creek, Ark. (station 2049a).

SPIRIFER ARKANSANUs (p. 66).

Figure 2. A medium-sized ventral valve.

Spring Creek, Ark. (station 1248Rx).

3. A large dorsal valve.

Spring Creek, Ark. (station 2049f).

4. A large ventral valve.

Spring Creek, Ark. (station 2048).

SPIRIFERINA SUBELliPTICA var. FAYETTEVILLENSIS? (p. 74).

Figure 5. An exfoliated dorsal valve.

Spring Creek, Ark. (station 2049a).

Reticularia Setigera (p. 69).

Figure 6. A large ventral valve in an imperfect state of preservation.

6a. Same, side view in outline.

Spring Creek, Ark. (station 2049a).

Ambocelia levicula? (p. 73).

FIGURE 7. A very small specimen preserved as an internal mold, dorsal view, $\times 5$.

7a. Same, ventral view, $\times 5$.

7b. Same, posterior view, $\times 5$.

$7 \mathrm{c}$. Same, side view in outline, $\times 5$.

8. A somewhat larger specimen, similarly preserved, ventral view, $\times 5$.

$8 \mathrm{a}$. Same, dorsal view, $\times 5$.

$8 \mathrm{~b}$. Same, side view in outline, $\times 5$.

8 c. Same, ventral view, $\times 2$.

9. A large specimen, ventral view, $\times 2$.

Spring Creek, Ark. (station 1248A2).

\section{EUMetria marcyi (p. 77).}

FIGURE 10. A rather coarsely costate dorsal valve. The sculpture is somewhat more coarse than that of typical $E$. marcyi and probably would not differ in this respect from young shells of $E$. vera var. costata of Hall.

Spring Creek, Ark. (station 2049b). 
U. S. GEOLOGICAL SURVEY

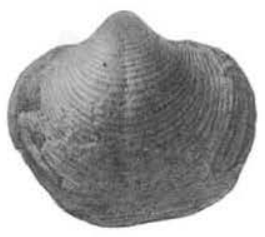

6

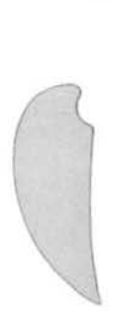

$6 a$

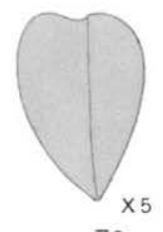

$7 \mathrm{c}$

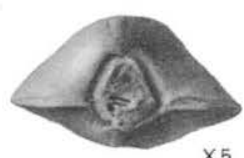

$7 \mathrm{~b}$

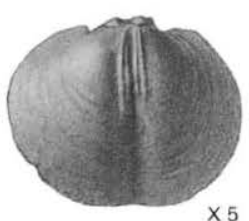

$7 a$

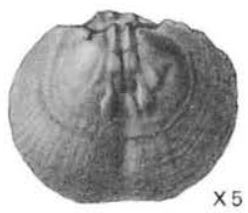

7

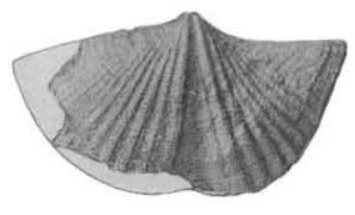

1

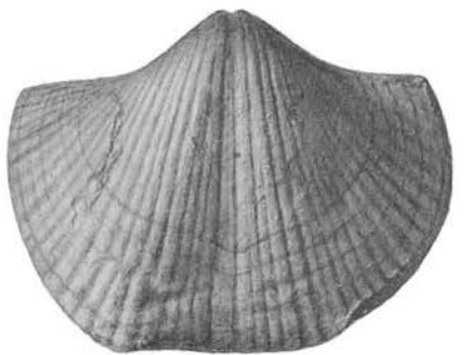

2

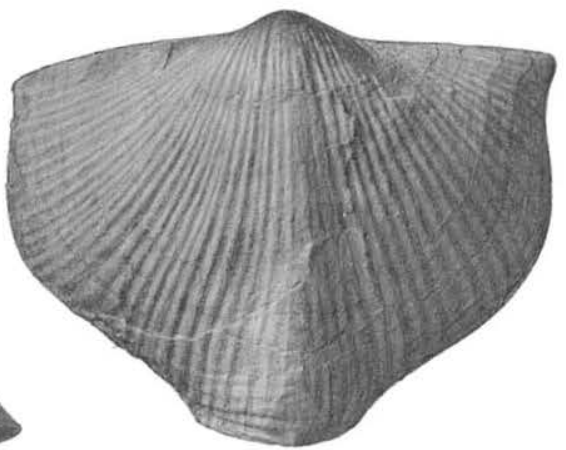

3

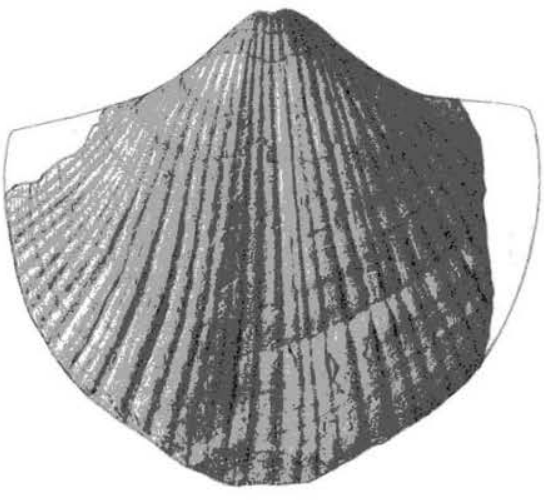

4

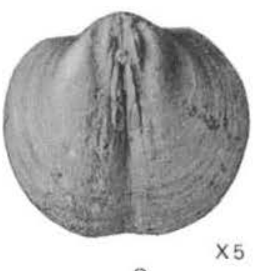

8

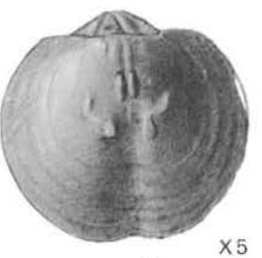

$8 \mathrm{a}$

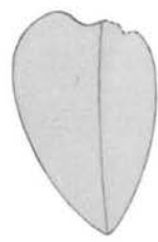

$8 b$

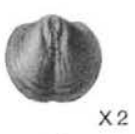

$8 c$

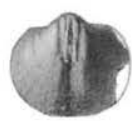

$9 \times$

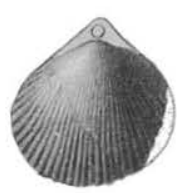

10

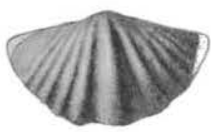

5

FAUNA OF THE MOOREFIELD SHALE 



\section{PLATE IX.}

,46447 - Bull. $439-11-9$ 


\section{PLATE IX. \\ Batostomella parvula (p. 30).}

FIGURE 1. Thin section showing cells cut longitudinally in the mature and immature regions, $\times 20$.

1a. Same, a tangential section, $\times 20$.

Spring Creek, Ark. (station 1248T).

Paraparchites nicklesi (p. 105).

Figure 2. A left valve, $\times 10$.

3. A larger left valve with differently placed spine.

4. A right valve, $\times 10$.

5. A smaller right valve, $\times 10$.

Spring Creek, Ark. (station 2048).

Primitia moorefieldana (p. 106).

Figure 6. A left valve, $\times 10$.

6a. Same, ventral view in outline (the upper end is posterior).

7. A right valve, $\times 10$.

7a. Same, dorsal view, $\times 10$ (the upper end is posterior).

Spring Creek, Ark. (station 2048).

\section{Martinia sp. (p. 72).}

Figure 8. A ventral valve reduced almost to an internal mold.

Spring Creek, Ark. (station 1248A2).

\section{MARTINIA GLABRA? (p. 70).}

Figure 9. A small ventral valve preserved in limestone and probably retaining the original convexity, seen from above.

9a. Same, view of the area.

9 b. Same, side view in outline.

Spring Creek, Ark. (station 1248R4).

10. A ventral valve preserved in calcareous shale and probably more or less flattened.

11. Another ventral valve somewhat flattened.

Spring Creek, Ark. (station 2049a). 

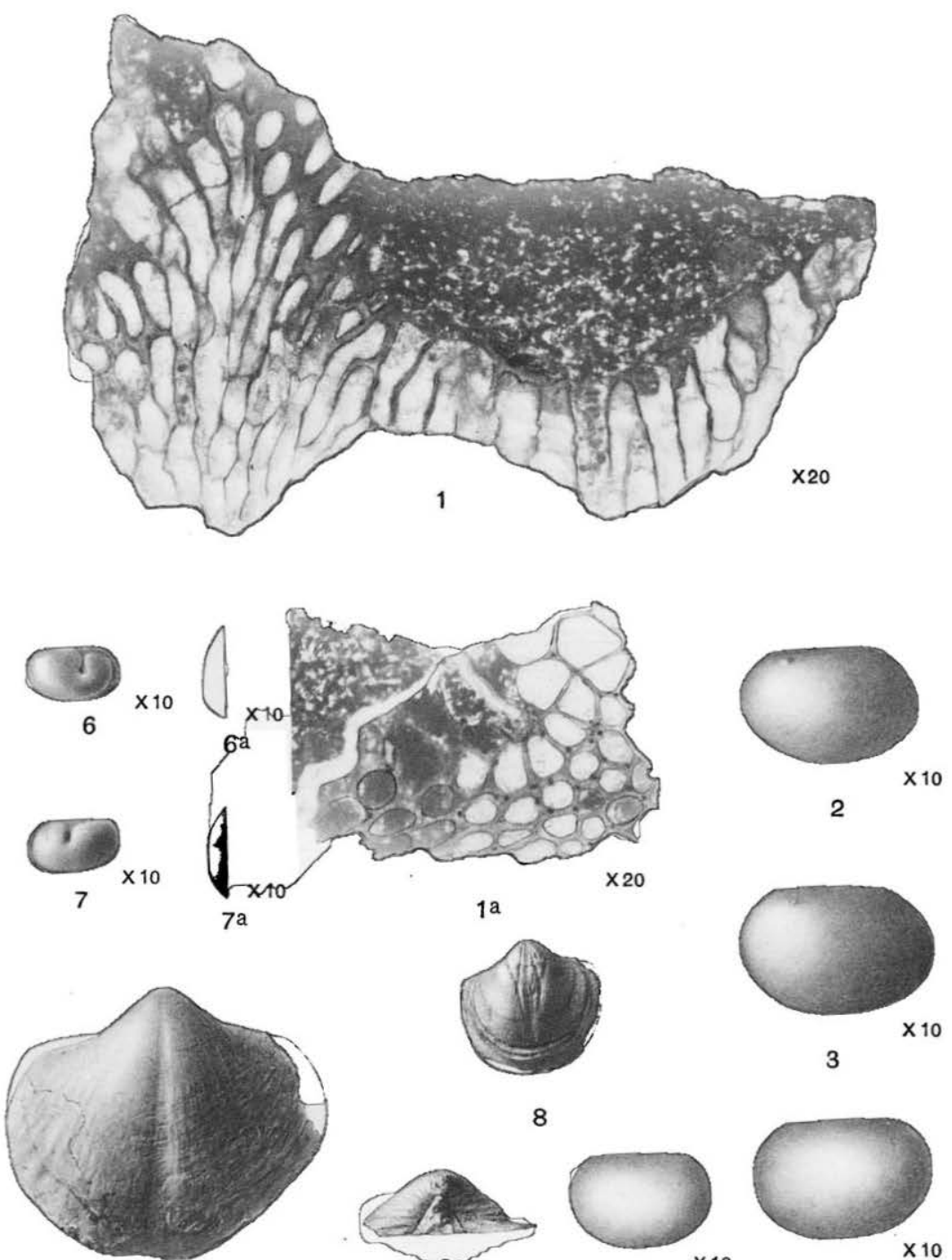

3

8
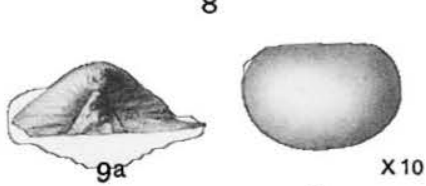

5

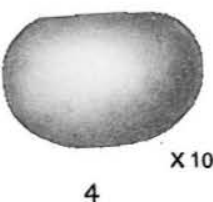

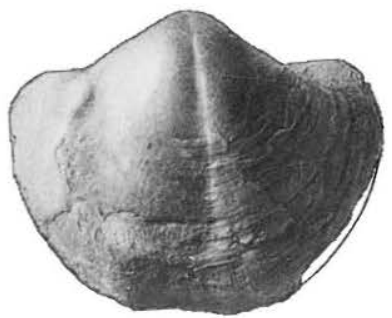

11

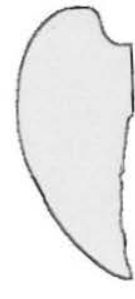

$9 b$

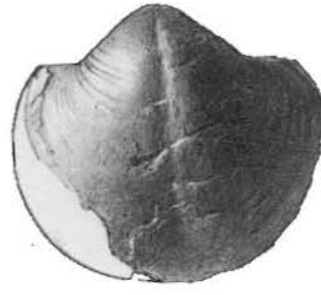

9

FAUNA OF THE MOOREFIELD SHALE 

PLATE $X$. 


\section{PLATE X.}

\section{Enchostoma BicaRinatum (p. 28).}

Figure 1. A block of limestone with several specimens, $\times 2$. White River Junction, Ark. (station 2053).

Batostomella dubia (p. 29).

FigUre 2. A tangential section through a branching specimen, $\times 20$.

Spring Creek, Ark. (station 1248T).

3. A section partly tangential and partly longitudinal through another specimen, $\times 20$.

Spring Creek, Ark. (station 2048). 

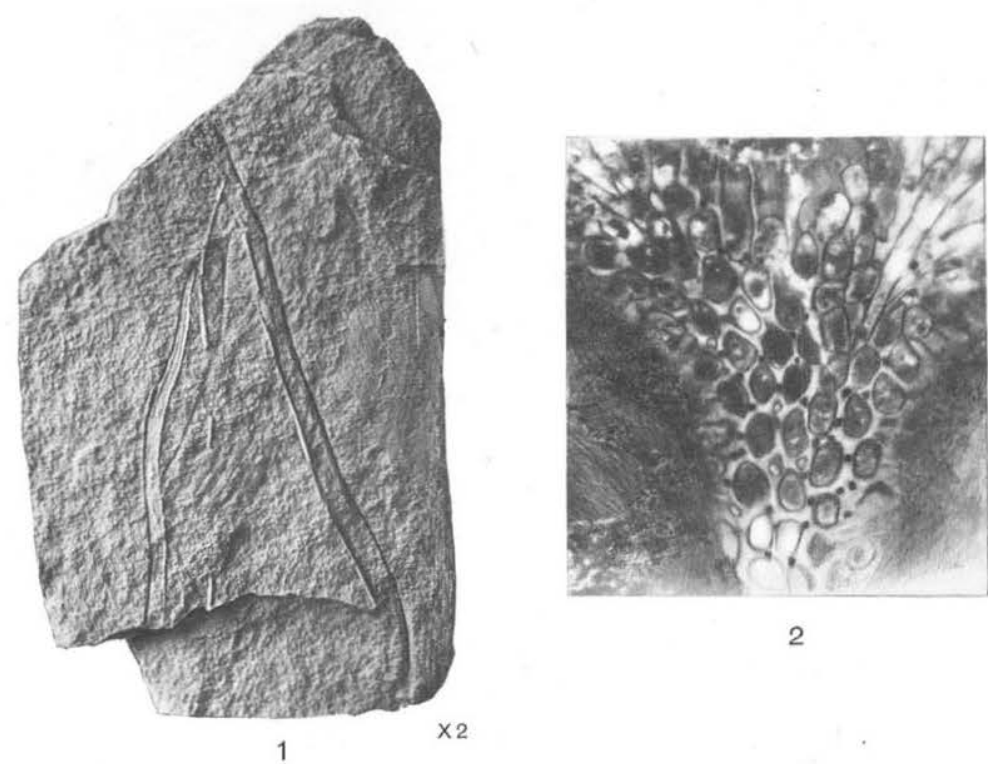

2

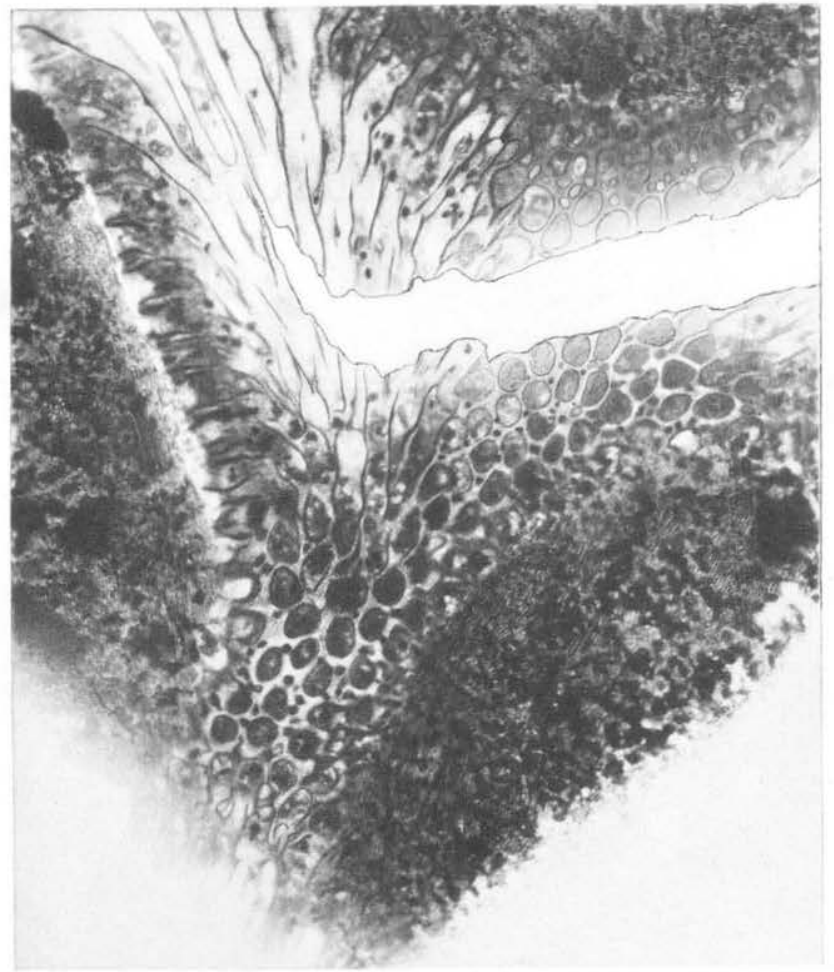



PLATE XI. 


\section{PLATE XI.}

\section{Deltopecten batesvillensis (p. 89).}

Figure 1. A small left valve from the "Spring Creek limestone."

Spring Creek, Ark. (station 1237R).

2. A left valve, somewhat deformed by compression.

3. A right valve, apparently somewhat malformed.

4. An imperfect left valve.

Moorefield, Ark. (station 2051b).

Deltopecten? sp. (p. 90).

Figure 5. An unidentified right valve.

Spring Creek, Ark. (station 2049a).

Leda nasuta? (p. 84).

Figure 6. A left valve preserved as an internal mold.

Spring Creek, Ark. (station 1248A2).

Leda. vaseyana (p. 83.)

Figure 7. The figures included under this number are copied from McChesney and represent figure 4 of plate 7 of his work. His description I quote as follows: " $a$, view of the cast of the interior of the right valve; $b$, left valve; $c$, right valve; $d$, outline enlarged."

Probably from the Moorefield shale at Spring Creek, Ark.

Caneyella nasuta (p. 87).

Figure 8. External mold of a specimen in which radiating costæ are nearly obsolete, $\times 2$.

9. A characteristic specimen.

9a. Same, $\times 2$.

Spring Creek, Ark. (station 2052a).

Caneyella percostata (p. 87).

Frauke 10. An imperfect right valve.

10a. Same, $\times 2$.

11. A nearly complete left valve.

11a. Same, $\times 2$.

Spring Creek, Ark. (station 2052).

Caneyella vaughani (p. 86).

Figure 12. Squeeze from a fragmentary specimen, which is, however, referred to C. vaughani with some confidence. Moorefield, Ark. (station 2051b). 
U. S. GEOLOGICAL SURVEY

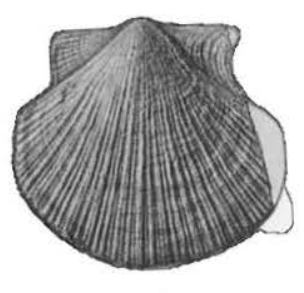

1

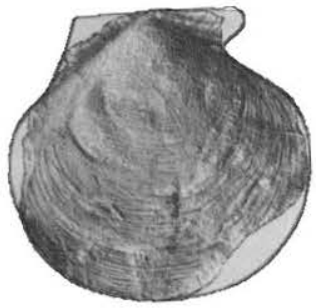

5
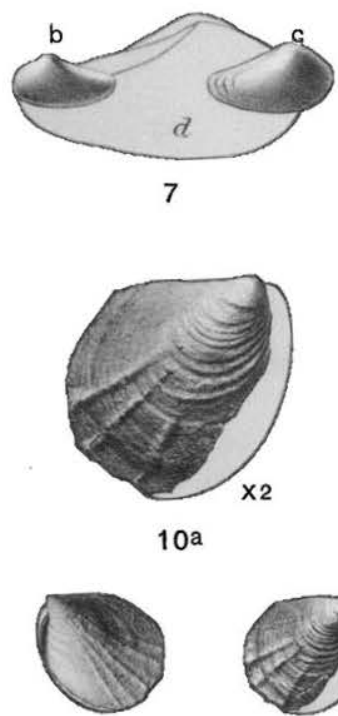

11

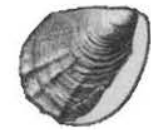

10

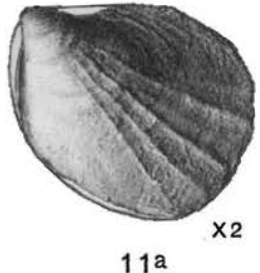

BULLETIN 439 PLATE XI
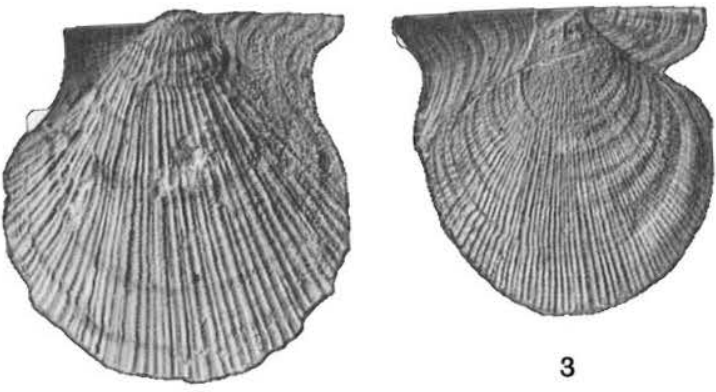

3

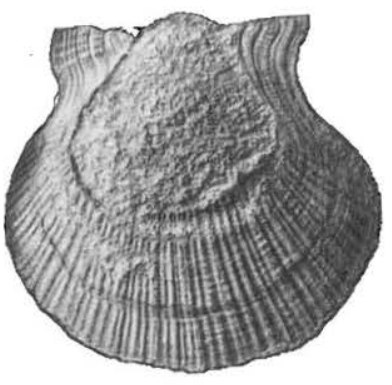

4

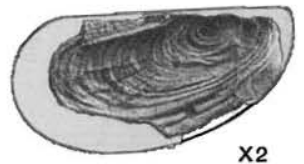

8
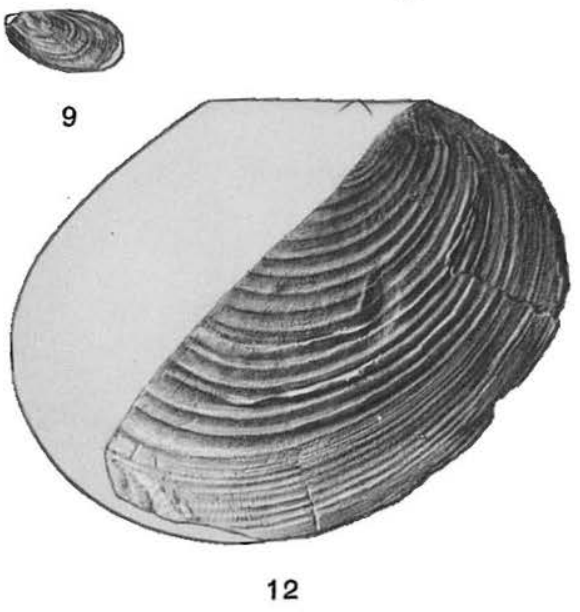

FAUNA OF THE MOOREFIELD SHALE 



\section{PLATE XII.}




\section{PLATE XII.}

CyPRicardinia? MOOREFIELdana (p. 85).

Figure 1. An imperfect right valve.

2. An imperfect left valve.

Both specimens are flattened in shale and their difference in shape may be due to that cause.

Spring Creek, Ark. (station 2049a).

Parallelodon multiliratus (p. 85).

Figure 3. An imperfect right valve with fine liræ, $\times 2$.

3a. Same, natural size.

Spring Creek, Ark. (station 2049a).

4. An imperfect left valve.

Spring Creek, Ark. (station 1248R).

Schizodus batesvillensis (p. 88).

Figure 5. A right valve referred to this species.

Spring Creek, Ark. (station 2048).

SPHenotus? sp. (p. 80).

Figure 6. An imperfect specimen of doubtful affinities. If it seemed justifiable to restore the shorter end as having the form of that in figure 7 both might be referred to the same species.

Spring Creek, Ark. (station 2049b).

Solenomya? sp. (p. 79).

Figure 7. An imperfect right valve.

Spring Creek, Ark. (station 1248T).

Edmondia CRASSA (p. 82).

Figure 8. A large right valve.

9. A small right valve, possibly a distinct variety.

Spring Creek, Ark. (station 2049b).

SPHENOTUS? MESLERIANUS? (p. 80).

Figure 10. A specimen doubtfully referred to this species.

- Spring Creek, Ark. (station 2049b).

Allerisma walkeri var. abbreviatum (p. 91).

Figure 11. A fairly perfect left valve.

Spring Creek, Ark. (station 2048). 
U. S. GEOLOGICAL SURVEY
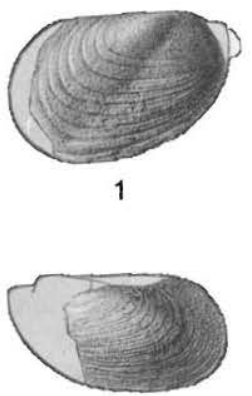

2

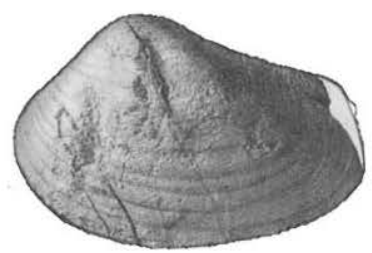

11
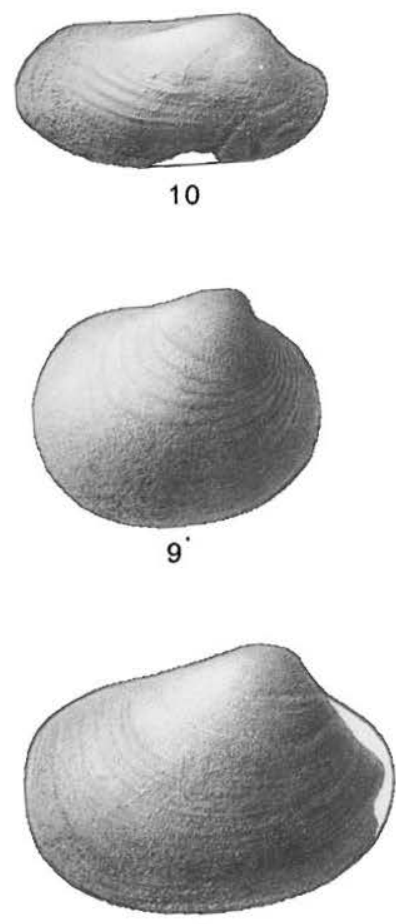

8

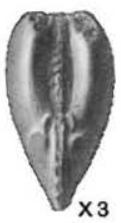

$13^{b}$
BULLETIN 439 PLATE XII

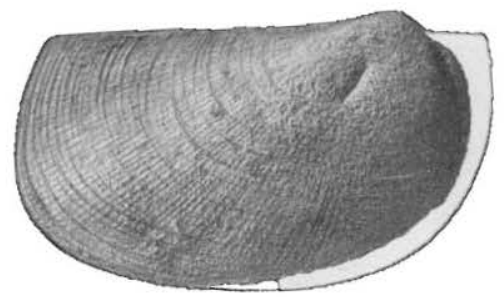

3

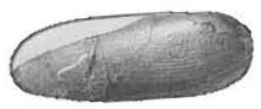

12
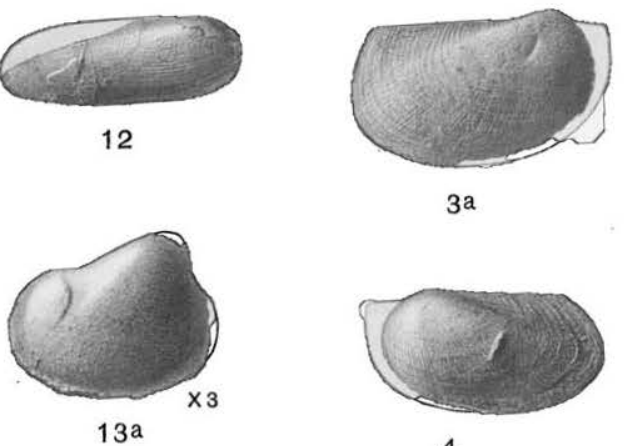

4

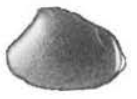

14
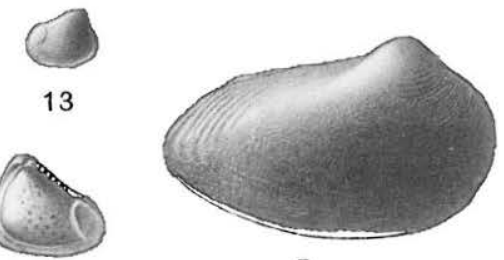

13

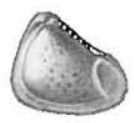

16

5
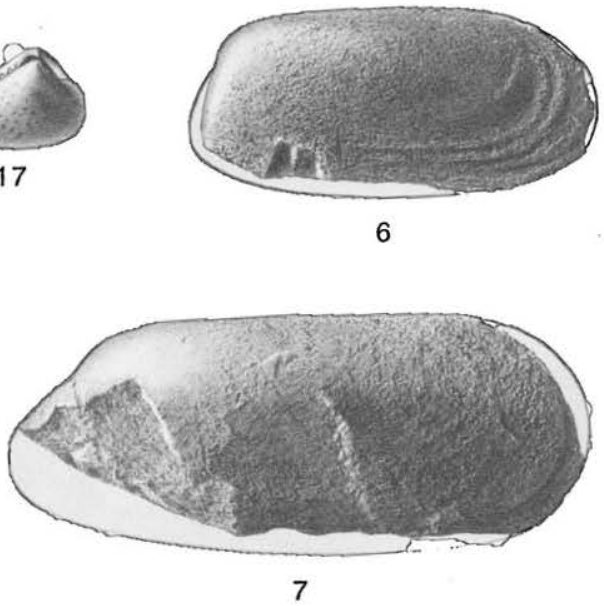

FAUNA OF THE MOOREFIELD SHALE 

SOLENOPSIS NITIDA? (p. 8 i).

Frgure 12. An imperfect right valve.

Marshall, Ark. (station 7039).

Nucula Rectangula (p. 82).

FIGURE 13. Left valve of a small specimen preserved as an internal mold.

13a. Same, $\times 3$.

13b. Same, view of the cardinal margin shewing two pairs of anterior muscle scars, $\times 3$.

14. A large imperfect right valve.

Spring Creek, Ark. (station 1248A1).

15. After McChesney, being figure $5 \mathrm{~b}$ of his plate 7 .

16. After McChesney, being figure $5 \mathrm{c}$ of his plate 7 .

17. After McChesney, being figure $5 \mathrm{a}$ of his plate 7. Of the last three illustrations McChesney says, in his description of plates, only " $a, b, c$, views of three distinct specimens."

Probably from the Moorefield shale at Spring Creek, Ark. 



\section{PLATE XIII.}




\section{PLATE XIII.}

Orthoceras sp. $a$ (p. 94).

FIGURE 1. A large, unidentified specimen, preserving only the living chamber.

1a. Part of the surface ornamentation, $\times 5$. Moorefield, Ark. (station 2051c).

\section{ENDOLOBUS ORNATUS (p. 95).}

Figure 2. Part of the living chamber. Dorsal view, looking down on the end of a septum.

2a. Same, ventral view.

2 b. Same, side view.

Moorefield, Ark. (station 2051c).

BaCtrites CARBonarius (p. 96).

Figures 3, 4, and 5. After Smith, being respectively figures 9, 10, and 11 of Plate VI of his monograph. $a$ These figures evidently represent views of three different specimens.

Moorefield, Ark.

140

$a$ Mon. U. S. Geol. Survey, vol. 42, 1903. 


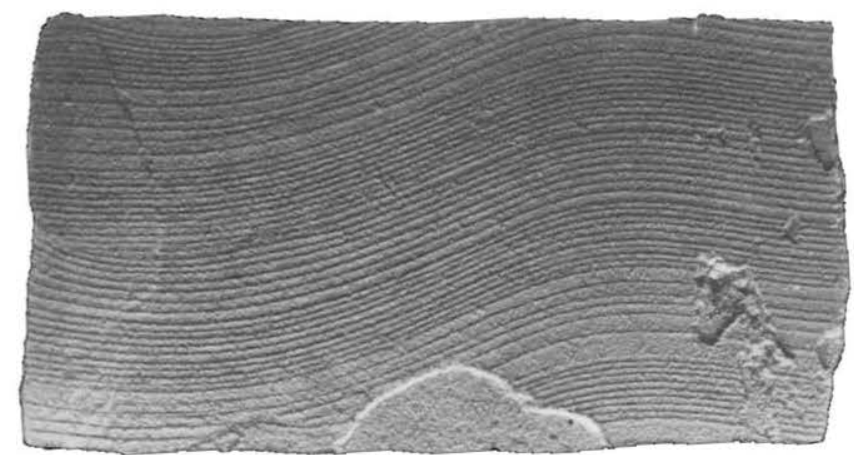

$1 a$
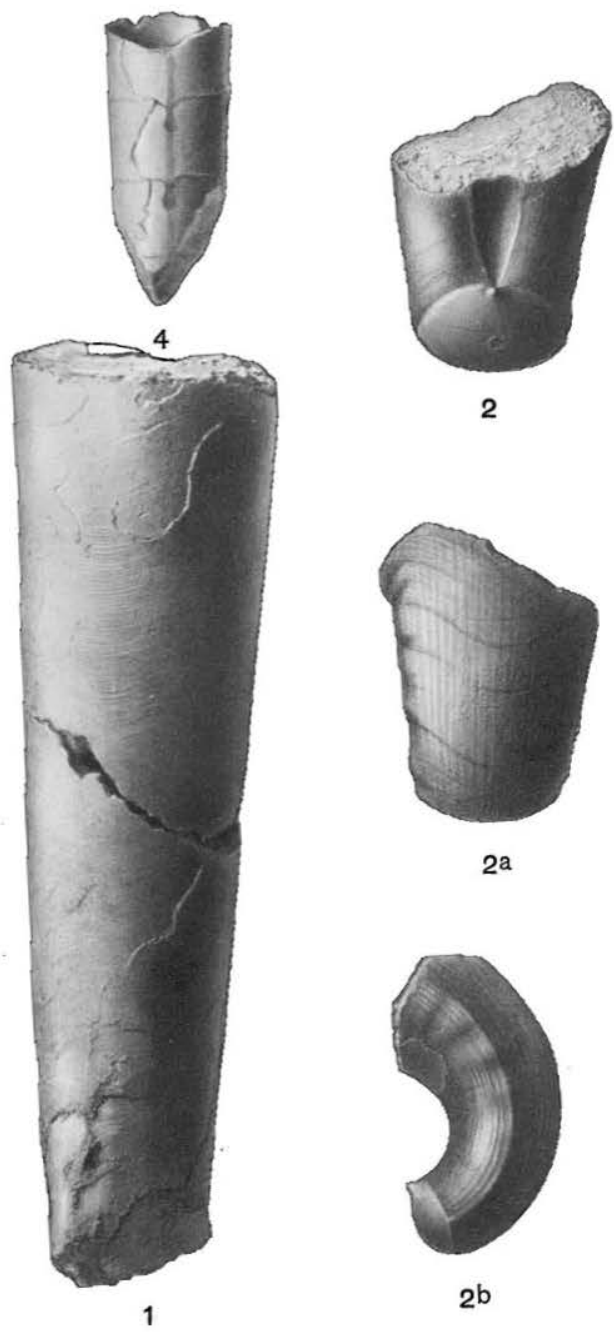

$\times 5$

2

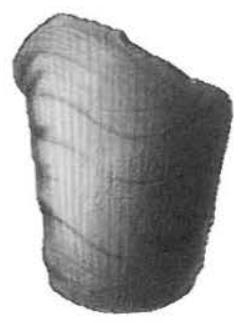

$2 a$
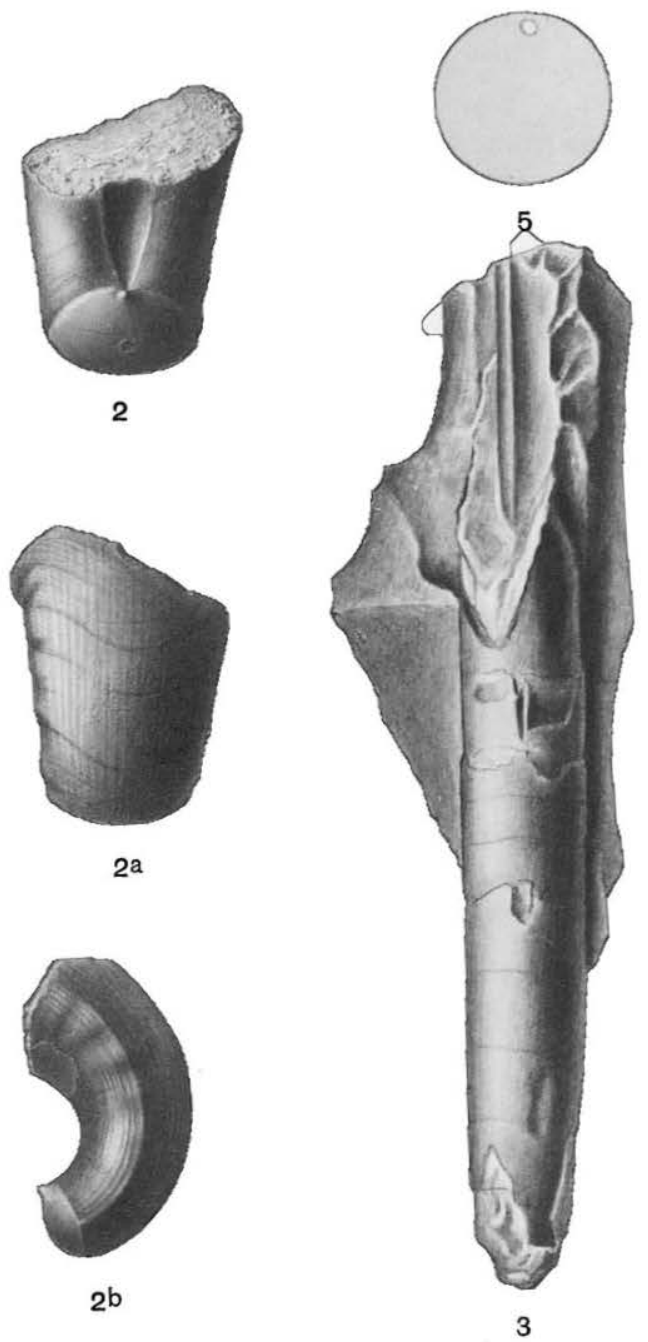

FAUNA OF THE MOOREFIELD SHALE 

PLATE XIV. 


\section{PLATE XIV.}

Goniatites Newsomi (p. 101).

Figure 1. Ventral view of a specimen, natural size, after Smith. $a$

la. Side view of same, after Smith.

lb. Inner coil of same, $9 \mathrm{~mm}$. in diameter, side view, $\times 3$, after Smith.

1c. Apertural view, $\times 3$, after Smíth.

"Batesville, Ark." (probably at Spring Creek).

Gastrioceras richardsonianum? (p. 102).

Figure 2. Side view of a specimen representing what Smith considers the mature stage; diameter $4.25 \mathrm{~mm}$., four and a half coils, $\times 5$, after Smith, $b$ reduced one-half.

2a. Apertural view of same, $\times 5$, after Smith, reduced one-half.

$2 \mathrm{~b}$. Suture of same, $\times 5$, after Smith, reduced one-half.

Smith's original figures are said to be ten times enlarged. The originals of figures 2 and $2 \mathrm{a}$ should then be $42.5 \mathrm{~mm}$. in diameter, whereas they are really $62.5 \mathrm{~mm}$. in diameter. I have no way of correcting this discrepancy.

3. Suture at late adolescent stage, transitional from Prionoceras to Glyphioceras; diameter $2.25 \mathrm{~mm}$., three and one-eighth coils, a little over six times enlarged, after Smith. A similar discrepancy exists in the case of this figure.

Moorefield, Ark.

Eumorphoceras Bisulcatum (p. 103).

Figure 4. Side view of a squeeze of a senile specimen.

Howards Wells, Ark. (station 1245a).

Adelphoceras MESLerIanum? (p. 104.)

Figure 5. A doubtfully identified specimen. Side view.

5a. Same, apertural view in outline.

5 b. Same, suture, $\times 2$.

Howards Wells, Ark. (station 1245a).

Gastrioceras Caneyanum (p. 102).

Froure 6. Side view of a large specimen.

Howards Wells, Ark. (station 1245B).

Goniatites SUBCIRCULARIS (p. 101).

Figure 7. Side view of a specimen, $\times 2$, after Smith.c

7 a. Same, apertural view in outline, $\times 2$, after Smith.

7 b. Suture of same, $\times 2$, after Smith.

8. Side view of a smaller specimen, $\times 3$, after Smith.

8a. Same, apertural view in outline, $\times 3$, after Smith.

"Batesville, Ark." (probably at Spring Creek).

$a$ Smith, J. P., Mon. U. S. Geol. Survey, vol. 42, 1903, pl. 17, figs. 2; 3, 4, 5.

$b$ Idem, pl. 18, figs. 8, 9, 10. 11. For embryonic stages see figs. 1-7.

cIdem, pl. 26, figs. 14-18. 
U. S. GEOLOGICAL SURVEY

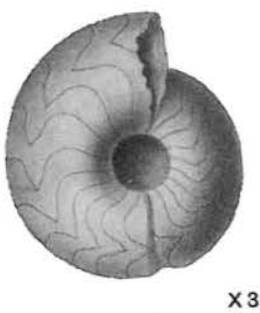

$1 \mathrm{~b}$

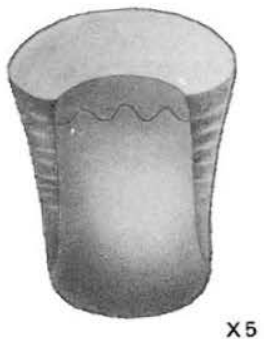

$2^{a}$

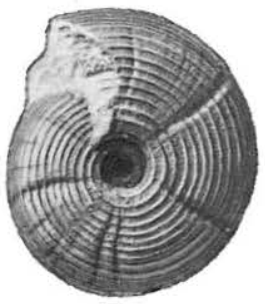

6

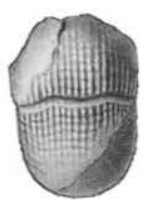

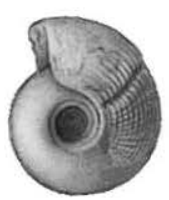

$1 \mathrm{a}$

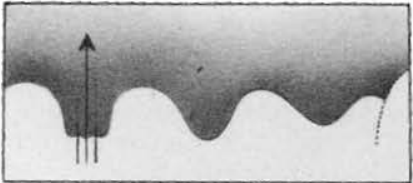

$2 b$

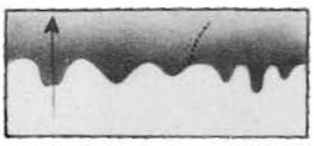

3

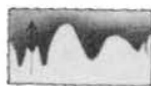

5 b $\times 3$

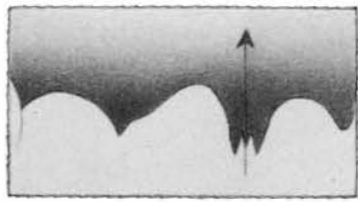

$7 \mathrm{~b}$

BULLETIN 439 PLATE XIV

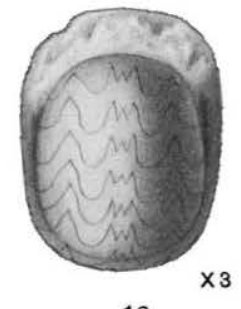

$1 \mathrm{c}$
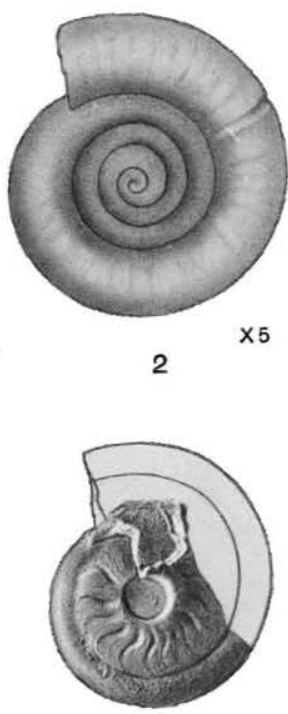

4

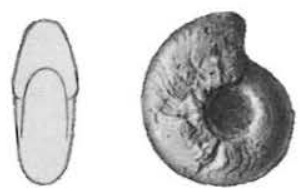

$5 a$

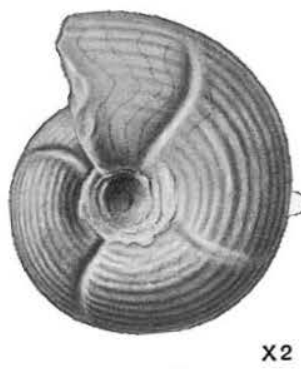

7.
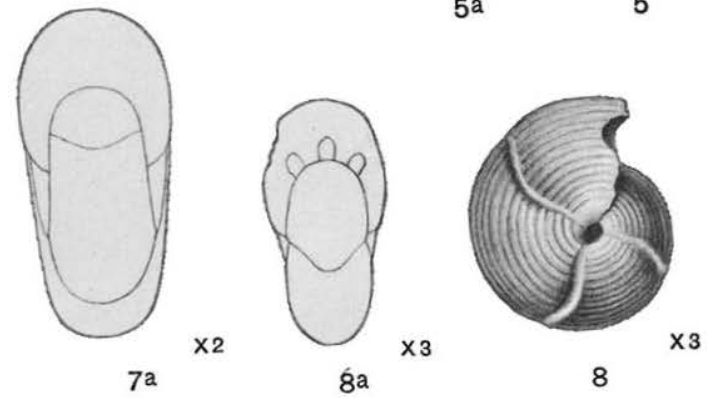

FAUNA OF THE MOOREFIELD SHALE 

PLATE XV. 


\section{PLATE XV.}

\section{Goniatites Choctawensis (p. 97).}

FIGURE 1. Side view of a young specimen $9.3 \mathrm{~mm}$. in diameter, $\times 5$, after Smith. $a$

1a. Apertural view of same, $\times 5$, after Smith.

A discrepancy exists somewhere here. If five times enlarged, the figures should have a diameter of $46.5 \mathrm{~mm}$., whereas in fact the diameter is but $36.5 \mathrm{~mm}$.

2. Side view of a young specimen having a diameter of $14 \mathrm{~mm}$., $\times 1 \frac{1}{2}$, after Smith.

3. Side view of adult specimen, natural size, after Smith.

3a. Apertural view of same, after Smith.

4. Adult external septa, enlarged, after Smith.

5. Internal septa, enlarged, after Smith.

6. Septa of a young specimen, $\times 2$, after Smith.

"Batesville, Ark." (probably at Spring Creek).

7. A specimen having a diameter of about $25 \mathrm{~mm}$. Surface (probably somewhat exfoliated) a little more than a volution younger than that shown by figure $7 \mathrm{a}, \times 3$.

7a. Surface, somewhat exfoliated, near the middle of the venter not far from the lip, $\times 3$.

Moorefield, Ark. (station 2051a).

\section{Goniatites crenistria (p. 99).}

Figure 8 . Side view of a specimen representing the early adult stage, $\times 1 \frac{1}{2}$, after Smith. $b$

8a. Same, apertural view in outline, $\times 1 \frac{1}{2}$, after Smith.

9. Septa, natural size, after Smith.

Moorefield, Ark.

$a$ Smith, J. P., Mon. U. S. Geol. Survey, vol. 42, 1903, pl. 26, figs. 6-13 (as G. striatus).

$b$ Idem, pl. 26, figs. 1-3. For illustrations of embryonic stages based on specimens from the Moorefield shale, see also plates 14,15 , and 16 .

144 
U. S. GEOLOGICAL SURVEY

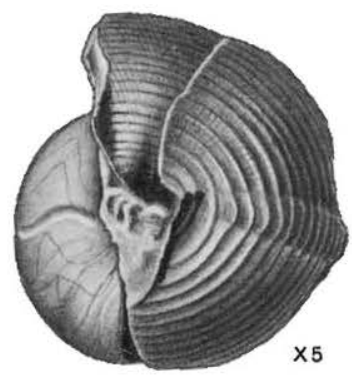

1

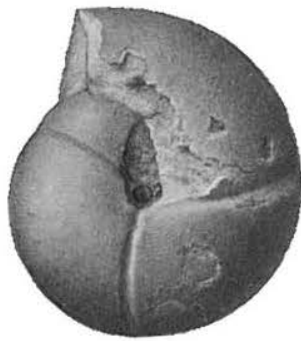

3
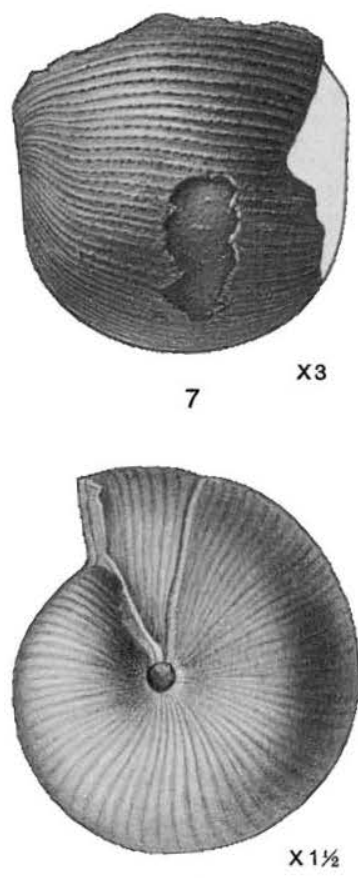

8

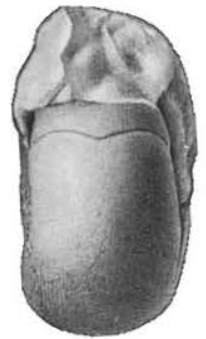

3a
BULLETIN 439 PLATE XV
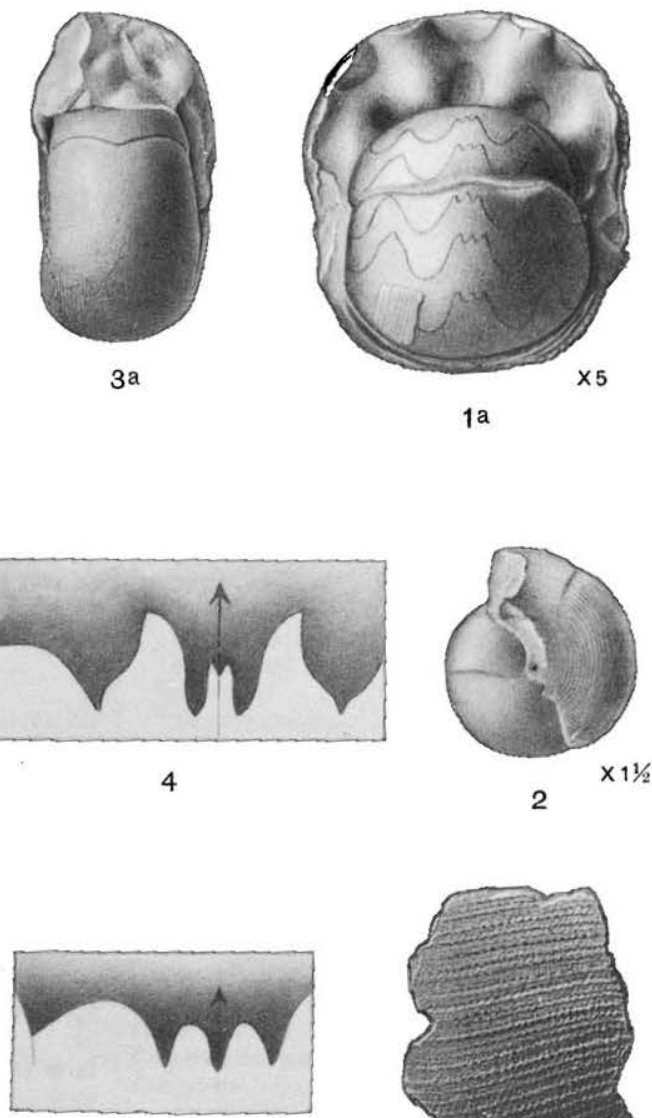

5

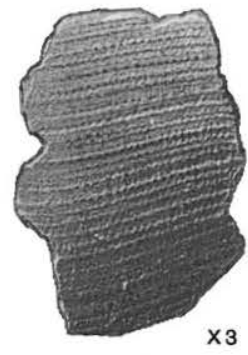

$7 a$

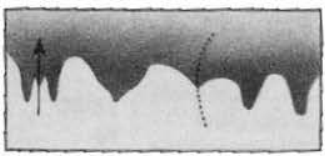

6

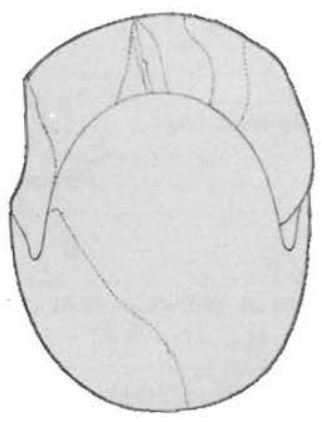

$8 a$

FAUNA OF THE MOOREFIELD SHALE 



\section{INDEX.}

Names in italic are synonyms; figures in itaiic denote illustrations; figures in black face denote descriptions.

\section{A.}

Actinoceras vaughanianum.

Adams, G. I., and Ulrich, E. O., fossils collected by.

Adelphoceras. meslerianum .............20,22,25,104-105, 148

Allerisma................................. 91

arkansanum........................... 91

cuyahoga............................. 91

walkeri.................................. 91

var. abbreviatum ........... 15, 22, 91, 136

Ambocœlia........................... 72, 73-74 lævicula.............. 12, 13, 22, 56, 72, 73-74, 128 minuta

Anomites glaber.

Asterocalamites scrobiculatus

Athyridæ.

A viculopecten batesvillensis.

\section{B.}

Bactrites carbonarius.... 17, 18, 22,95,96, 96-97, 140 quadrilineatus. smithianus.

Bactritidæ . $96-97$

Bairdia. attenuata.

$5,22,106$

Batesville, fossil localities at 29-31

Batostomella. abrupta.

dubia.. parvula.......... 14, 15, 16, 22,29, 30-31, 31, 130 nitidula spinulosa.

Batostomellidæ

Bellerophon

cancellatus.

textilis................................ 93 sp............................. 13, 15, 22, 93

Bellerophontidæ 93

Bembexia

91-92 nodimarginata.... 12, 13,14, 15, 17, 22, 91-92, 126 shumardi.

Beyrichiidæ............................. 106

Boonelimestone, character and occurrence of. 11-12

Brachiopoda............................ 32-79

Bryozoa................................... 29-32

Bucanopsis............................. 93

cancellata......................... 16, 22,93

textilis.

$6,22,93$
93
C.

Page

Camarotœchia...................... 20,60-65 purduei................ 16,22,60, 61,62,120 var. agrestis... 13, 14, 15, 16, 22, 60-61, 62, 120 var. laxa............21, 22,60, 61-62, 120

Caneyella............................. 86-88 nasuta................. 17,22,24,87-88, 134 percostata.................... 16,22,24,87, 134 richardsoni..... 24 vaughani................. 18, 22, 24,86-87, 134 wapanuckensis................. 21, 22, 24,87

Caney shale, fossils from .................. 24-27

Capulidæ............................... 94

Cephalopoda............................. 94-105

Chonetes............................... 41-42 flemingi............................... 41 illinoisensis............................ 41 planumbonus var. choctawensis......... 24 sericeus......................... 21, 22,41-42 sp.............................. 15, 16,22,42

Cliothyridina............................ 77

Colenterata............................ 28

Cœlonautilus gratiosus...................... 25

Composita.......................... 71, 75-77 humilis...................13, 15, 22, 77, 118 madisonensis var. pusilla...... 16, 22, 76-77, 118 subquadrata......................... $\quad 77$ var. lateralis.................... 13 , $14,15,16,22,71,75-76,77,118$ subtilita 77 sp................................... 24

Conocardium sp.......................... 24

Conularia................................ 28

Correlation, discussion of ................. 5-8 table showing....................... $7-8$

Cycloceras ballianum..................... ${ }_{25}$

Cypricardinia.............................. 85-86 moorefieldana.............. 14,16, 22, 85-86,136 Cypridæ................................. 106 Cyrtorizoceras hyattianum................. 25

Cytherella benniei......................... 25

\section{D.}

Deltopecten .......................... 18,89 batesvillensis .. 13, 15, 16, 18, 20, 22, 89-90, 90, 134 caneyanus.............................. 24 occidentalis......................... 90 sp ......................... 16,22,90,134

Diaphragmus.......................... 51-58 elegans.................. 13, 22, 23, 51-53,11є 


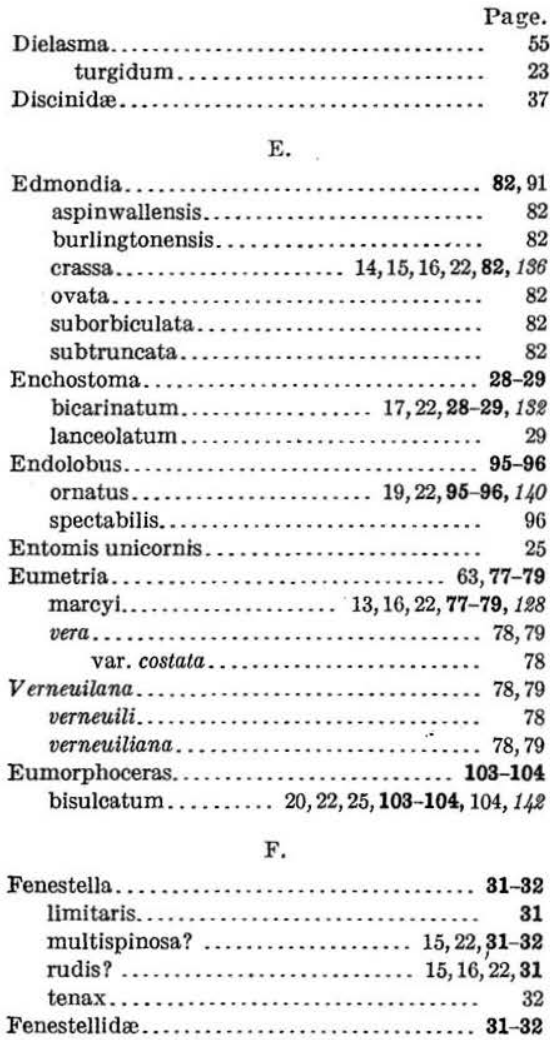

G.

Gastrioceras..............................102-103 caneyanum 16-17, 20, 22, 25, 101, 102, 102-103, 142 kingi .......................... 99, 100 richardsonianum.. 19, $22,25,99,100,101,102,142$ Gastropoda ......................... 91-94 Girty, G. H., fossils collected by ............ 15-17 Glyphioceras calyx .................. 19, 99, 102 cumminsi............................ 98

Glyphioceratidæ .................... 97-105

Goniatites choctawensis................. 12, $13,18,19,20,22,25,97-99,100,144$ crenistria............ 19, 22, 98, 99, 99-101, 144 incisum......................... 99, 100 newsomi............. 17, 22, 25, 101-102, 142 striatus.................. 17, 97, 98, 99, 100 subcircularis.............. 17, 22, 101, 102,142 sp................................. 25 Grammysiidæ......................... 82

Griffithides............................ 105 sp.......................... 16, 22, 105

H.

Harttina........................... 65-66 brevilobata.............. 13,22, 23, 65, 66,113 var. marginalis......... 13,22, 65, 66, 119 indianensis var. exporrecta.

Helmintha.
Howards Wells, fossils frome.

L.

Lævidentalium venustum..................

Leda ................................... 83-85 nasuta?................... 13, 22, 84-85, 194 polita............................. 83 vaseyana................ 17, 21, 22,83-84,134 Ledidæ................................ 83-85

Leiorhynchus papyracea.................. $\quad 58$ quadricostatus......................... 54,58

Leperditia nicklesi....................... 105 Leperditildæ............................. 105 Lingula..................... 20, 28, 32-37, 37 albapinensis ......... 13, $15,17,22,24,36-37,110$ anatina.......................... $33,34,35$ atra............................ 35, 36 batesvillæ ..... 13,14, 15, 16, 22, 32-36, 36, 37, 110 cuyahoga............................. 35,36 melie............................... 37 paracletus.......................... 24,36

Lingulidæ......................... 32-37 Lingulidiscina. . . . .................... 37-41 batesvillensis....................... 24, 39 herzeri............................ 39 newberryl var. caneyana.............. 14 $15,16,17,18,22,24,39,40-41,112$ var. marshallensis... 15, 20, 21, 22, 39-40,112 var. moorefieldana............... 13, $15,16,20,22,38-39,39,40,112$ var. ovata........ 12, 13,17, 22, $24,40,118$ Liorhynchus..... 15, 18, 20, 21, 54-60,62, 64, $71,74,75$ boonense......................... 58 carboniferum........ 12, 13, 14, 15, 16, 17, 18, 20, $21,22,23,24,54,59,60,62,64,71,75,124,126$ var. polypleurum............... 12 , $13,14,15,20,21,22,24,59-60,62,626$ greenianum........................ 58 haguei............................... 58 laura............................ 24, 59,60 mesicostale...................... 24,54,57,60 multicosta............................ 60 papyraceum ........................ $\quad{ }_{59}$ papyraceus.......................... $58-59$ quadricostatum.................... 58

Localities, register of .................. 107-108 M.

Macrochellus micula........................ 24 sp................................ ${ }^{24}$

Macrodon............................. 86 hamiltoniæ......................... 86 ovatus............................. 86 Marshall, fossils from................. 20-21,22 section at........................... 20

Martinia...................... 70-73,74, 75 contracta.......................... $\quad 23$ glabra........................ 13 , $14,15,16,17,22,23,70-72,72-73,75,76,190$ sp .............. 13,14,15, 16,22, 24, 72-73,150 Martiniopsis............................ 71 McChesney, J. H., fossils determined by..... 17 Menophyllum............................ 28 sp............................ 16,22,28 Moorefield, fossils from.................... 17-19,22 
Page.

Moorefieldella................ 15, 62-65, 74 eurekensis..................... 12,13,14,15, $16,17,21,22,23,56,62,63,(63-64), 121$ var. subcuboides......... 14, 22,64-65, 121

Moorefield shale, description of............. 22-24 fossils of, table........................ 22

N.

Naticopsis sp.

Nomenclature, discussion of ............... $5-8$

Nucula................................ 82-83 nasuta............................. 84 rectangula............. 12,17, 21, 22, 82-83, 187

Nuculana nasuta......................... 84 Vaseyana . ........ 83

Nuculidæ............................ 82-83

Nuculites vaseyana..................... 17,83

O.

Oehlertella ............................. 37, 38

Orbiculoidea................................ 37,38

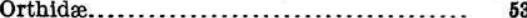

Orthoceras caneyanum...................... 25

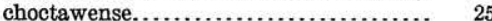
crebriliratum................ 13,16, 22, 25, 94 indianum............................ 25 wapanuckense....................... 24 sp................ 17, 18, 19, 22, 25,94-95, 140 Orthoceratidæ. 94-95

Ostracoda.

105-106

\section{P.}

Parallelodon......................... 85, 86 multiliratus......... 14, 16, $17,22,24,85,86,186$ newarkensis......................... 85 truncatus........................... 85

Parallelodontidæ........................ 85-86

Paraparchites........................... 105 nicklesi.................... 15, 16, 22, 105, 180

Pectinidæ........................... 89-90

Pelecypoda................., $\ldots \ldots \ldots \ldots \ldots \ldots, 79-91$

Pholadellidæ............................ 91

Pleurophorus............................ 80,81 costatiformis.......................

subcostatus.......................... 81 taffi................................ washingtonensis..................... 81

Pleurotomaria nodimarginata............. 17,22,91 nodomarginata......................... 91 sulcomarginata.......................... 99 sp .............................. 19,21,24

Pleurotomariidæ....................... 91-92

Primitia................................... 106 fayettevillensis...................... 106 granimarginata...................... 106 moorefieldana ..................15,22, 106, 180 subæquata........................... 106

Productella...................50-51 hirsutiformis.................... 12,13,14, $15,16,17,21,22,23,24,45,46,47,50-51,116$ var. batesvillensis............ 16, 22, 51, 116

Productidæ........................... 41-58

Productus.......................... 42-53, 56 adairensis......................... 51 arkansanus var. multiliratus..... 14, $22,43,112$ biseriatus...........13,15, 16, 22, 46-47, 49,116 boliviensis. concentricus. . . . . . . . . . . . cora ................................ coræformis............................. elegans.............................. 51,52 indianensis....................... 47, 49,50 inflatus........................... 42 var. coloradoensis?.. 14, 15, 16, 22, 42-43, 118 lævicosta........................... 44 moorefieldanus...................... 13 $14,15,16,22,48,48-49,49,50,116$ var. pusillus......... 13,15, 22, 49-50, 116 pileiformis........................ 13, $14,15,16,17,20,22,24,44-46,51,118$ semireticulatus..................... 42, 43 setiger.............................. 43 subsulcatus...... 12,13,15, 22, 47, 48, 49, 50,116 var. janus............ 13, 15, 22, 48, 49, 116

Proetidæ............................. 105

Protowarthia.......................... 93

Pteriidæ......................... 86,

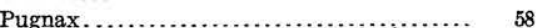
missouriensis....................... 58

\section{R.}

Reticularia......................69-70, 72, 75 pseudolineata........................ 23 setigera............. 15, 16, 22, 23, 69-70,71, 128 setigerus............................. 69

Retzia Marcyi.......................... 78 radialis............................. $\quad 78$ vera............................... 78 var. costata Verneuilana.......................... $\quad 78$ verneuilana........................... 78

Rhipidomella........................... 53 arkansana.................. 15, 16, 22, 53, 113 burlingtonensis........................ 53 clarkensis........................... 53 dubia................................ 53 oweni................................ 53

Rhombopora........................ 30 Rynchonella (Leiorhynchus) papyracea ..... 58 Rhynchonellidæ...................... 54-65 Riversdale beds, fossils of ................ 26-27

S.

Sanguinolites........................... 81 sp................................ 81

Schizodus ........................... 88, 91 batesvillensis ............. 15, 21, 22,88, 91, 136 Schizotreta............................. 37 Seminula humilis....................... 77 madisonensis var. pusilla ............... 77

Smith, J. P., fossils determined by .......... 17-18

Solenomya............................ 79-80 anadontoides......................... 80 parallela............................ 80 soleniformis ............................ 80 sp $\ldots \ldots \ldots \ldots \ldots \ldots \ldots \ldots \ldots \ldots \ldots \ldots \ldots \ldots \ldots, 22,79-80,136$ Solenomyacidæ............................. 79-80 Solenopsidæ........................... 80-81

Solenopsis............................ 81 nitida .................... 13,21, 22,81, 187

Sphenotus.......................... 80, 80-81

Sphenotus meslerianus........... $16,22,80,81,186$ sp ...................... 15, 22, 80-81, 186 


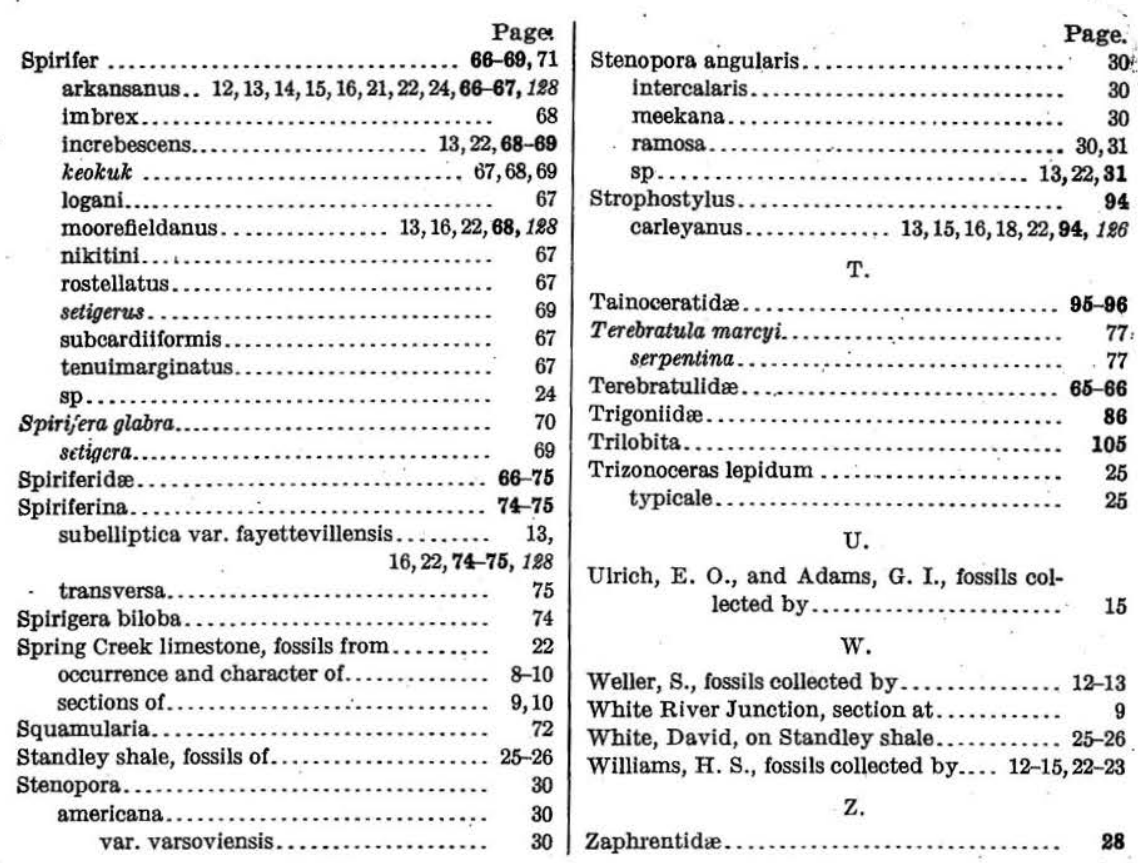




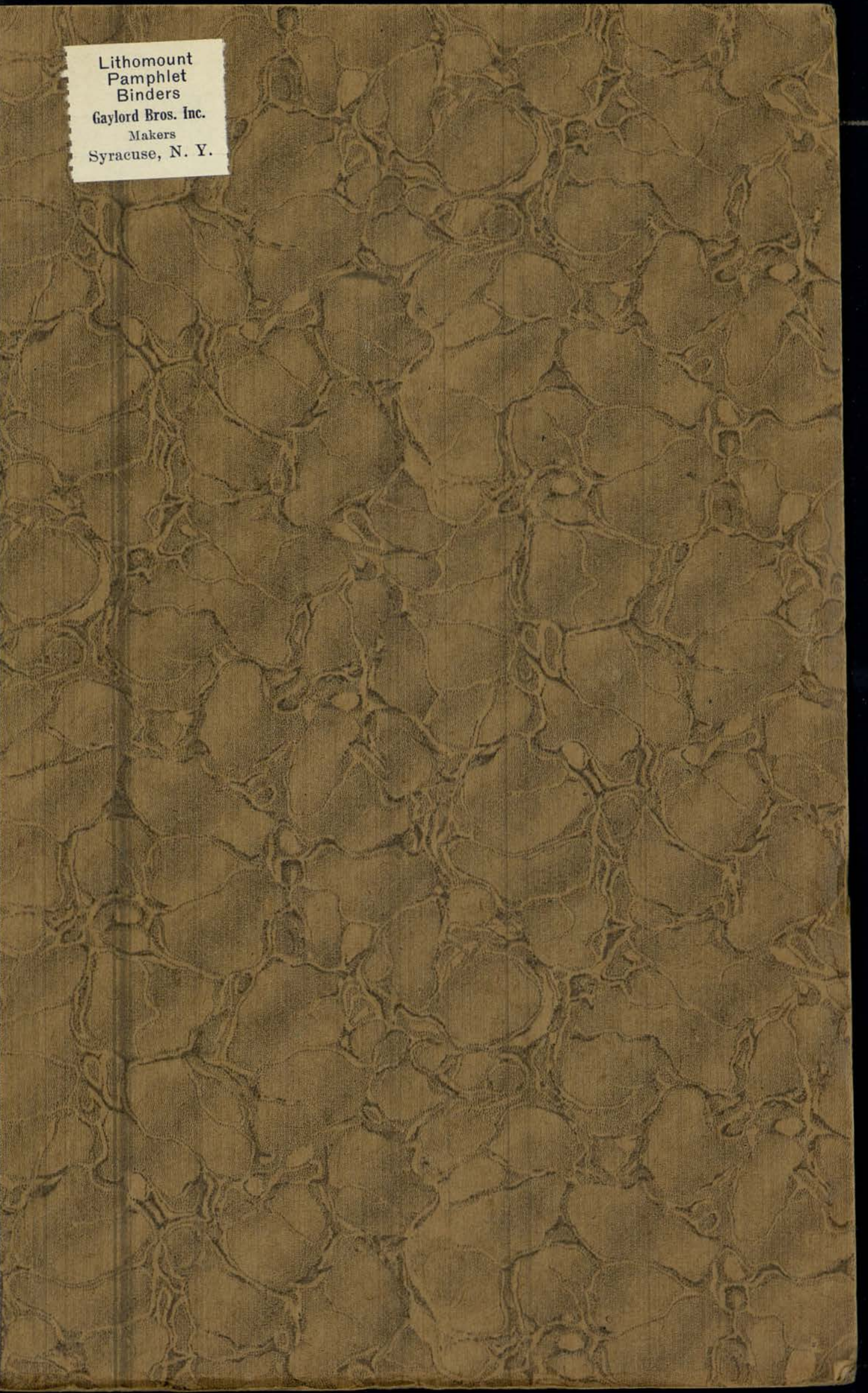




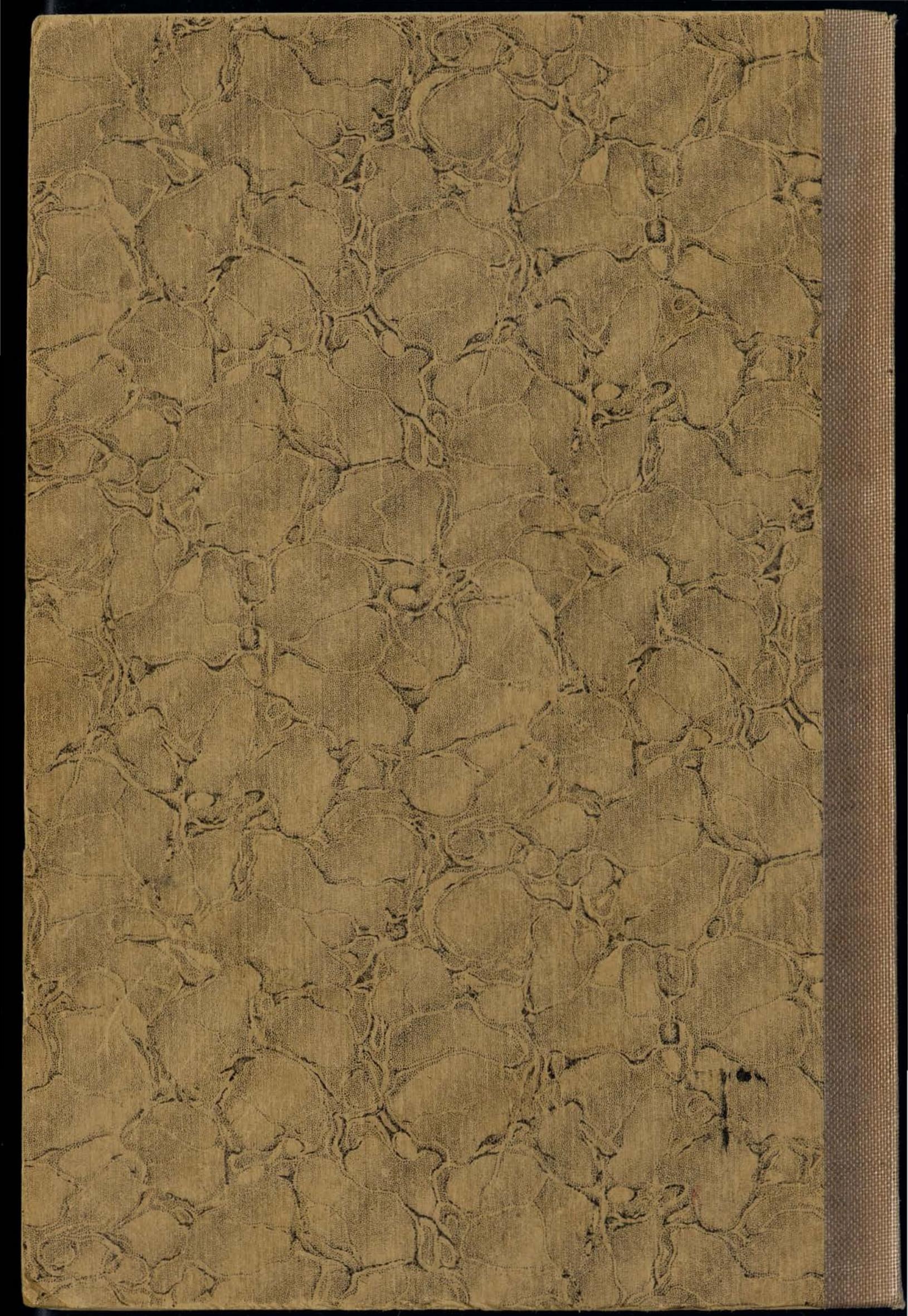

